\title{
PROJECT COMPLETION REPORT
}

\section{PROBLEMS OF PUBLIC ACCESS TO WATER IN TEXAS LAKES AND STREAMS: AN ANALYSIS}

by

Otis W. Templer

Department of Geography

Texas Tech University

OWRT Project No. A-042-TEX Matching Grant Agreement No. TT-76-1

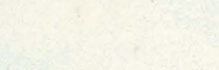

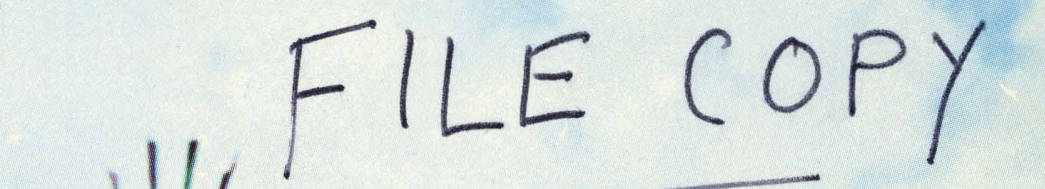


PROBLEMS OF PUBLIC ACCESS TO WATER IN TEXAS

LAKES AND STREAMS: AN ANALYSIS

\author{
By \\ Otis W. Templer, J.D., Ph.D. \\ Professor of Geography \\ Texas Teeh University \\ tubbock, Texas
}

Project Number A-042-TEX

The work upon which this report is based was supported by funds from the Texas Water Resources Institute, Texas A \& M University, Allotment Program, provided by the Office of Water Research and Technology, United States Department of the Interfor, as authorized under the Water Resources Research Act of 1964, as amended.

\author{
Technical Report \\ Prepared for \\ Texas Water Resources Institute \\ Texas A \& M University
}

October 1978 
This report examines the problems surrounding public access to the state-owned waters of Texas' lakes and streams, surely one of the most poorIy understood areas of water and property law. Limited access to public water resources is becoming an increasingly serious problem as the state's rapidly growing populace seeks to avail itself of water-based recreational opportunities. The development of water and land law relating to public access is reviewed. Texas * complex water law history, combining diverse Hispanic-Anglo elements, along with the general absence of public land, make comparisons with other furisdictions difficult.

Unlike Gulf coastal waters and beaches, there is no express statutory recognition of the right of public access to inland waters. However, a number of cases do recognize this right for a variety of purposes; but because most of the law turns on the unique fact situations of each case, it is impossible to develop generally applicable legal principles. The problems of determining navigability and stream bed ownership in the context of Texas' statutory definition are reviewed, as are the even more tenuous rights of public use of banks and shores of navigable waterways.

Once public access is attained, numerous impediments such as fences, dams, etc., often confront the would-be recreationist. Such obstacles are illustrated and discussed, as are the spatial aspects of access sites. Finally, unsuccessful alternatives which might have solved some of the recurrent problems are examined. Short of currently unacceptable comprehensive legislation, there are few measures to help resolve the growing controversy between the recreation-seeking public and private landowners in Texas. KEY WORDS: Water Law, Water Rights, Public Access to Water, Navigability, Stream Beds, Public Use of Banks and Shores, Spatial Aspects of Public Access, Texas. 


\section{ACKNOWLEDGEMENTS}

This study was supported by the Office of Water Research and Technology, through the Allotment Program of the Texas Water Resources Institute, Texas A\& M University, in cooperation with Texas Tech University. The financial support provided by Project Number A-042-TEX is gratefully acknowledged. The author wishes to express his particular appreciation to Dr. Jack R. Runkles, Director of the Texas Water Resources Institute, for his encouragement and graclous support during the duration of the project. The late Dr. Dan M. Wells and Dr. Robert M. Sweazy, Director of the Water Resources Center at Texas Tech University, both gave helpful advice in the initial preparation of the proposal leading to the project. Dr. Sweazy also provided invaluable assistance during the final stages of preparation and publication of this report.

I am most indebted to the personnel of the various water and recreation agencies with whom I consulted during this research, especially those employed by the Texas Department of Water Resources. The staff of the technical library of the Texas Department of Water Resources in Austin, Texas provided willing assistance in locating data and source materials. Also, the staffs of the University Library and the Law School Library at Texas Tech University were particularly helpful in aiding the author to secure needed materials. Finally, the support of the Department of Geography at Texas Tech University for space and other facilities is gratefully acknowledged. 
TABLE OF CONTENTS

Page

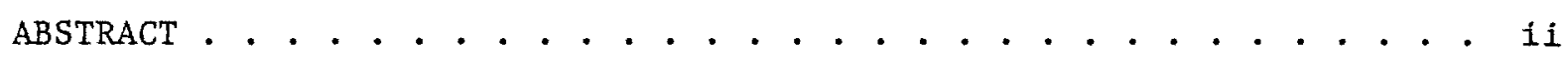

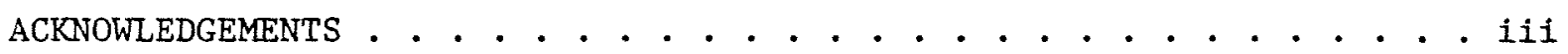

TABLE OF CONTENTS . . . . . . . . . . . . . . . . . . . . . . . . . . . . IV

LIST OF FIGURES • • • • • • • • • • • • • • • • • • • • • • • • • • • vi

Chapter

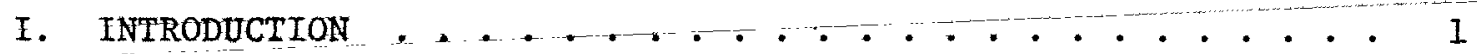

Organization of the Report . . . . . . . . . . . . . 5

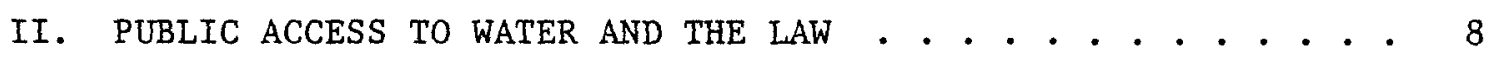

State Ownership of Surface Water . . . . . . . . . . . 8

Private Rights in Surface Water . . . . . . . . . . 12

Maintenance of Minimum Streamflow . . . . . . . . . . . 13

Recognition of Public Right of Access . . . . . . . . . . 15

Purposes for Which Public Waters Can be Used and Access

Obtained . . . . . . . . . . . . . . . . . . 16

Navigation and Boating . . . . . . . . . . . . 17

Fishing . . . . . . . . . . . . . . . . . . 18

Hunting . . . . . . . . . . . . . . . . . . . 20

Camping and Other Public Rights of Use . . . . . . 22

Navigability and Stream Bed Ownership . . . . . . . . . . 24

Stream Bed Ownership Under Civil Law . . . . . . . . 28

Stream Bed Ownership Under Common Law . . . . . . . . 34

Problems Associated with Statutory Navigable

Streams . . . . . . . . . . . . . . . 35

Water Rights Adjudication and Navigability . . . . . 40

Use of Banks and Shores . . . . . . . . . . . . . . . 42

Locating the Boundary Between Public and Private

Ownership . . . . . . . . . . . . . . . 45

Beaches and Tidal Waters . . . . . . . . . . . . 49

III. PUBLIC ACCESS TO WATER IN OTHER JURISDICTIONS • • • • • • • $\quad$ • 53

Public Access Trends in the Eastern States . . . . . . . 54

Public Access Trends in the Western States . . . . . . . 56 
Federal Legislation Affecting Water-Based Recreation . 59 National Wild and Secnic River System . . . . . 60

IV. GAINING ACCESS AND IMPEDIMENTS TO ACCESS . . . . . . . 65

Trespass on Private Property Prohibited . . . . . . . 65

Public Access Points ... . . . . . . . . . . 70

Public Parks ................... 70

Highway Rights-of-Way . . . . . . . . . . . . 74

Private Lands Open to the Public . . . . . . . . 76

Barriers to Public Access and Travel . . . . . . . 77

Fences ...................79

Dams and Diversion Works ............ 79

Posted Private Property . . . . . . . . . . . 83

V. SPATIAL ASPECTS OF PUBLIC ACCESS . . . . . . . . . . 85

Access to Streams . . . . . . . . . . . . 85

Easily Accessible Streams . . . . . . . . . 97

Moderately Accessible Streams . . . . . . . . . 97

Streams Difficult of Access ...... . . . . . 100

Access to Lakes . . . . . . . . . . . . . 102

VI. SUMMARY AND CONCLUSIONS . . . . . . . . . . . . 107

REFERENCES . . . . . . . . . . . . . . . . . . . . 118 
Figure

Page

1. Are These Streams Navigable??? . . . . . . . . . . . . 25

2. Ownership of Stream Beds: Civil Law and Common Law . . . . . . . 30

3. Survey Lines and Streams . . . . . . . . . . . . . . 36

4. Cross-Sectional view of Stream . . . . . . . . . . . . 48

5. Basic Legal Controls Affecting Public Access Rights . . . . 55

6. U. S. Wfld and Scenle River system . . . . . . . . . . 66 62

7. Access Sites in Public Parks . . . . . . . . . . . . . 71

8. Public Access from Highway Rfghts-of-Way . . . . . . . . . 75

9. Private Land Open to Public Access . . . . . . . . . . . . 78

10. Fences Obstructing Public Access . . . . . . . . . . . . . 80

11. Small Dams Obstructing Public Access . . . . . . . . . . . 82

12. Posted Private Property . . . . . . . . . . . . . . . 84

13. Big Cypress Creek . . . . . . . . . . . . . . . . . 87

14. Floatable Texas Waterways . . . . . . . . . . . . . . . 91

15. Streams Believed Open to Public Access . . . . . . . . . . . . 93

16. Recreational Streams . . . . . . . . . . . . . . . 95

17. Recreational Streams . . . . . . . . . . . . . 96

18. Easily Accessible Streams . . . . . . . . . . . . . 98

19. Moderately Accessible Streams . . . . . . . . . . . . 99

20. Almost Inaccessible Stream . . . . . . . . . . . . . . 101

21. Lake Buchanan: River Authority Reservoir . . . . . . . . . 105

22. Canyon Reservoir: Corps of Engineers Reservoir . . . . . . . . 106 
CHAPTER I

INTRODUCTION

Few areas of Texas water and property law are more poorly understood than those which relate to the issue of public access to the waters in Texas lakes and streams. There are a few general booklets and guides available-which discuss the features of the more interesting and accessible waterways in the state, but most are directed toward some very specific use such as canoeing. This report will be directed at any lawful recreational use. Most recent studies of the recreational use of Texas public water resources nowhere address themselves to the basic issues of access, the law controlling public access to water and the spatial limitations on points of access; or if they do, they merely give a short disclaimer that the problem is too complex for discussion. Neither have state agencies given the matter sufficient attention, and it is unrealistic for these agencies to undertake water resource and recreation planning studies without giving the most careful consideration to the institutional or legal constraints imposed by existing Texas water and property law. Surprising$1 y$, these critical issues have never been comprehensively studied in Texas by legal scholars, resource management disciplines such as geography, nor by any of the resource management agencies of the state. Nevertheless, limited access to public water resources is becoming an increasingly serious problem in this state as the rapidly burgeoning population seeks to avail itself of these recreation opportunities.

The recent significant surge in public demand for water-related recreational opportunities was recognized in the report of the National Water 
Commission. 1 There 1 was noted that:

Many socioeconomic and technological changes in American life have combined to intensify national demand for recreation. Increasing productivity, resulting in more leisure time and income, combined with a growing population, stimulate recreation demand. In addition, increasing urbanization, greater transportation capabilities, higher levels of educational attainment, timesaving and laborsaving household appliances, and an evolving lifestyle favoring outdoor recreation all add to the growing demand for recreation. [77, p. 274]

A recent study indicated that during 1968-1970, 43 percent of all outdoor recreation in Texas where rivers and streams total 80,000 miles in length, occurred on or beside the state's waterways. $[18, p, 1]$ Recreational use of Texas streams is expanding faster than in other states, having increased more than 9,000 percent in the ten-year period from 1965 to 1975, according to the Texas Parks and Wildlife Department, especially in such areas as the Texas H111 Country which are near large population centers. [115, p. 16C]

For example, this increased interest and activity is shown by the dramatic increase in canoeing on Texas streams in the past several years. Though river floating does not rank particularly high in relation to other outdoor activities when comparing total statewide participation, no other single outdoor activity has experienced such a prectpitous increase over a similar period of time. [115, p. 16C; also see 85] A recent survey by the Texas Parks and Wildlife Department showed that from 1969 to 1976 the demand for rental canoes rose approximately 6,000 percent on the more popular and accessible streams. The scenic Guadalupe River in the Hill Country accounted for about two-thirds of this total, but portions of the Brazos and San Marcos rivers and the Rio Grande also were popular. Less than a decade ago river floating was described as minimal, uncongested and easily managed, but on the Guadalupe River in Comal County alone, it is estimated that

IAn Annotated Bibliography on River Recreation [1] provides entry to a vast literature on this phenomenon. Problems and research opportunities in water-based recreation are discussed by Lime [61]. 
100,000 day-trips will be made this year, compared to fewer than 5,000 just eight years ago. [45, p. 8]

The impact of tourists attracted to the water recreation opportunities of Comal County is vividly described:

On a good weekend, when the river and summer temperatures are high more than 100,000 visitors Inundate Comal County (pop. 24,300), camping shoulder to shoulder along the Guadalupe, gunning huge motor homes over the narrow winding road that intertwines with the river, and parking vans and pickups on the sparse right-of-way and adjacent private property. [45, p. 7]

Though this description paints an undesirable ptcture, the economic benefits of the tourist influx are inescapable. The value of river recreation in Comal County amounts to more than $\$ 1$ million per year with an average daily expenditure of $\$ 6.48$ per person, spent in various sectors of the economy such as service stations, food stores, recreation, eating places, etc. It is estimated that nearly 700 jobs in the county are directly attributable to tourism. [45, pp. 7-8]

Although fisherman, boaters, swimers, campers and canoeists are all we11 aware of the potential for recreation on Texas lakes and streams, the demand for recreation of ten remains unsatisfied. This can be attributed primarily to limited access and the fact that waterways have not been developed for ready public use; to the fact that riparian landowners feel that their adjoining property will be jeopardized by large numbers of river users; and also, because there is considerable disagreement between landowners and recreationists over which waterways are public. $[18, \mathrm{p} .1]$ For all these reasons, the underlying legal and geographic issues which relate to public access need to be thoroughly investigated to help clarify the rights and duties of the public and private property owners, and to attempt to measure the degree to which the public is perhaps being denied its lawful right to access. 
This research report examines the problems of public access to surface water in Texas in the context of existing water and property law and in relation to the spatial characteristics of the resource. The more specific objectives of this project and research report are:

1) To review existing Texas land and water law relating to public access and to examine the institutional or legal constraints inherent in the law which have important effects on public use of the water, beds and banks of streams and lakes.

2) To suggest the most desirable modification or alternatives to the present legal system to help lessen the growing conflict between the recreation seeking public and landowners on streams and lakes.

3) To illustrate the problems the public faces in gaining access, and then the impediments to recreational use of public waters once access is obtained, using the example of representative Texas streams and lakes.

4) To investigate the development of a classification system which would help identify public waters as being navigable, either in fact or by statute, and which are thus subject to public use.

The methodology employed in this report involves the analysis of the impact of the legal and physical constraints on the opportunities for public access to, and use of, navigable streams and lakes. Both geographic and legal research techniques are utilized, then the findings developed by this dual-discipline research are further synthesized into this project completion report.

A11 too often, water-based recreation or water management studies undertaken by geographers and related disciplines fall to take proper account of the very important institutional or legal framework which controls the utilization of water resources, and which serves as an often invisible 
absolute constraint on its management. Alternatively, studies of the legal aspects of these problems usually fail to properly consider the physical and spatial milieu where the laws must operate, and thus such studies are sometimes difficult to apply in practice. The resulting compartmentalization of information by separate disciplines is perhaps partially responsible for the fragmentation of information relating to the rights and problems of public access to water. Because this phase of Texas land and water law is so poorIy defined and understood, and because the literature is so sparse on the subject, it is hoped that this dual-discipline research will serve to fill a significant void. Without doubt, the unsettled legal picture leads to many unnecessary conflicts between landowners along streams and lakes and members of the public. Additionally, water resource and recreation administrators and planning agencies are hampered in their management and planning efforts by these legal uncertainties.

Organization of the Report

In the material which follows this brief introductory chapter, Chapter II summarizes the evolution and development of the relatively sparse water and property law which relates to the problem of public access. It deals with state ownership of surface waters and the rights which private individuals may acquire in them, and examines the problem of maintaining minimum stream flows essential to water-based recreation. It discusses the recognized rights of public access to surface waters for a number of navigational and recreational purposes. It also examines the crucial question of navigability of lakes and streams, and the related question of stream bed ownership, including the unusual problems associated with their determination in Texas. It explores the even less-settled issue of public use of banks and shores and the difficulties of trying to establish a well-defined boundary 
between public and private ownership. Flnally, it contrasts the notable differences between rights of access to Gulf Coastal waters and inland waters. The author has attempted to discuss the law relating to public access in this and later chapters in layman's language so that it can be more readily understood by a wider circle of interested readers.

Chapter III provides a very general survey of the problems of public access to water in other jurisdictions, many in notable contrast with Texas, and examines some emerging trends in the eastern and western Untted States. Apparently there are less notable differences pertaining to recreational use of surface water between riparian and prior appropriation doctrine states than exist for consumptive water uses. It further examines relevant federal legislation which might have some effect on public access to and recreational use of water resources, especially the emerging National Wild and Scentc River system. Chapter IV continues the legal-geographic analysis of recognized access sites, such as from public parks or highway rights-of-way, and once public access is achieved, the various impediments which the public can reasonably expect to encounter on most streams and some lakes. Numerous examples of the kinds of access points and impediments are given for purposes of illustration.

Chapter $V$ discusses some of the spatial aspects of public access, primarily those which relate to the spacing of access points along streams. It also describes attempts to improve access to public waters in Texas, and surveys the sources of information on access available to the recreation-seeking public. Opportunities for public access to lakes relate mostly to the type of agency managing the reservoir, in contrast to streams which are normally not under such management. Again, examples, illustrated by maps, are given which show varying degrees of accessibility. Chapter VI sumarizes the 
preceding chapters, discusses the conflicting views over the public access issue along with suggested measures for alleviating the problem, and lists the conclusions of this study.

It must be admitted that this completion report is still by no means the definitive treatment of the problems of public access to water in Texas. Nevertheless, it is anticipated that it will provide a basic overview of the nature of these problems for the interested layman, either riparlan landowners or the recreation seeker, and it should be of considerable value to water resource and recreation planners and administrators, and also to attorneys who might have occasion to deal with the problems of public access. This report is not intended to serve as a forum for representing the views of any particular interest group, either landowners on public waters or the recreation-seeking public, on such a highly controversial subject. It is intended to be as objective as possible a summation of the rights and duties of these conflicting interest groups. Finally, it is hoped that this publication will be of some assistance in clarifying and resolving the problems of public access to water, and that it will serve to point the way for more specific studies of the problem by Texas land and water resource agencies, or for scholars with funded research. 
CHAPTER II

PUBLIC ACCESS TO WATER AND THE LAW ${ }^{1}$

\section{State Ownership of Surface Water}

State ownership of surface waters in Texas was first asserted in the appropriation statutes of the $1880^{\prime} \mathrm{s}$ and $1890^{\prime} \mathrm{s}$. Prior to this, however, the state had a long history of allegiance to the very different ripartan doctrine. Riparian water rights continued to be recognized after the initiation of the appropriation system, so that Texas is one of several dualdoctrine states, recognizing both doctrines. The riparian doctrine was first introduced Into Texas over 200 years ago during the Spanish settlement of San Antonio. Spanish legal principles and practices relating to water were continued essentially unchanged by the Mexican government after 1821, and later by the Republic of Texas until 1840. Because extensive tracts of Iand were granted by the Spanish and Mexican governments in Texas, any water rights associated with them must continue as an important element of Texas water law. Approximately 120 million of the 173 million acres of

${ }^{1}$ Among helpful guides to the literature on water law are Jacobstein's and Mersky's bibllographies $[48 ; 49 ; 50]$. The most comprehensive single source on Texas water law is Hutchins' The Texas Law of Water Rights [46], which is now somewhat dated. Other useful general materials are found in the section on "Waters" in Vol. 60, Texas Jurisprudence 2d, a legal encyclopedia, and in Laws and Programs Pertaining to Water and Related Land Resources [126]. Most statute law concerning water is codified in the relatively new Texas Water Code [125]. In addition to the judicial opinions in the cited cases, especially helpful materials on particular aspects of the problems discussed in this report are Biggs [5], Hawkins [42], Mcknight [64; 65], Roberts [87], Stiles [101], and Texas Jurisprudence 2d $[4 ; 136]$, as are two very succinct summaries [123; 138] of Texas law pertalning to public access. Much of the information for the first two sections of this chapter was derived from the author's unpublished Ph.D. dissertation [107], and thus is largely undocumented. 
present-day Texas were originally encompassed in Hispanic grants, the Mexican government alone granting about 100 million acres during the period between 1821 and 1836. Though many of the grants were not perfected, title to over 26 million acres, about one-seventh of the area of Texas, can be traced to them, much of this land located on the coastal plain and in the Rio Grande Valley [32, pp. 27-28]. It was once generally accepted by Texas courts, water agencies, and affected landowners, that lands granted by Spain and Mexico carried comprehensive riparian rights, fncluding the 1mplied right to use streams for irrigation. Not until 1962 was it decided in Valmont Plantations $v$. Texas [132], that rights to water for irrigation and other major consumptive uses did not accrue from these grants unless expressly mentioned. The few specific grants of irrigation rights were made in the vicinity of San Antonio and E1 Paso. Though riparians on hispanic grants have some rights, among them the right to use streams for navigation and fishing, their rights are much more restricted than those of later riparians. Lands granted by the Republic of Texas between 1836 and 1840 are also controlled by Hispanic law and carry the same limited riparian water rights as prior grants.

More extensive riparian rights attach to all lands granted by the Republic of Texas and the state between 1840 and the Appropriation Acts of 1889 and 1895, a period of time when vast acreages of Texas land passed from the government into private hands. In 1840, the Republic of Texas adopted the common law of England as the rule of law, thus acquiring the English riparian doctrine. The courts, in a series of decisions adjusting to environmental realities, modified the original doctrine giving riparian landowners the rights to make reasonable use of streams for irrigation and other extensive and consumptive uses. It was popularly assumed in Texas during 
the nineteenth century that riparians could use as much water as they needed for almost any purpose.

As early as 1872 the Texas Supreme Court pointed out the unsuitability of the riparian doctrine for the arid and semi-arid portions of the state, and suggested legislation to institute the appropriation doctrine, which was rapidly surplanting the riparian doctrine in other Western states. Even earlier, a number of special laws gave canal companies and individuals the right to use specific quantities of surface water for a limited number of years. However, it was not until near the turn of the century that the state formally adopted the prior appropriation system. One reason for the riparian system's persistence was that Texas, upon annexation as a state in 1845, retained its public lands and thus was not influenced by federal law and the federal landownership system which was so important in shaping the early development of the appropriation doctrine in California and elsewhere in the west. Following the appropriation act of 1895 , land acquired from the state has no longer carried riparian water rights. Instead, individuals must obtain water rights from the state through established statutory procedures. The superior position of pre-existing riparian water rights has uniformly been recognized by all appropriation statutes.

Both appropriation statutes declared unappropriated waters to be public property. The 1895 act separated storm and flood waters from the ordinary flow and underflow, and treated the former as appropriative to which riparian rights did not attach. It authorized diversion of the ordinary flow and underflow only to the extent that riparian rights were not affected.

Under the 1889 act the purposes for which appropriations could be made were irrigation, domestic, and other beneficial uses. The 1895 act listed irrigation, mining, milling, and the construction of waterworks for cities or towns, and stockraising as authorized purposes. 
Between 1895 and 1913 a landowner could appropriate water merely by filing a sworn statement and map with his county clerk describing his water diversion. It is not surprising that under this loosely-administered system water rights claims often overlapped, described unrealistically large irrigated acreages, or claimed more water than the stream could possibly produce. They are called "certified filings" because after 1913 the state recognized and recorded certified copies of these early diversions, resulting in almost 1,000 fillngs.

In 1904, the Texas Constitution was amended (Tex. Const., Art. XVI, Sec. 59a), stating:

It is the right and duty of the state to develop and conserve its water resources for the purpose of irrigation, navigation and the development of hydroelectric power.

Pursuant to this mandate, the legislature in 1913 established a new permit procedure for acquiring appropriative rights. Applications for permits were placed under the jurisdiction of the newly formed Board of Water Engineers. Public or appropriable water, title to which had not already passed from the state, was declared to be the property of the state. Public waters were defined as:

The unappropriated waters of the ordinary flow and underflow and tides of every flowing river or natural stream, of all lakes, bays or arms of the Gulf of Mexico, collections of still water and of the storm flow or rain waters of every river or natural stream, canyon, ravine, depression or watershed, within the State of Texas, the title to which has not already passed from the State, are hereby declared to be the property of the State, and the right to use thereof may be acquired by appropriation in the manner and for the uses and purposes hereinafter provided.

This provision is now codifled as Section 5.021a of the Texas Water Code [125], and these waters are "Held in trust for the benefit of the people," thus establishing a general right of public use. In State v. Bradford [98] the Texas Supreme Court declared that this reservation of waters to public 
use implies all rights necessary for their full use and enjoyment, and that the reservation must be 1iberally construed [5, pp. 576-77] .

\section{Private Rights in Surface Water}

The principal private rights in water are riparian rights, which arise out of the ownership of land abutting on water, and rights acquired by virtue of the appropriation acts. [136, p. 341] As noted in the previous section, private appropriative rights may be acquired to use public waters. Both earlier riparian rights and later approprtative rights are only a right of use. The purposes for which appropriations can be made are specified by statute (Texas Water Code, Sec. 5.023) [125] and include:

a. 1) Domestic and municipal uses

2) Industrial uses

3) Irrigation

4) Mining and recovery of minerals

5) Hydroelectric

6) Navigation

7) Recreation and pleasure

8) Stack raising

9) Public parks

10) Game preserves; and

b. Any other beneficial use

In 1931, the act was amended to establish priorities of water use between two applicants from the same source (Texas Water Code, Sec. 5.024) [125]. The purposes for which appropriations can now be made are, in order of priority:

1) Domestic and municipal uses

2) Water to be used in processes designed to convert materials of lower order value into forms having greater usability and comercial value 
3) Irrigation

4) Mining and recovery of minerals

5) Hydroelectric power

6) Navigation

7) Recreation and pleasure

8) Other beneficial uses

It should be noted that these priorities concern only pending applications for appropriation and do not upset the normal time prioxity or disturb outstanding permits for lower priortty uses.

Though under the provisions of Sect. 5.023 of the Texas Water Code [125] listed above, public water may be appropriated, stored, or diverted for navigation, recreation and public parks, it is obvious that the acquisition of private rights in water for recreation has a rather low priority in the hierarchy of Texas water rights, and until recent years very few water rights have been acquired for these purposes. It has been observed that the treatment of recreation in states which have a statutory system of water use preferences may vary with the relative economic importance of the tourist industry to the state; thus, recreational use has a higher status in Florida than in Texas. [72, pp. 755-56] Nowhere in the Water Code is there any direct recognition of public rights in regard to the recreational use of public waters. Biggs points out that ". . this onfssion is noteworthy and indicates that the public has no single statutory source from which to determine their rights." [5, p. 581]

Maintenance of Minimum Streamflow

The need for maintaining minimum streamflow for recreation and for protection of fish and wildlife resources has only recently come to the attention of recreation planners and managers and wildlife management agencies. 
Methods have been devised for calculating stream flow requirements for waterdependent activities such as swimming and boating. [91] Those persons concerned with river management and planning must contend with water already appropriated as a part of the existing water rights situation. of even more concern are future appropriations and unquantifled or excessive appropriations. It is noted that the effects on over-appropriated streams may be mitigated if state or federal law provides minfmum flow requirements, or provides that the creation of the system under which the eiver-mager operates constitutes a reservation of the necessary water. [93] In Texas, though these issues have been discussed in the legal literature, only recently have they become of major concern to state water agencies. [51; 69, pp. 25-28]

The Texas Parks and Wildlife Department, concerned with protecting the state's fish and wildife, has recently declded that stream flow during droughts and inflow into coastal bays and estuaries is being threatened by upstream water rights applications. In January, 1977, the Department, represented by the Attorney General, filed a claim for water rights for fish and wildlffe as a part of the adjudication of water rights in the Medina River sub-basin of the San Antonio River basin. The claim was based on several alternative theories:

The claim of rights asserted herein is premised upon the doctrines that the state's fish and wildlife resources are slgnificant and important natural resources, and that the fiduciary duty of the Texas Water Rights Commission to conserve and manage the beneficial utilization of the state's water resources requires sald Comission to recognize its role as co-trustee with the Texas Parks and Wildlife Department to protect and conserve the state's fish and wildlife resources in the Commission's allocation of water rights and recognition of claims thereto.

Alternatively, the Department claims that flow sufficient to satisfy the requirements of flsh and wildiffe is implicitly reserved within the 'normal flow' as defined by Motl v. Boyd, and such flow is not available for appropriation as it exceeds the requirements of fish and wildlife.

The Department, further and alternatively, claims that the state has riparian rights of assured flows of fresh waters within its watercourses 
which are resonably adequate to support the state's fish and wildlife resources and maintain stable ecosystems. [73, p. 3]

Though denied, it was reported that these efforts were discouraged by pressure from lawmakers. [128d, p. 3] Later, the Department eventually decided not to actively enter adjudication proceedings seeking water rights to maintain adequate flows in state streams. [128e, p. 2] There was already some question about claims in river basins where adjudication had been completed. It was contended, however, that the state was attempting to maintain water for a historic use, and thus it was not necessary to file a claim; and on the Rio Grande, it was believed that the federal government could step in and require action because it is subject to international and interstate agreements. [128d, pp. 3-4]

Recognition of Public Right of Access

Though most streams and lakes are in fact used for the navigational and recreational needs of the public, it must be recognized at the outset that there is no express statutory authority granting the general public the right of access to the inland surface waters of Texas. [Supra, p. 13] Nevertheless, despite the absence of statutory authorfty, there is a substantial number of court cases dealing with various aspects of questions pertaining to the public's right of unimpeded travel on state-owned waters, and the right to make use of the banks and shores of streams and lakes.

However, the status of the law of public access developed in these court opinions is not at all clear and is sometimes confusing and difficult to understand, especially for the lay public, for a number of reasons:

1) First, each case involves a unique set of circumstances which are usually peculiar to the tracts of land where public rights of access are in dispute. Thus, the outcome of any case probably will not find ready application to other disputes and other situations. In this regard it is impor- 
tant to know when grants of land passed from the sovereign into private hands, the nature of the surface water in dispute, and the nature of the attempted public use.

2) A great deal of the law relied on to establish public access rights does not involve a direct holding by the courts. Much of it is "dicta," which is merely an expression of the court's views on matters which are not really central to the issues resolved in the opinion, and are of less legal persuasiveness. Also, even less weighty statements of law such as attorney general's opinions must sometimes be relied on.

3) Finally, much of the law pertaining to public access developed in the late 19 th and early 20 th centuries. Since then the courts have generally become less protective of private rights and economic interests, and more supportive of public rights. Because there are few post-World War II cases on access issues, and none which involves the central issue of public access rights to Texas lakes and streams, it is difficult to predict the course of future decisions in protecting and/or expanding public rights, especially as they relate to water-based recreation. [123, p. 41; 138, p. 9]

For all these reasons, it is particularly difficult to establish concrete rules and to define general principles of law with which the general public, riparian property owners and resource management agencies are familiar and which can be applied to the solution of problems in practical situations.

Purposes for Which Public Waters Can be Used and Access Obtained

Individual members of the general public have more or less well-defined rights to use publicly-owned waters for a number of purposes. The most widely-recognized purpose is for navigation--and related recreational activities such as boating, canoeing, rafting and floating. Other often-recognized purposes of public access, not connected with navigation and all having 
a recreation connotation, are for fishing, hunting, bathing, picnicking and camping on the waters, and banks and shores below the line where private ownership begins. [102, p. 198]

Most uses other than for navigation are fairly recent additions to the 1aw. Stone notes that until recently, the public made little demand for the use of inland waters, other than for navigation and to a lesser extent for fishing. During development of the common law in England, the general public had netther the leisure time now the money to attempt any other substantial uses of inland waters. Also, at the time when the United States was developing its laws concerning inland waters, a broad public demand for their use was still not evident, and until the modern era, there has been Ifttle occasion for the law to consider public uses other than navigation. $[102$, p. 203]

With reference to use of Texas' public waters, Texas Jurisprudence 2d emphatically states, "Navigable waterways... are the property of the state, and all members of the public have certain rights therein, such as the right of navigation, fishery, and the right to hunt and camp along the shore below the line at which private ownership begins," [136, pp. 339-407] citing a 1917 Court of Civil Appeals opinion, Dincans v. Keeran [27], which is normally classed as dicta.

Navigation and Boating. With respect to inland navigable waters such as lakes and streams, the basic public right of navigation is generally recognized in this country. This may include the right to pass over and use the land for anchoring, poling a vessel, and other purposes incidental to navigation. [102, p. 198]

In Texas, the lawful right of the public to travel along the navigable waters of the state is settled beyond dispute. [123, pp. 41-42; 138, p. 9] 
As early as 1863 the Texas Supreme Court, in Selman v. Wolfe [92], held that the navigable streams exclusively within the state are to be considered as public highways, and made this policy statement:

It is the settled policy and cherished object of this state to guard its navigable streams from obstruction and to secure and improve them as common highways of trade and travel for such of its citizens as might wish to use them for this purpose. [92, p. 71]

The fact that the commercial purposes mentioned in Selman $v$. Wolfe, trade and travel, are sometimes accorded a higher status than most recreational uses by courts in other jurfsdictions has caused some authortities to question the ruling's applicability to public recreational pursuits in Texas. However, other authorities believe it can be inferred from existing case law that Texas courts would probably be receptive to the argument that recreational use itself is evidence of navigability and of equal importance to commercial use. [123, pp. 41-42; 138, p. 9] As will be shown in subsequent sections, a much more difficult problem is the determination of navigability of the lake or stream in question.

Fishing. There are a number of statutory provisions and significant cases which deal with the right to fish in public waters going far beyond the data of Dincans v. Keeran [27]. Regarding the ownership of fish in public waters, a statute (Tex Civ Stat, Ann., Art. 4026) provides that al1 fish and other aquatic animal life contained in the fresh water rivers, creeks, and streams, and in lakes and sloughs subject to overflow from rivers or other streams, are the property of the state. [46, p. 95] It was further established in Stephensen $v$. Wood [100], that no person has any vested property right in fish in the public streams and coastal waters of Texas. [46, p. 95]

Under the English common law, the owners of land along navigable streams above tidewater had the exclusive right to fish there. However, 
this rule is not applicable in Texas in determining the right to fish in navigable streams, and has been specifically rejected. [136, p. 495; 123, p. 42; 138, p. 9] In Diversion Lake Club v. Heath [31], an important case where the Texas Supreme Court passed on several issues relating to the right to fish in navigable waters, it was held that:

The general rule is well established by the authorities that the right to fish in a stream, whether belonging to the public in common or exclusively to the owners of the land bordering the stream, is determined by the ownership of the bed. [31, p. 443]

The thusual question resolved in this case was stated as follows:

Do the public have the right to fish in a lake created by the lawful construction of a dam across a river not navigable in fact, but declared navigable by statute, or does the exclustve right to fish in such a lake belong to one who owns both the bed of the lake, except that part of same which was originally the bed of the river, and the land bordering the lake on both sides? [31, p. 442]

In this case the court held that the public who gained lawful access to the lake had the right to fish in its waters not only above what was the bed of the navigable river, but also above parts of the lakebed that were privately-owned. The water in the lake, regardless of the ownership of the bed, was still public water, and the permit to appropriate water gave no title to the water nor to the fish in it, and gave no exclusive right to take fish from the lake. It was determined that the owner had no right to interfere with the public in using the river for navigation, fishing, and other lawful purposes, other than necessary interference in constructing and maintaining the dam and diversion works in a reasonable manner. [46, p. 97; a1so see 66]

Thus, for fishing purposes the public may use the beds of navigable streams and their banks up to the line which divides public ownership from that of the adjoining riparian landowner. [46, p. 97] Nevertheless, it is also well settled that the public has no right to go beyond this dividing 
Iine onto private property without the consent of the landowner. As previously noted, since all fish in fresh water streams, lakes and sloughs subject to overflow are public property, the state has the right to regulate such waters and their beds and the taking of fish therefrom. However, that this does not expand the public right of access was determined in Taylor Fishing Club v. Hanmett [106], where the Court of Civil Appeals stated:

The . . rule.. . Is merely for the purpose of protecting the fish in order to prevent a depletion of the supply thereof. It was never intended that thereby a stranger should have right to enter upon the private property of another for the purpose of catching fish, although the fish until caught belong to the public. [106, p. 130]

And, in the aforementioned Diversion Lake Club $v$. Heath, it was the court's opinion that the public had no right to use the banks of the lake which lay beyond the original banks of the river and were thus the property of the riparian landowner. So far as the surrounding privately-owned land was concerned, the question is controlled by the statute (Tex Penal Code, Art. 1377) which prohibits entry upon the enclosed land of another, without his consent, for the purpose of fishing in a lake or stream. [46, p. 97]

In addition to the general principles discussed above, which recognize the right of the public to fish in Texas lakes and streams, the specific regulation of particular fishing activities is controlled by the Texas Parks and Wildlife Department under authority of the Uniform Wildlife Regulatory Act (Chap. 61, Texas Parks and Wildlife Code), and the numerous special laws pertaining to specific counties and local areas. [116]

Hunting. There is the dicta in Dincans v. Keeran [27], where the court specifically mentioned hunting as one of the reasonable uses of the navigable waters and shore lines of the state, below the line at which private ownership begins. [123, p. 41] However, the use of inland waters for hunting must be considered to be of minor consequence compared to boating 
and fishing. The very nature of hunting makes it very difficult to shoot and recover land game animals within the spatial confines of the publiclyowned bed and banks of streams, and the problem of trying to locate the dividing line between public and private ownership, as will be pointed out later, magnifies the problem still further. Probably the major exercise of the right pertains to the taking of waterfowl on publicly-owned lakes and streams.

Hunting is usually a much more rigorously regulated activity than those previously mentioned. Hunting in Texas is controlled by the Texas Parks and Wildlife Department under the terms of the Uniform Wildlife Regulatory Act (Chap. 61, Texas Parks and Wildlife Code). [116] This act applies to all of Texas' 254 counties, but there are also numerous other special laws and regulations which apply to particular regions, locales or counties. Under the act, the Parks and Wildlife Department is given authority to issue proclamations for application to certain parts of the state, though there is a procedure whereby these proclamations can be disapproved by the Commissioner's Courts of affected counties (Sec. 61.202, Texas Parks and Wildlife Code). [116]

Recently, an interesting case arose concerning the attempted regulation of hunting in publicly-owned river beds in three South Texas counties. Tri County Citizens Rights Organization $v$. Johnson [131], was a suit to prevent the Department from enforcing provisions of a proclamation, issued under the Uniform Wildlife Regulatory Act and published in September, 1971, declaring no open hunting season on game animals and birds, as follows:

There is no open season on game animals, game birds, or fur-bearing animals on State game preserves, statutory wildlife sanctuaries, United States wildife sanctuaries, within the corporate limits of any city, on public roads and highways or rights-of-way of such public roads and highways, and in State-owned river beds in Uvalde, Dimmit and Zavala Counties including, but not limited to, the Nueces and Frio Rivers. - . [Emphasis added; 131, p. 228] 
The proclamation was upheld in the above case, and continues in effect despite the fact that it was reported just last year that the Commissioner's Court in Zavala County had gone on record in opposition to the hunting ban. It should be readily apparent from the above discussion that the complexity of laws and proclamations regulating hunting over the state and the varied ways in which these regulations are applied from time to time and place to place make general statements of the law regarding hunting very difficult and subject to numerous exceptions. Suffice it-to-say, members of the public should check very carefully with Parks and Wildlife officials for information on all local regulations before trying to pursue any hunting activity on the streams and lakes of Texas.

Camping and Other Public Rights of Use. Camping is another of the reasonable uses of Texas' public streams and shorelines referred to in the dicta of Dincans v. Keeran [27], the case which probably spe11s out permitted public uses in the broadest terms of any reported case in Texas. However, this is a particularly difficult public right to discuss in detail. One might easily surmise from reading John Graves' Goodbye to a River, his classic story of a canoe journey down the Brazos River, that camping on any sand or gravel bar or river island is permissible:

- . I pulled onto a sand bar below a narrow flat that lay between the river and a mountain. . . I set up the little tent under a twisted mesquite, threw my bed roll into it, chopped dead limbs into firewood, and finally carried up the other things from the boat. [39, p. 15]

In the summer or a drouthy fall, when the river is low and you know it is going to stay that way, you can camp on low bars almost beside the boat and can reduce lifting and staggering and sliding to a minimum, but not with the big water running and two-foot rises and falls commonplace. [39, p. 42]

In actuality, however, the public right to use sand or gravel bars and islands encountered in rivers for camping and day use is a much more complex 
question. The law recognizes several different kinds of land area in streams and lakes, and whether or not these land areas are public or private property is related to the question of streambed ownership, which will be discussed later. In City of Victoria v. Schott [16], it was determined that islands arising from the state-owned bed of a navigable stream were the property of the state. However, the case falled to indicate whether riparian grants in the vicinity were subject to Hispanic civil law or the common law, and the result might dfferent the land grants were Hispanie as will be noted in a later section. [64, p. 379; 87, p. 308] Thus, it is virtually impossible to give a simple rule that has universal application to all situations which might be encountered on Texas streams.

Because of steep stream gradients in some of the more scenic and popular streams for canoeing and floating, such as the Upper Guadalupe River, finding suitable camping areas can present a problem because there are few sand and gravel bars which lend themselves to camping and day use. [117, p. 119] In addition, as alluded to by Graves, there is the ever-present danger of the water rising rapidly and unexpectedly from flooding or from water released downstream below major reservoirs. The natural, commonsense cautionary factors, in addition to the numerous legal uncertainties, make the use of bars and islands in rivers for camping and other prolonged uses a rather risky venture.

Within the scope of public rights sometimes recognized in other jurisdictions are such activities as plcnicking and bathing. [102, p. 198] Though these uses have not been specifically recognized or mentioned in the reported Texas cases, nevertheless, it would seem that they are implicit in some of the broader activities already discussed, particularly boating, fishing, and camping. Thus, in all likelihood, these uses are also permis- 
sible on Texas streams and lakes, and on the sand or gravel bars and islands In them.

Navigability and Stream Bed Ownership

As previously stated, the right of public access to the navigable waters of Texas turns on the critical question of stream bed ownership. The rather nebulous legalities of this situation have been broadly summarized as follows:

Although the public's ownership of the water itself is never questioned, use of and access to that water may depend on whether the land under or around that water is publie or private. If it is public (generally speaking, the larger, navigable bodies of water), the public can use it. If It is private, the weight of legal authority holds that the public cannot fish or boat there. . . [Also,] it is difficult to ascertain where a public stream bed ends and a private bank or shore begins. There is no easy formula for determining the width of a publicly-owned river bed. . . . Since most lands adjacent to Texas rivers are privately owned, the river recreationist must be very cautious not to infringe upon the rights of those landowners. [88, p. 19]

Figure 1 illustrates views of two Texas streams, one a narrow flowing river which might or might not be deemed navigable, and thus, subject to public use; the other, a broad, almost dry stream bed which might well meet the test of navigability. As these pictures illustrate, there is no way for the public to easily ascertain whether or not a particular stream meets the test of navigability and is open to public use.

In historical perspective early Roman water law, the source of the common and civil law, has been subjected to different constructions:

1) Under one view, the public interest attaches only to water in streams and the right to use it. This construction was adopted in England; and thus, under the comon law the sovereign retained title to stream beds only within tidewater limits.

2) Hispanic civil law jurisdictions adopted the opposing view that ownership of river beds was reserved to the sovereign, resulting in the beds of streams being publicly-owned. [87, pp. 299-300] 
Figure 1. ARE THESE STREAMS NAVIGABLE???

(2)

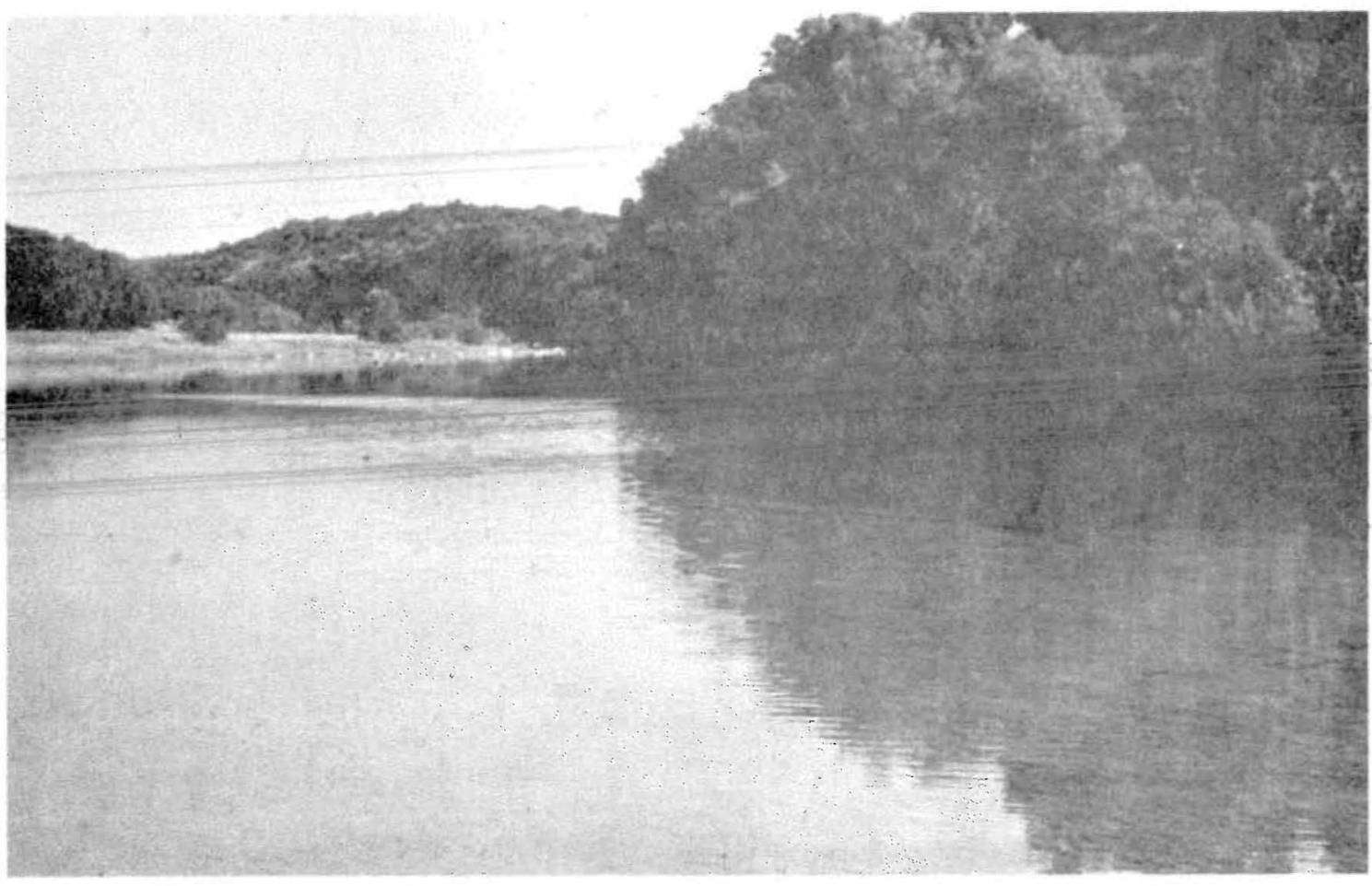

2

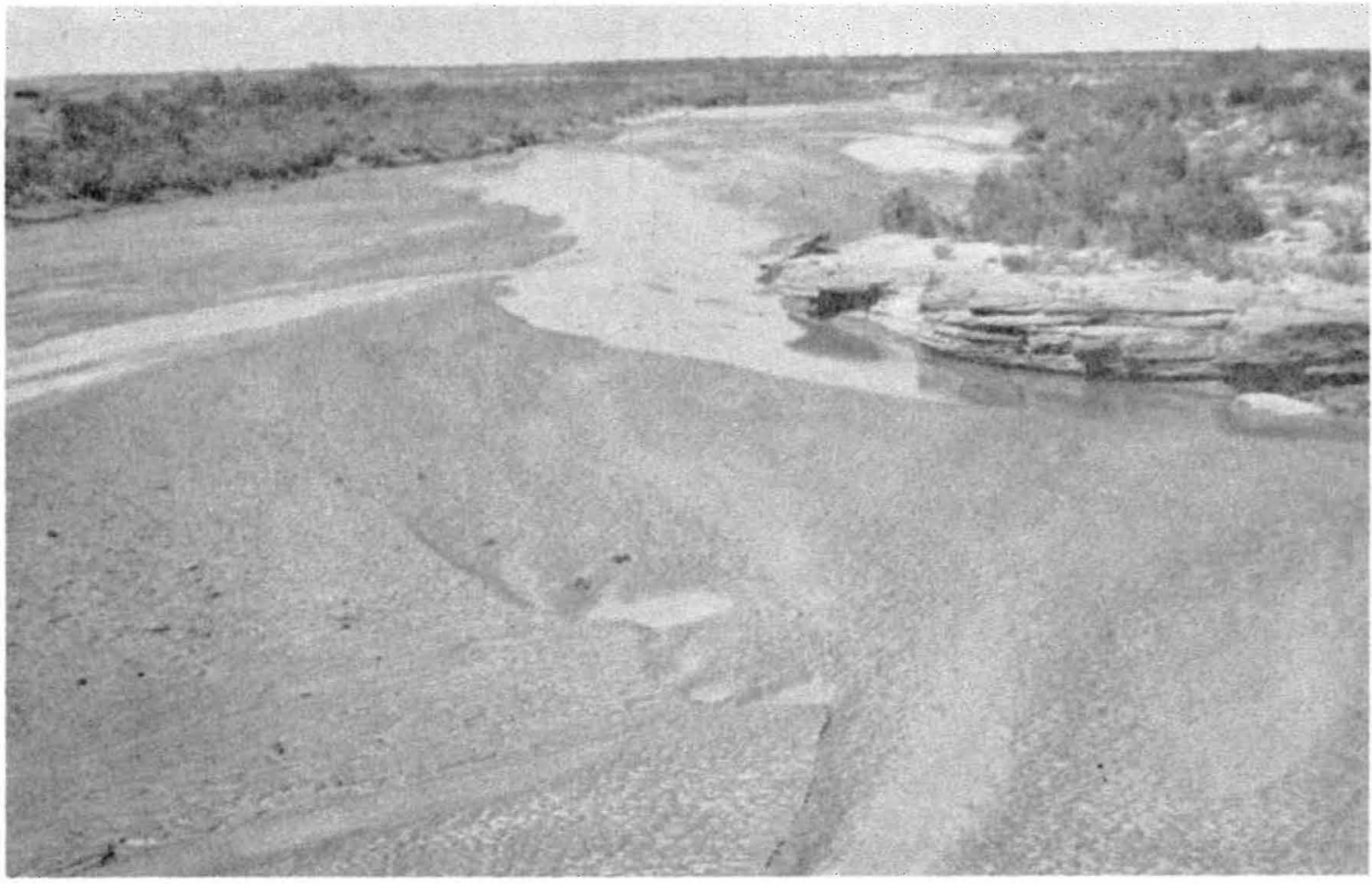


The English tidewater test of navigability was rejected in the United States. Instead a test of navigability in fact was adopted, so that all coastal and inland waters are subject to public use if they are capable of supporting navigation. Federal court decisions establish the legal test of navigability for state ownership; then each state may declare its own legal test of navigability for the purpose of establishing the public trust and rights of public use of waters. [77, p. 274]

Most states have adopted tests for navigabtltey for inland waters akin to the federal test, but Stone discusses a number of variations developed by the states to expand the relatively narrow federal definition of commercial navigability. [102, pp. 210-1], 216, 271] Case law on the subject of public access has not developed rapidly in this country for reasons explained in the report of the National Water Commission:

Many of the legal questions relating to navigability and the public trust are extremely complicated and must be resolved by the judiciary. It is this very complexity and uncertainty which have caused the states to be hesitant about moving forward to resolve questions of public access and use of many waters which have a high value for that purpose. [77, p. 275]

Texas is among a decided minority of jurisdictions which have adopted independent statutory standards for navigability. [5, pp. 577-78]

In Texas, there are also important differences in stream bed ownership, which ultimately depend on when the land was granted to private individuals by the sovereign. Because about one-seventh of the total area of the state of Texas came originally from Hispanic land grants and grants by the Republic of Texas before 1840, the ownership question is particularly important in Texas. Only about two percent of the state's land remains in public ownership. Nevertheless, of the total publicly-owned land remaining, approximately one-fifth is comprised of river bed acreage, and most of the legally navigable watercourses of the state are public property. [117, p. 8] 
Hawking has observed that the source of title to river beds in Texas is unlike that of the original thirteen states of the Union and the remaining states. Texas, upon its admission to the Union, reserved the title to the soll of the beds of streams as well as the public domain, and its sovereignty and boundaries have been recognized and settled by a series of subsequent treaties, agreements and litigation. [42] He argued that the trust doctrine alone would generally prevent passage of title to river beds into private ownership. In addition, in most instances each of the successive sovereigns disposing of public lands in Texas provided by general statute for the reservation of title to river beds. Thus, due to the combined effects of the trust doctrine and statutory reservations, the title to most river beds in Texas remains in the state. Only express language to the contrary can suffice to evidence the intent to grant exclusive private privileges and rights to land held for the common use and benefit of the public. [42, Pp. 493-96] Hawkins also noted the problems arising from the fact that boundaries of Texas river beds have not been more accurately determined and defined:

It is unfortunate that the issue has not long ago been settled in view of the fact that practically all riparian lands are now held in private ownership. A court decision at this late date determining what soil is river bed affects many hundred miles of boundary between publicly and privately owned land. . . . Ten of the thirteen principal rivers of Texas have an aggregate length of 4153 miles, or 8306 miles of such boundary. $[42, \mathrm{p} .500]$

However, it is difficult to establish a stationary and unchanging dividing line between public and private land, because rivers and their boundaries are constantly changing; thus, the law must provide rules pertaining to the effect of such changes on land titles. Roberts lists several categories of natural or man-induced changes:

- . 1) accretion, a build up or extension of riparian lands resulting from deposits of alluvium; 2) reliction, an extension of riparian lands resulting from a recession of the water; 3) erosion, the washing away 
of riparian land (eroston is often accompanied by reliction since the flow of water tends to move into the space previously occupied by the eroded bank, thereby leaving bare some land on the opposite bank); and 4) avulsion, a sudden break through of the stream into a new channel of ten across the neck of a horse shoe bend. [Numbers added for clarity; 87, p. 3181

Where these processes result in alteration of the boundaries between public and private land, problems arise. Early Texas cases developed appropriate rules of law to govern such changes without distinguishing between Spanish and Mexican grants and later grants by the Republic and state after the comon law adopted in 1840 . [87, p. 318] Thus, the boundaries of riparIan grants and the state-owned stream bed do not remain fixed but follow the changing boundaries of the river as accretion, reliction, erosion and avulsion occur.

Stream Bed Ownership Under Civil Law. The law in effect at the time a land grant was made is applicable in determining the ownership of beds, banks, and shores of navigable waters included in the grant. Thus, the laws of Spain and Mexico in effect when Hispanic grants were made and later by the Republic of Texas, until the common law was adopted as the rule of decision in Texas in 1840 , determine the rights of landholders under such titles. [4, p. 577]

Under Spanish and Mexican law, the sovereign was the owner of the beds of all perennial streams in what is now Texas, whether navigable or not. Although the sovereign could grant the beds of perennial streams to individuals, and apparently did in a few instances, it is not presumed to have done so, unless there is clear and unmistakable evidence that this was its intention. Therefore, for grants made by the Republic while Spanish and Mexican law was the controlling law in Texas, as well as grants made by the Spanish and Mexican governments, it seems that the riparian landowner's title extends only to the edge of the water of a perennial stream, the state 
retaining title to the bed. [4, pp. 583-84] (See Figure 2).

Thus, prior to 1837, private ownership of the beds of streams contained in or adjacent to Spanish and Mexican grants depended not on navigability, but upon whether the stream was classed as "perennial" or "torrential." A perennial stream is generally considered to be one which flows all or most of the year except in times of drought, and the beds of perennial streams are awned by the state. A torrential stream such as a gully or other channel which usually does not carry water and which flows only for short per1ods after heavy rainfall was considered to be privately-owned, as established in McCurdy v. Morgan [63]. [87, p. 300; 102, pp. 259, 262, 272; 123, p. 41; 138, p. 9]

McKnight has painstakingly reviewed the evolution of Texas court dectsions interpreting the Partidas, a compilation of Spanish and Mexican land and water law. [64; 65] In 1927 the very important case of State v. Grubstake Investment Assn. [99] reached the Texas Supreme Court. At issue was the ownership of the bed of the Frio River, a perennial stream, pursuant to an 1835 grant by the Mexican state of Coahuila and Texas. The state claimed title to the river bed as successor to the former sovereign; the riparian landowners claimed ownershtp of the bed to the middle of the stream, the common law rule. [64, p. 376]

The controversy centered around the construction of two provisions of the Mexican law; one providing that the river is the public domain and establishing rules for change of ownership if the river changes course; the other providing that if islands arise in the river, they belong to the riparian landowners in proportion to their adjacent estates. The logical inconsistency of the laws was under attack, and it was argued that if islands arising from the river bed vest in the riparians, should not the river bed 
Figure 2. OWNERSHIP OF STREAM BEDS: CIVIL LAW AND COMMON LAW
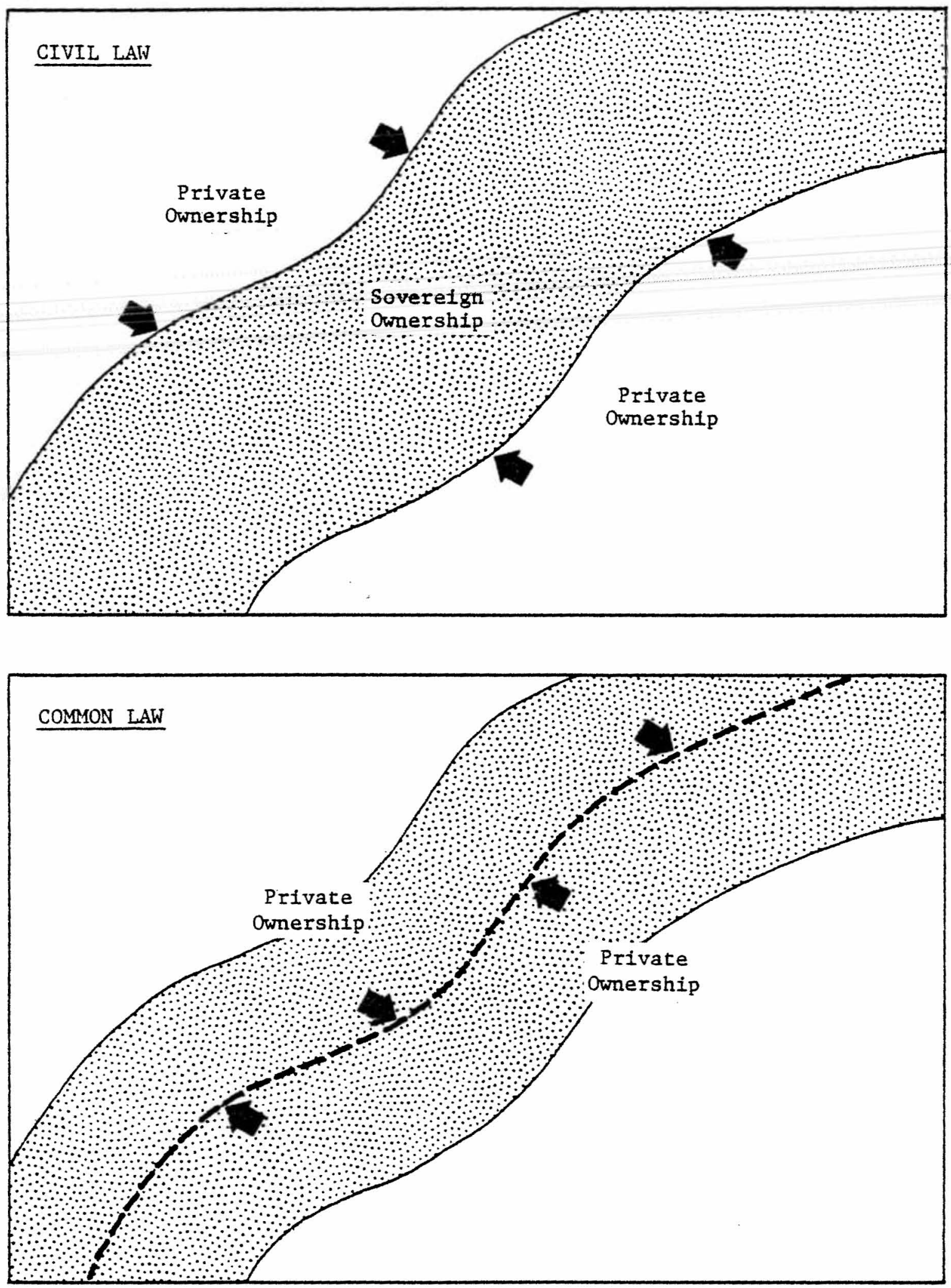
itself be considered their property as well? [64, p. 376] In deciding the case in favor of the state, the Court made a subtle distinction:

- . it should not be presumed that the text was formulated when it answered no need. . . . If the riparian proprietors actually owned the river beds, the islands or portions thereof within such beds would necessarily belong to such proprietors. Construing Law 27 as designed to operate by means of future grants effective when the islands appear, it both harmonizes with our interpretation of the other laws and accomplishes a just result. [99, p. 204]

The result of this case and the court's interpretation of the Partidas has been subjected to considerable criticism. [See-41]

To this point, all Texas cases examining ownership of stream beds under Hispanic law have involved situations where the stream in question was perennial or where torrential streams were included within the bounds of a grant, with no case involving a grant bordering a torrential stream. [87, p. 303] Roberts has summarized the rules developed by the cases relating to Spanish, Mexican and Republic of Texas land grants prior to 1837 as follows:

1) If the bed of a stream is within the grant and the stream is perennial, title to the stream bed was retained by the sovereign.

2) If the stream bed is within the grant and the stream is not perennial, title to the stream bed passed with the grant.

3) If the Mexican or Spanish grant borders on the stream bed and the stream is perennial, title to the stream bed was retained by the sovereign.

4) If the grant runs to the margin of the stream and the stream is non-perennial or "torrential," the riparian owner will take to the middle of the stream. However, - there is no direct authority on this point. $[87$, p. 304]

After the Republic of Texas gained its independence in 1836, Hispanic civil law continued to be applied until the adoption of the common law in 1840. [4, p. 577] In 1837, the Congress of the Republic, in an attempt to adapt and extend the prevailing Hispanic law, modified the civil law relating to the ownership of stream beds by passing an act relating to surveys of land lying along navigable watercourses. This statute, now codified as Art. 5302, Tex Civ Stat Ann, stipulated that land grant surveys 
should not cross navigable streams. Navigable streams were defined by the law as those which averaged thirty feet or more in width from the mouth upstream, and it declared that the beds of such streams were the property of the state. Thus, post-1837 land grants by the Republic and State do not convey the title to the beds of streams meeting the statutory definition to riparian grantees. [4, p. 584; 64, p. 377;87, p. 301; 102, p. 262; 123, p. 41; 138, p. 9]

However, if the stream is less than thirty feet in width, the bed does pass with the grant into private ownership. [4, p. 584; 102, p. 259] Biggs observes that the private ownership of nonnavigable stream beds creates an anomalous situation which precludes public use of waters which are publiclyowned. Because such waterways are not within the state's jurisdiction, members of the public have no right to use them. [5, pp. 579-80]

The new law went even farther than the previous civil law, in effect giving the state thousands of miles of river bed land which it would not have owned under either the civil law or the common law, because the statutory definition includes all streams averaging more than 30 feet in width, whether or not they are navigable in fact. [5, p. 587]

Though the 1837 statute was supposedly an adaptation and continuation of the former Hispanic law to the effect that perennial streams are owned by the sovereign and expressly prohibit the making of surveys across navigable streams [4, p. 579; 64, p. 378], Mcknight contends that the historical assumptions on which the law was based were false. [64, p. 378] In Heard v. Town of Refugio [43; Also see 17] the Texas Supreme Court concluded that the earlier colonization laws of Coahuila and Texas merely implied such a prohibition, with subsequent retention by the sovereign of title to stream beds. Nevertheless, a later effort to question these conclusions 
proved unsuccessful in Mitchel1 v. Town of Refugio [74].

Even after the adoption of the common law in 1840 , the 1837 statute was retained and Texas courts have continued to apply the civil law rule, as modified by the act, to the effect that the beds of statutory navigable streams as defined therein are the property of the state. [4, p. 579] In Brown v. Linkenhoger [8]". . . . it was established that the state owns the beds of such streams from 'cutback to cutback.'" Unfortunately, the language of the statute is subject to different interpretations, and doubts over its proper construction have given rise to numerous problems which will be discussed in a later section. Suffice it to say, there may be both narrow, but navigable, streams which are considered to be in private ownership, and broad streams, which are not in fact navigable, in public ownership. $[102, \mathrm{p} \cdot 262]$

The determination of navigability of lakes is somewhat different from the statutory test used for streams. Here the test is whether the lake is navigable in fact, and if so, the state does own the beds of navigable lakes. In Welder $v$. State [137] a lake three and one-half miles long by two miles wide, with an average depth of four feet and covering approximately 5,000 acres, was found to be navigable. The Court observed that:

It is a reasonable rule that lakes large enough to be useful to the public for boating and fishing should be held to be public and not private property. [137, p. 873]

The court further noted that navigability tests should not be applied only to current uses, but to the lake's capacity for future use.

In Taylor Fishing Club v. Hammett [106], the Court found that a body of water one and one-half miles long and 700 feet wide, and with an average depth of fifteen feet, was not navigable, stating in the opinion:

- . it is not wide enough to provide a practical route for the transportation of commodities in any direction and does not connect any 
points between which it would be useful as a practical route of navigation. [And further] . . . the lake is useful for fishing and as a general pleasure resort, but it is generally held that a lake that is chiefly valuable for fishing or pleasure boats of small size is not navigable. [106, p. 130]

Thus, the purpose of navigation appears to be a more important consideration for lakes, though the dicta in Dincans $v$. Keeran [27] provides authority for a broader range of public use. [123, p. 41; 138, p. 9]

Stream Bed Ownership Under Common Law. The unmodified English common law rule is, simply stated, that land grants on streams above tidewater carry title to the thread of the stream, unless the boundary is fixed at some other location by the terms of the grant. [4, pp. 579, 585] (See F1gure 2, supra). This rule has not been followed in the United States and most jurisdictions have modifled it to retain public ownership of navigable streams, apparently combining the common law doctrine of sovereign control over navigable waters with the civil law rule of sovereign ownership of navigable stream beds. [87, p. 301]

As previously noted, Texas adopted the common law in 1840 , but has ignored the common law rule (and the various American modifications), continuing to apply the civil law rule, as modified by the 1837 statute, to the effect that beds of perennial and statutory navigable streams are the property of the state. [4, p. 579]

Despite this adoption of the common law, only those rules which were suitable to the environment of Texas and in harmony with the basic principles of Texas water law were retained. [4, pp. 578-79] The reasons for the retention of the civil law principles are explained by the Texas Supreme Court in Manry v. Robison [71]:

1) Much of Texas, like Mexico and portions of Spain, is an arid or semiarid region, where irrigation is highly desirable, sometimes a necessity, and access to water for its vast herds of livestock a 
matter of great importance. The civil law, therefore, which retained title to the beds of all perennial streams in the state, so that the impounding and distribution of waters might be better effectuated, was better sulted to our conditions than the rule of the common law. 2) Millions of acres of our lands had previously been granted under the Mexican law and the act of 1837. The continuance of the civil-law rule therefore avoided the conflict and discrimination which an application of the common law to grants made subsequent to 1840 only would have entailed. [Numbers added for clarity; 71, p. 447]

The generally accepted rule for nonnavigable waters is that the underlying beds are owned by the adjoining riparians, to the thread of a stream or the centerline of a lake. [102, p. 261] The property line is in the

center of a stream, sometimes determined as the line midway between its banks when the water is at its ordinary height, and sometimes the thread of the main channel. The methods of apportioning beds of privately-owned lakes and ponds is still more variable. [72, p. 794]

In determining the ownership of the beds of nonnavigable streams and the boundaries between properties along such streams, Texas does apply the common law rule, these points being established in Dutton v. Vierling [34] and Lee v. Gruppe [59].

Problems Associated with Statutory Navigable Streams. The 1837 statute relating to the survey of land lying on navigable streams and establishing the thirty foot rule reads as follows:

A11 lands surveyed for individuals, lying on navigable water courses shall front one-half of the square on the water course and the line running at right angles with the general course of the stream, if circumstances of the lines previously surveyed under the laws will permit. All streams so far as they retain an average width of thirty feet from the mouth up shall be considered navigable streams within the meaning hereof, and they shall not be crossed by the lines of any survey. All surveys not made upon navigable waters shall be in a square so far as lines previously surveyed will permit. [87, pp. 304-05]

The general appearance of surveys along or across watercourses is indicated by Figure 3. However, many surveys did not conform to this picture or to the dictates of Art. 5302. Jordan has noted that the directive to "front 
Figure 3. SURVEY LINES AND STREAMS
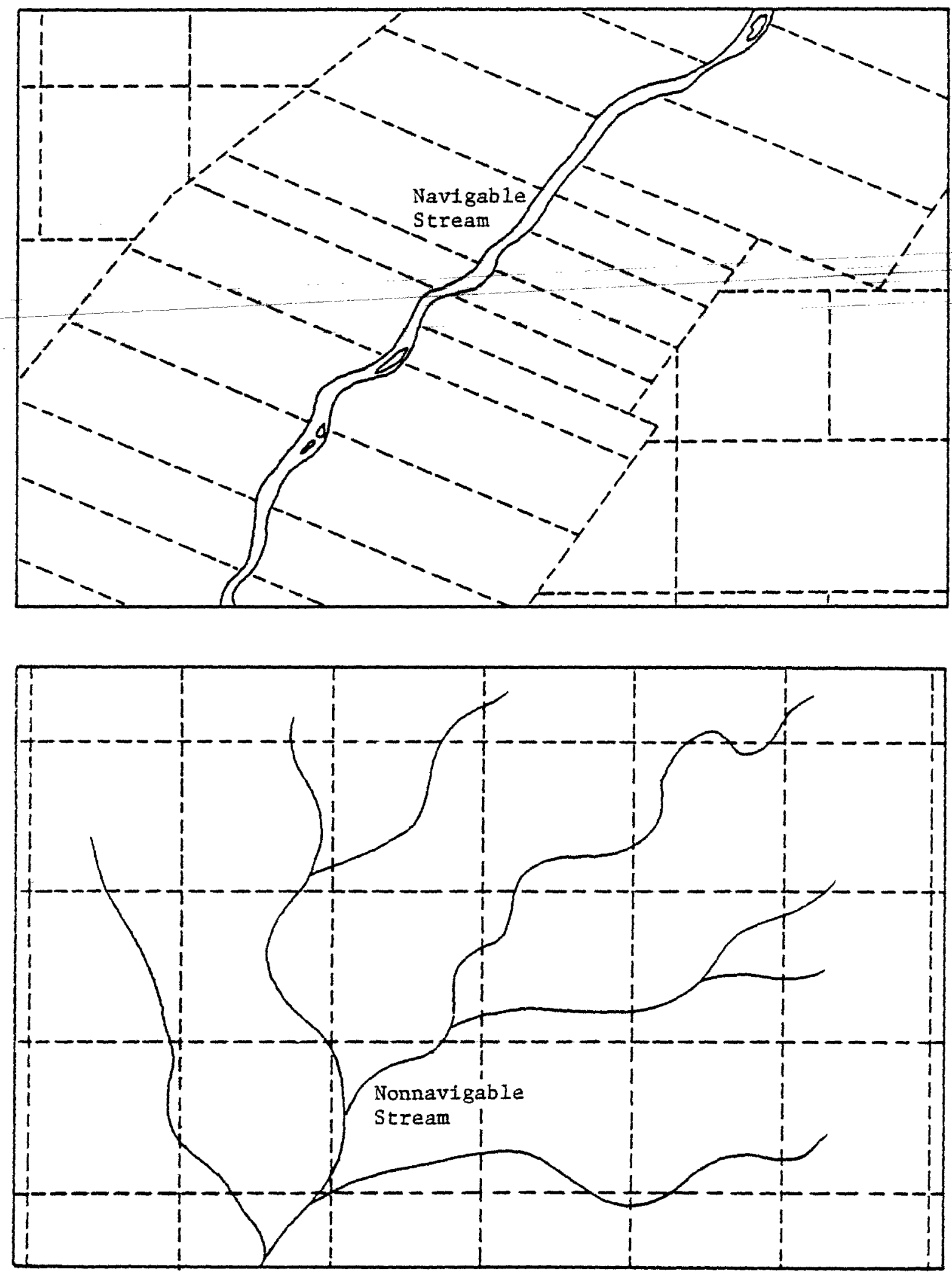
one-half of the square on the watercourse" produces a rectangular long lot four times as long as it is wide. [54, p. 76]

The apparent objective of this early act was not to regulate navigation, but was to prevent persons locating on the public domain from monopolizing the available water. However, the inevitable result of the statute is that streams of the stated width were made public and title to their beds was reserved to the Republic and the state, so that such streams, whether or not navigable in fact, have the same-legal quality and character as streams actually navigable. $[47, p .110]$

The 1837 statute does not void land grants which cross navigable streams as defined by the statute. City of Austin v. Hal1 [15] established that where the stream is thirty feet or more in width, title to the bed does not pass with the grant. However, title may have passed later to the riparian owners under the provisions of the Small Bill (Rev Civ Stat Ann, Art. 5414a) which relates to portions of stream bed lying within the boundaries of a survey [87, pp. 304-05] and the constitutionality of which was upheld in State $v$. Bradford [98]. However, according to a 1956 Attorney General's opinion, because the Small Bill provided that it ". . .shall not impair the rights of the general public and the state in the waters of streams," the general public was authorized to walk down the dry or submerged river bed which was privately-owned by virtue of the bill. [114, pp. 3,51

Roberts, author of the most meticulous study of Texas river bed ownership and boundaries, has summarized the implications for post-1837 land grants as follows:

1) Where the bed of a stream more than thirty feet in width is within or adjoins a grant issued after 1837 , title to the stream bed was re tained by the state and did not pass with the grant. 
2) Where a stream is less than thirty feet in width, grants bordering such stream extend to the center thereof.

3) . . . where the bed of a stream less than thirty feet in width is within a grant issued after 1837, title to the bed passed with the grant. [87, p. 305]

As previously noted, it is generally accepted that the 1837 act expanded on Hispanic law to include within the public domain all non-perennial streams thirty feet or more in width, and this fact is stated in several cases. Roberts, however, labels all such statements as dicta, and argues that unt1l the Texas Supreme Court rules direety on this question there is some basis for contending that the word "stream" used in Art. 5302 means only perennial streams, all non-perennial stream beds being owned by riparians. [87, p. 307]

Thus, the status of many intermittent streams and dry creeks in the drier western part of the state remains questionable. Hutchins notes that most streams only thirty feet wide and all such streams in the drier parts of Texas are not navigable in the common law sense, but may be within the statutory definition. [47, p. 110] Cases discussing the nature of streams indicate that there need not be a continuous flow of water, and that the stream may remain dry for long periods of time, but all relate to water rights and not stream bed ownership. [87, p. 308] In St. Paul Fire \& Marine Ins. Co. V. Carroll [89] it was determined that the statute is not applicable to ordinarily dry gullies, draws, and branches in the arid and semi-arid regions of Texas. Taylor Fishing Club v. Hammett [106] also established that Art. 5302 is applicable only to streams and not to lakes. [47, pp. 110-11] Roberts also discusses the status of streams navigable in fact, but which are less than thirty feet in width, concluding that though this issue has not yet arisen in Texas, it is largely academic since there are so few streams of this nature. [87, p. 305; Also see 111] 
According to Hutchins a federal court could not believe that the statute was intended to apply to land surveys on tidewaters, which though navigable, are not like streams. [47, p. 110] Nevertheless, a Texas court recently held that a coastal bayou which was enlarged by fishermen's airboats, innundating formerly dry private land in the process, was a navigable stream, and could not be crossed by the lines of a survey. The owner was held not to be entitled to the exclusive use of that part of the bayou covering his land, and could not fence it off. The Supreme Court, without offering Its own opinion, affirmed the lower court ruling. [58] However, Fisher v. Barber [37] reached a contrary result in that an owner of land which subsequently became covered with navigable water was held to have the exclusive right to hunt and fish in the waters covering his 1 and.

Roberts outlines several problems in the practical application of the rules of law relating to the thirty foot statute: 1) At what point on the opposing banks are width measurements to be taken?; 2) From what points on the stream is the average width to be determined?; 3) How is the average to be computed? First, Motl v. Boyd [76] and Heard v. Town of Refugio [43] provide authority for concluding that the "gradient boundary" of either bank establishes the points for measurement. The gradient boundary is also the dividing line separating private and public ownership on the bank, and its determination will be discussed in a later section. [87, pp. 311-12] On the second issue, Roberts believes that averaging that segment of the river bed adjacent to or within the particular grant in question is a much more reasonable interpretation than averaging the width of the stream from its mouth to the survey in question. He concludes that data for the latter methods are not readily available to landowners and surveyors, and its determination would require an inordinate amount of time, labor and expense. [87, pp. 312- 
17] However, he does note that the first method could result in division of a stream into alternating segments of statutory navigability and public ownership and nonnavigability and private ownership. Finally, regarding how the average stream width is computed, there has been no expression by Texas courts on the number of measurements that are required to be averaged. [87, p. 317]

Water Rights Adjudication and Navigability. To this point, all discussions of the navigability of Texas streans and the right of public access to them have turned on the interpretation of the language of particular statutes or cases. It has been shown that statutes, such as Art. 5302, are capable of different interpretations, and not all questions involving them have yet been resolved by the courts. The issues relating to the navigability of streams in the case law generally turn on the peculiar circumstances of each case, a piece-meal approach, making it difficult to derive general rules of conduct that the public and landowners can understand.

There is, however, the possibility of larger scale determinations on the issue of navigability and public access. This might be accomplished by the surface water rights adjudication currently underway in Texas, which is preceding slowly across the state from one watershed to another. [On the subject of water rights adjudication, see: $68,108,109,110,135]^{-}$

The Texas Water Rights Commission is now in the process of adjudicating water rights in the Upper Guadalupe segment of the Guadalupe River basin, and one of the issues is the navigability of the North and South Forks of the river in Kerr County, Texas, described in the Commission's final determination of water rights as follows:

In the course of adjudicating water rights in this segment the Commission determined the issue of navigability of the North Fork and the South Fork of the Guadalupe River. The issue of navigability was considered to enable the proper determination of other issues which are 
interrelated with navigability per se, specifically, the maintenance of dams and reservolis in and across the named tributaries and the use of water therefrom under the authority of Article 7500a (now Sect. 5.140, Texas Water Code [125], exempting certain small reservoirs from the permit requirement), or a valid riparian right. [129, p. 2]

In its determination, the Commission recognized the applicability of Art. 5302, the thirty foot statute, and also that the "gradient boundary" method is the proper way to measure the average width of the stream. However, the Commisston's findings were based on the measure of the average width of the water surface, a more restrictive (and also easfer) method than locating

gradlent boundary on the banks. Apparently, the average width of both streams was determined from their mouths (at their juncture) upstream through all water rights claims in the adjudication. It was found that the width of both forks was less than thirty feet for the first few hundred feet above their mouths, but that both had average widths of substantially greater than thirty feet above these constrictions. [129, pp. 2-3] After its investigation the Comission determined the following: - . the North Fork and the South Fork of the Guadalupe River are navigable watercourses from their mouths up to the area in any clatm asserted in this adjudication. As a result of this conclusion, no dam or reservoir constructed in the bed of the North Fork or the South Ford of the Guadalupe River is within the provisions of Section 5.140, formerly Article $7500 \mathrm{a}$, and prior statutory authority, which exempt such a structure from the requirement of obtaining a permit or other legal authority. . . . In addition, the maintenance of any dam and reservoir on the North Fork or the South Fork of the Guadalupe River which was recognized as a part of a riparian right must not unreasonably impair the public right of navigation and access to and enjoyment of a navigable watercourse. [Emphasis added; 129, p. 3]

Though it is too soon to fully assess the full import of the Commission's action, it should be evident that such a sweeping declaration of navigability could have a most significant impact in determining the nebulous status of particular Texas streams with respect to public access. To this point in the adjudication process, this is the only river segment in which navigability has been investigated, and it is obviously a highly 
controversial and emotion-charged issue. It was reported that the Commission overruled the recommendation of its own Hearing Examiner that this determination not be made, and that several water rights claimants in the adjudication are contesting the Commission's findings. [128c, p. 1] It is also reported that there will shortly be a ruling in the adjudication proceedings on the question of statutory navigability of Texas streams. [1281, p. 1]

Use of Banks and Shores

Certainly one of the most perplexing and perhaps the least settled aspect of public rights on Texas' navigable waters is the right to use the banks and shores. Here the time when the original grant was made is pivotal, more specifically whether it was before or after 1840 , the date when Texas adopted the common law. [123, p. 43; 138, p. 10] Pre-1840 grants are governed by the civil law of the Hispanic sovereigns and the Republic, and post-1840 grants are controlled by the applicable common law.

The Texas Supreme Court in State v. Grubstake Investment Assn. [99], recognized that title to riparian land granted by Coahuila and Texas in 1835 was burdened by certain public servitudes. Later, in Diversion Lake Club v. Heath [31], the Court, though indicating it was unnecessary and dicta, recognized that public rights to use the banks and shore were quite different under the civil law and common law, stating:

One of the laws of the Partidas provides: And although the banks of rivers are, so far as their ownership is concerned, the property of those whose lands include them nevertheless, every man has a right to use them, by mooring his vessels to the trees, by repairing his ships and sails upon them, and by landing his merchandise there; and Eishermen have the right to deposit their fish and sell them, and dry their nets there, and to use said banks for every other purpose like those which appertain to the calling and trade by which they live. $[31, \mathrm{p} .447]$

The uses mentioned in the Diversion Lake Club case and also in Dincans v. 
Keeran [27], i.e., hunting, fishing and camping, are the servitudes spoken of in the Grubstake case, according to a 1953 attorney general's opinion [113]; later, another attorney general's opinion [114] echoed the belief that the public has the right to make use of the shore under the civil law. [123, p. 43] All statements regarding public use of the banks and shores under the civil law are merely dicta or lesser authority such as attorney general's opinions, while the common law rule in these matters appears better settled. [123, p. 43$]$

In direct contrast to the clvil law, the apparently universal common law rule is that persons using a stream have no right to use the foreshore which is in private ownership or the banks where they are not riparian owners. [123, p. 43; 138, p. 10] The Diversion Lake Club case established that in Texas the public has no right to go beyond the line dividing public and private ownership without the consent of the riparian landowner. [46, p. 97] A possible exception may exist where temporary use is made of the bank or shore in cases of peril or emergency. This question remains unsettled in Texas, and was specifically left open in the Diversion Lake Club case. [123, p. 43; 138, p. 10] Regarding the banks and shores of lakes, it was also determined there that the public had no right to use the banks of a lake which lay beyond the original banks of the stream, following impoundment of the lake's waters, and which were the private property of the riparian owner. [46, p. 97]

Under the common law, the dividing line between public and private ownership of a stream bank is the gradient boundary as established in Oklahoma v. Texas [82], the prolonged interstate dispute over the Red River boundary between the states. Since that time Texas courts have uniformly held that the gradient boundary is the proper dividing line and in determining owner- 
ship of stream beds and banks (as opposed to their use) it is applicable to all Texas land grants, regardless of whether they date from before or after 1837. [87, pp. 309-10] The boundary is defined as "a line located midway between the lower level of the flowing water that just reaches the cut bank and the higher level of 1t that just does not overtop the cutbank." [123, p. 43]

The common law gradient boundary is much more restrictive of public use than is the civil law rule. Roberts notes that it gives riparlan landowners a maximum amount of land with the state retaining a minimum amount for the public. [87, p. 310] In the Diversion Lake Club case the Court observed that, "The civil law rule is, we think, more favorable to public ownership than is appropriate to our conditions." [31, p. 447] Hawkins a1so argued for severely limiting the public use and interest in west Texas watercourses:

Thousands of acres of river bed soil, under the construction given to the statute (Art. 5302) in Mot1 v. Boyd, in the arid and semi-arid portions of the state do not have characteristics different from the usual upland in that area. The use of the water in that area is not for navigation, transportation or commerce; the waters there have little use except for private purposes. Consequently, the purposes for retention of the soil, to promote the division of waters and use of the waters for transportation purposes, fishing, etc., are entirely lacking, . . [42, p. 514]

As previously noted, the banks and shoreline of Texas streams are a1most invariably privately-owned, and the inability to readily distinguish between pre-1840 and post-1840 land grants leaves the situation even more ambiguous. A recreationist who steps out of a navigable stream onto the bank above the line dividing private from public ownership, or above the gradient boundary, may be guilty of trespass. [117, p. 8] This line cannot be readily located in practice, and it has been said, not totally in jest, that: 
- . to locate that line, a canoeist needs a lawbook, a copy of the original land grant, a surveyor's instrument, and five justices from the Texas Supreme Court. [11, p. 39]

Suffice it to say, in most situations encountered on Texas streams, the recreationist should err on the side of caution, and perhaps keep in mind only the more restrictive dictates of the common law rule. Nevertheless, on some more isolated streams like the Rio Grande, the banks and shores are occasionally used for such purposes as camping, as indicated by this statement:

Bermuda grass flats on the banks can be used for overnight camping; technically these are privately owned, but the Rio Grande is a world of its own. For that matter, you can camp on either side of the river; no Mexican customs official is likely to scale down the cliffs to ask for your tourist card. [3, p. 36]

Locating the Boundary Between Public and Private Ownership. Most of the cases which recognize the gradient boundary as the boundary between public and private ownership on Texas' navigable streams are not very informative or specific about its description and location. Arthur Stiles, the originator of the method, has discussed its application in a law review article that is said to be,". . so clearly set out in non-technical terms that it can be understood and followed by lawyers as well as engineers and surveyors. [101, p. 305] But, Roberts credits most surveyors with feeling that the correct line is ". . difficult and sometimes impossible to locate on the ground." $[87, \mathrm{p} .310]$ Hawkins made a cogent observation about the problems associated with establishing riparian boundaries:

It is relatively easy for a court or lawyer at the courthouse or office to define in language the true boundary between private riparian lands and the beds of streams reserved to the state. It is not difficult to adjudicate that the bed of a stream is owned by the state and that the banks are owned by the adjacent riparian owners; that the bank of a stream is at the outer margin of the bed, or that the bed lies within the inner margins of the banks of a stream; that 
the boundary between such private and public lands is on a line separating the banks from the bed of the stream. But armed with such a rule no two men or surveyors in the field would agree upon the actual location of the boundary upon the earth's surface. [42, p. 502]

Stiles describes how finding the "lowest qualified bank" for each seg-

ment of the stream is essential to establishing the boundary:

The boundary is set at the mid-height point of the lowest qualified bank in the vicinity where the water, rising against the bank, will first overflow it. But until this bank is found, the height and position of the boundary are unknown. Therefore, finding and marking this bank conclusively locates the gradient boundary upon the ground for the first time. Thence the boundary runs on and along the bank as a gradient of the flowing water in the river. [101, p. 310]

He also distinguishes between accretion and erosional banks, maintaining

that normally only the accretion bank can be used to establish the boundary, the height of which is then transferred across stream to the opposite

bank. The characteristics of an accretion bank and how it may be recog-

nized are described as follows:

The accretion bank has these features. Between the top of the bank and the rising ground beyond, there is a slight depression somewhat paralleling the river but not a part of the river and in no sense a "by pass" or slough. Near the head of this depression is a minute "divide" frequently discoverable only with an engineer's level. This divide is the exact top of the bank. The rising water in the river, upon reaching the top of the bank barely overflows it. Thence the water flows down the depression and returns to the river in a different place. This topographic form marks the typlcal accretion bank and sets it apart from the erosion bank and the transverse slope against which the water rises to an uncertain height and then recedes over the same ground. [101, pp. 314-15]

The boundary can only be located by diligent fieldwork, according to

Stiles, and cannot be derived from secondary sources:

The lowest qualffied boundary bank can be found only by close study in walking along the banks, not by inspection from a distance, from the air, from across the river, or from a few isolated places most easily reached by automobile. No intelligent idea of the river can be had from survey diagrams, aerlal photographs, or contour sketches made from them and examined in some office. Such procedures result in superficial knowledge, false impressions, wrong conclustons, and bad work. Finding this bank means hard work on foot on the river. [101, p. 316] 
He gives several examples of how the gradient boundary was determined for specific stream segments. To obtain these calculations it was necessary to survey both sides of these rivers for a distance of five to ten miles. In none of the examples, which include such major streams as the Colorado River, was the lowest qualified bank more than 3.22 feet above the normal water level. This gives a mid-point height of only about 1.6 vertical feet above the base of the bank dividing public and private ownership. Figure 4 illustrates in a hypothetical and very general way the location of the gradient boundary. Though it is obvious that the appearance may vary greatly from one location to another, the author trusts this hypothetical example will not lead to "false impressions and wrong conclusions." The measurements cited above illustrate the very limited portion of the lower river bank which the public can use without trespass. It should also be noted that during periods of high flow the boundary may already be innundated. Application of the common law rule would appear to be so very restrictive as to preclude almost any use of river banks for such purposes as fishing or camping.

Stiles also discusses the problems of trying to establish gradient boundaries on intermittent streams where the gradient of flowing water is usually not available for reference. He notes that traces left by the receding water such as "deposits of scum, silt, sand, drift and litter" can be utilized as a preliminary reference point, though final determination of the boundary must await stream flow. [101, p. 322]

It should be clear from this discussion that, however desirable it might seem, it would be utterly impossible to survey and permanently mark the ownership boundaries on all navigable streams in Texas so that both the public user and the riparian landowner could be sure of their location at 


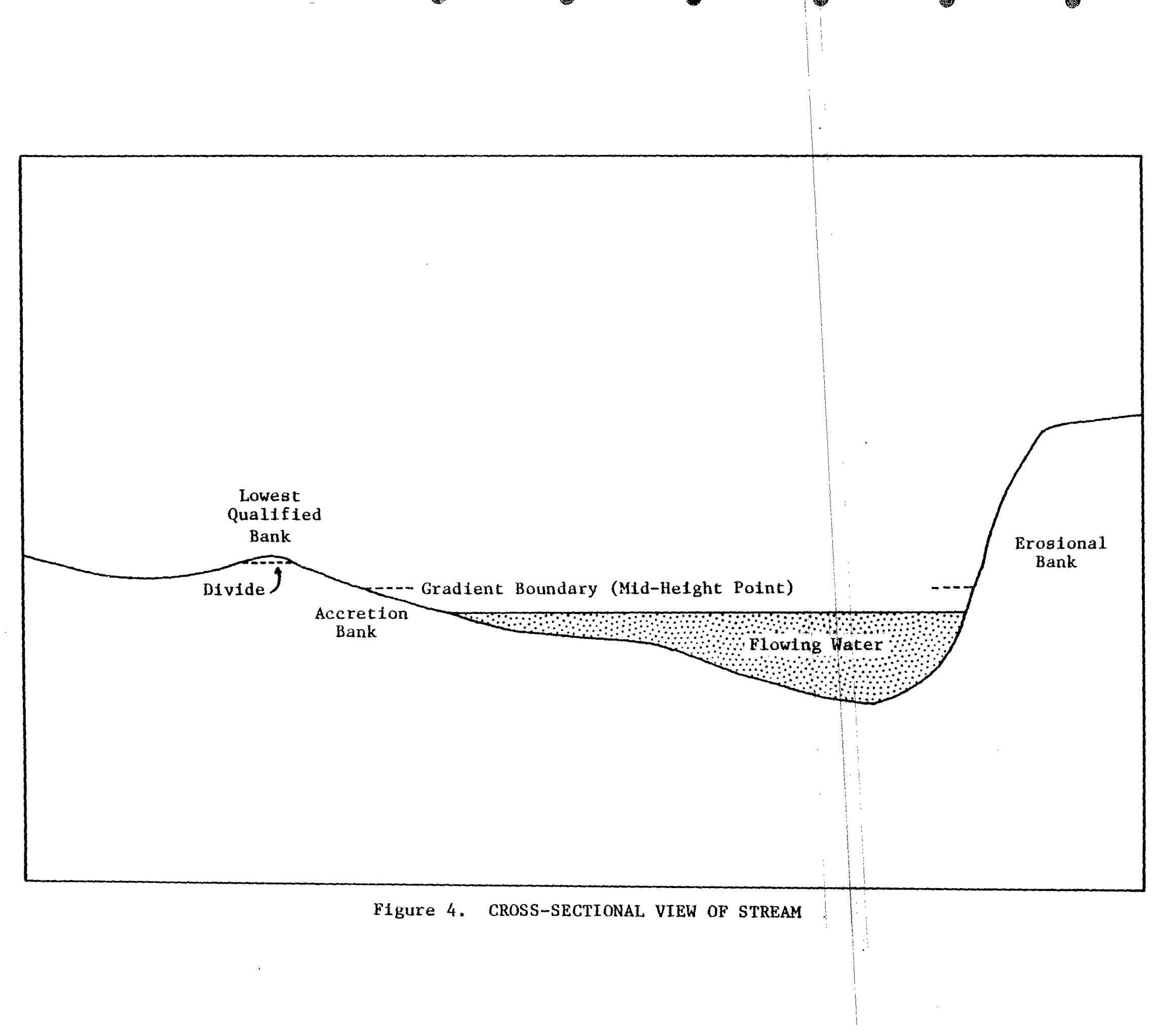


all times and places. Even if the establishment of such a highly visible boundary were possible, it is recognized that the boundary itself is subject to constant change and modification as the stream erodes and deposits material along its course. Hawkins makes a critical distinction between the location of thls changing boundary for purposes of public use and the test for the ownership of the stream bed itself:

It ought to be clear, at least in Texas, that the test of navigability of a stream in the sense and for the purpose of determining ownership. of the bed, Is entirely independent of and in no maner based upon any test defined by the courts for determining the navigability, publlc or private character of a stream for other purposes. The test of navigability, in respect to the ownership of the bed of a stream is statutory and unchanging. [42, p. 507]

Beaches and Tldal Waters

In searching through the literature pertaining to public access to wa-. ter, the author was quickly made aware that most of the available material on the subject relates to coastal or tidal waters. ${ }^{2}$ Also, the case law and statute law regarding access to coastal waters is much more clearly defined than are rights of access to inland waters in most jurisdictions. Most coastal states have already established that certain portions of their beaches are owned by the public and thus are open to public use.

In Texas, the courts and legislature have recognized the right of pubIic access to beaches to be the public policy of the state. Rights of ingress and egress are based on two traditional common law principles:

1) The public may establish a presciptive right to cross private property to reach the state-owned beach through long and continued use.

2 Among the most helpful general studies are Brower, et al, Access to the Nation's Beaches: Legal and Planning Perspectives [7] and Dewsnup, Public Access Rights in Waters and Shorelands [26]. Other useful studies include Crandall [23] and Neuman [78]. Bibliographies which pertain primarily to beaches and coastal waters include Ditton [28; 29], Heifoff [44] and Owens [83]. 
2) The landowner may impliedly dedicate his land seaward of the vegetation line to the public by acquiescing to continued encroachment and by benefiting from public maintenance of the beach. $[9, p .7 ; 123, p .42]$

The dicta in Dincans v. Keeran [27] Indicated that hunting, camping and fishing are reasonable uses of the Gulf coastal waters and shoreline, similar to the public rights recognized for inland waters. Though the landowner can prevent persons from trespassing on his property for the purposes of hunting, camping and flshing, he cannot prevent the public from entering the enclosed shoreline for these purposes. [46, p. 98]

Texas is one of several states which have expanded on the common law principles, mentioned above, by allowing members of the public to use the privately-owned portion of the beach, which extends seaward from the line of vegetation to the line of mean high tide. Also, it was the first state to recognize and protect the public's right to use and enjoy the privatelyowned portion of the beach. [5, p. 581; 9, p. 7]

In addition to the common law principles established in Texas case law, there is also specific statutory authority affirming and protecting the pubI1c right of access to ocean beaches. [5, p. $581 ; 46, \mathrm{p} .98 ; 95, \mathrm{p}$. 2] In July, 1959, the Texas Legislature passed an Open Beaches Act (Rev Civ Stat Ann, Art. 5415d) almed at keeping developers and landowners from blocking off sections of the beach in front of their land and making it into a private beach. [95, p. 2] The act declared the public policy of the state to be as follows:

- . the public, Individually and collectively, shall have the free and unrestricted right of ingress and egress to and from the stateowned beaches bordering the seaward shore of the Gulf of Mexico, or such larger area extending from the line of mean low tide to the line of vegetation bordering the Gulf, in the event that the public has acquired a right of use or easement to or over such area by prescription or dedication or has retained a right by virtue of continuous right in the public. [46, p. 98] 
Despite the fact that the common and statutory law are much better defined concerning the right of public access to beaches, some problems remain, specifically the necessity of passing over private land without trespassing to reach the public portion of the beach, though once there, there is usually no problems with the public moving up and down the beach. [7; 18, p. 3] Any such public right is a dominant interest in the affected property, and neither the landowner nor the state can diminish this right. [9, p. 7] Recently, a controversy has arisen over the Gity of Galveston's attempts to regulate vehicular traffic on beaches within the city limits. [95, p. 2] Though the Open Beaches Act authorizes cities and counties to regulate traffic on beaches bordering the Gulf of Mexico, those acting under this provision will violate public rights if they close the beach to traffic without insuring the availability of alternate means of access. [9, p. 7] Galveston has attempted to answer this problem by providing pay parking access areas. [95, p. 2] Brower, et a1, [7] have found that the simple provision of public walkways leading from a street or road to the public shoreline can greatly expand the public use of the beach. Another method is to place portions of the shore in public ownership, and state and federal governments have acquired a number of seashore sites for public parks and recreation areas.

Unfortunately, the common law principles of prescription and dedication which have been relied on to give the public the right of access to beaches have been found largely inapplicable to inland waters. In only the most exceptional circumstances is it likely the public has crossed private property in approximately the same place for a long period of time. Nowhere on inland waters is there a lengthy history of massive public takeover of private property to compare with public use of the Gulf beaches. A summary of law 
applicable to public access concludes, "It is clear that prescription as a general princtple will not be sufficient to establish public access rights to Texas rivers." [123, p. 42] The summary further states, "As for dedication, actual or implied, it is equally clear that landowners have been far more hesitant to permit public trespassing for the purpose of gaining access to rivers than were Gulf Coast landowners about allowing the public to reach the state-owned beach." [123, p. 42] Neither is there any statutory provision for inland waters which is comparable to the Open Beaches Act, though some authorities belleve that the suggested Texas Public Rivers Act, which recently failed legislative passage, would have accomplished the same result. [See 5] 
CHAPTER III

PUBLIC ACCESS TO WATER IN OTHER JURISDICTIONS ${ }^{1}$

It was the author's original intention to investigate water law and problems relating to public access in other jurisdictions much more thoroughly; but as this study progressed, it became fincreasingly apparent that most situations and legal precedents in Texas are relatively unique, which does not make for ready comparisons with other states. Because Texas land and water law has a strong element of Hispanic civil law, combined with the unusual statutory test of stream navigability and the 1ater common 1aw, and due to the fact that it was once an independent republic, retaining its public lands upon admission to the Union in 1845 , it is indeed unique among the states. Therefore, this chapter contains a much more limited coverage of the law of public access in other states, focusing instead on emerging trends in these states, as well as some discussion of federal legislation and agencies which may affect the public use of Texas lakes and streams. Johnson and Austin have observed that differences among the states concerning surface use of streams and lakes (such as recreational use) do not correlate very well with the notable differences in consumptive water

${ }^{1}$ A wide-ranging and very thorough comparative analysis of public access law in the United States is Stone's chapter, "Public Rights in Water Uses and Private Rights in Land Adjacent to Water," [102] in the seven volume Waters and Water Rights. More limited coverage is found in Chapter VI on "Water-Based Recreation" in Meyers and Turlock's water resource management casebook [72]. Dewsnup's Public Access Rights in Waters and Shorelands [26] pertains more to the coastal zone than to inland waters. More limited surveys are by Curtis [24] relating to the eastern United States [also see 33; 133; 134], and by Simmons [93] and Johnson and Austin [53] for the western states [also see $19 ; 20 ; 35]$. 
use, which basically relates to the application of the appropriation water rights doctrine in the West and the riparian doctrine in the East. [53, pp. 1-2] Nevertheless, for convenience sake, the country will be divided in half and public access trends will be examined in terms of the eastern states and western states. In most respects the situation in Texas is probably more comparable to the latter.

Public Access Trends in the Eastern States

It has already been recognized that American jurisdictions rejeeted the English common law rule of nonnavigability above tidewater, developing instead the commonly used "navigability in fact" test. In most eastern states an inland stream must be navigable in fact for a public right of access and enjoyment to be asserted, though the rationale supporting this rule varies considerably from state to state. The effect is to accord the non-riparian public a share in the use and enjoyment of a river or stream that otherwise might be largely monopolized by private owners along its banks. Again the nature and extent of permitted uses, and the criteria for designating rivers or streams as navigable, vary markedly. [24, p. 9]

The result is a court-created dichotomy of public and private rights of use. Figure 5 illustrates the basic legal controls that surround and constrain the establishment and exercise of these rights. The dividing line separating private and public rights is subject to constant change as rights are asserted or lost by either group. Waite has been critical of this division but used it, nevertheless, stating:

In spite of the fallacles and detrimental effects inherent in placing permitted water uses in two groups labeled either "public" or "private," the distinction is still made in the cases, and lawyers customarily speak of the permitted uses as rights. [133, p. 11]

Curtis contends that the conflict inherent in this division is not serious and argues that there is probably more dissension among non-riparians in 
Figure 5. BASIC LEGAL CONTROLS AFFECTING PUBLIC ACCESS RIGHTS

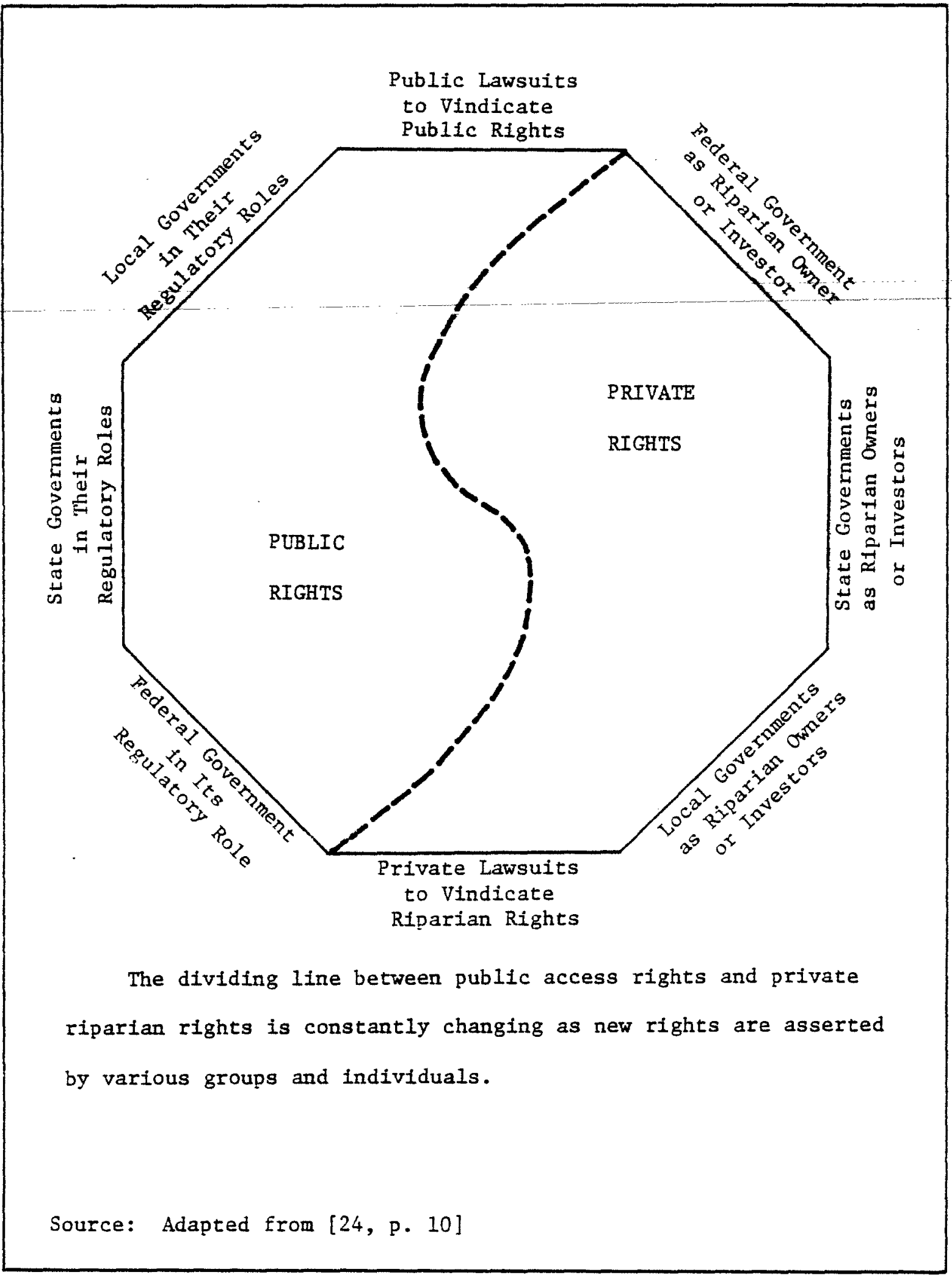


asserting incompatible public rights than there is between riparian owners as a group vs. the public as a group. [24, p. 9; also see 33] This view is supported by Countess et al:

Competition among recreational activities is apparently intense on certain popular streams in the eastern United States. Of particular note are conflicts between boating (canoeing and kayaking) and fishing enthusiasts. The degree of conflict is usually a function of space, time and individual philosophy. Other conflicts include fishing vs. swimming and boating vs. swimming. [22, pp. 149-50]

They also note that few eastern states have attempted to manage river recreation through such regulatory measures as limiting particular activities or zoning. Surprisingly, despite the increasing populartty of river recreation in the East and the growing need for some controls, it was found that river recreation was considered to be of minor importance by state recreation and water agencies, and a majority of the states had no data on the relative importance or significance of stream recreation in comparison to other outdoor activities. [22, p. 150]

The scenic or conservation easement has frequently been used as a device for controlling unwanted development and retaining the natural quality of desirable land along some eastern streams. Predictably, reaction from riparian property owners immediately influenced by the restrictions has been negative, and they consider such easements as ". . an unwarranted and unjustified encumbrance on their Iand." [22, p. 148]

\section{Public Access Trends in the Western States}

The western states possess certain general similarities in that: 1) Excluding Texas, they were all carved out of the public domain; 2) They are generally less populous than the eastern states and most have placed more emphasis on the importance of outdoor recreation; and 3) Most contain arid or semi-arid regions. [53, p. 1] Yet, despite the relative lack of population pressure on recreation resources, the dry climate of much of the region 
Iimits the number of navigable streams. Even though there are usually numerous access points through the extensive federal lands (unlike Texas where practically all property is privately-owned), there is still the feeling that the public is often denied access to use surface water resources.

In most western states, the scarcity of water has given rise to the long-established custom that the limited water supply had to be put to beneficial use, which normally meant only consumptive uses such as for irrigation. However, there is some evidence that the institutional structure is gradually changing to reflect the view that instream surface water uses such as for recreation are also proper beneficial uses. [91, p. 1]

There appears to be almost complete uniformity among the western states regarding the right of public use on waters where the state owns the stream bed. In all the western states, except for Colorado, the courts have held that the public has a right to use such navigable waters for fishing, commercial travel, recreation, and otherwise. The early cases tended to lump together both the issue of stream bed ownership and the right of public use. If the state owned the stream bed, then the public had a right of use; if the bed was privately-owned, then there was no public right. [53, pp. 34, 36]

Usually only the larger streams of the West have been declared navigable. These encompass streams which were meandered or surveyed during the original government surveys of the western public domain, and include such streams as the Missouri and the Yellowstone. Another basis for finding a stream navigable is its ability to support commerce and the transportation of goods to market, at least on a seasonal basis. Many of the larger western rivers did at one time support some commerce. [90, p. 33]

Another test of navigability appears to be slowly emerging, which might eventually have the effect of opening still other western streams to the 
recreationist and sportsman. This new test has to do with the ability of the stream or lake to provide diversified recreation for the public. In Idaho, Silver Creek was recently declared to be navigable because ". . . it has been navigable for years and has been used for boating in connection with just the pleasure of seeing the area and for fishing, trapping, gaming and fowling." All the land along its bed and banks were opened to the public up to the high water mark, thus allowing sportsmen to walk along the lower stream bank in most seasons, as well as float the river. $\{90, p, 3\}]$ A Montana decision designated the Gallatin River as navigable, and thus open to the public, apparently more because of its past and present ability to support commerce rather than for its recreational potential, and only the land below the low water mark was considered in the public domain. [90, p. 33] However, if these trends continue, recreationists in the West may eventually be able to enter a stream at a public access point and then wade or float to the next public access point without fear of trespass. Though the right of public use is established on state-owned streams in the West, some states also give some recognition to varying degrees of right in the public or other riparians to use small streams and lakes where the bed is privately-owned. This is said to be based on the common law notion that society's needs require a public right of use, essentially for recreation. $[53, \mathrm{pp} .8,38]$

They conclude that despite the growing number of cases involving public access to water in western jurisdictions, the number is still quite small compared to cases involving water rights or consumptive water use, and they note,". . . the field is sufficiently new so that most development lies in the future." However, rapidly expanding population in the western states and increasing recreational demands seem to assure that the 
number of conflicts involving surface use of water will increase proportionately. [53, p. 52]

\section{Federa1 Legislation Affecting Water-Based Recreation}

Though the federal government has immense power over water resources through such provisions as the commerce clause of the U. S. Constitution, in most cases the full constitutional powers are not exercised and most water rights and water use problems are left to the various states. However, at the federal level, there are several acts which do affect, in one way or another, recreation on rivers and lakes. The more specific impact on public access to water can usually be only inferred rather than addressed directly.

A number of federal agencies have the implicit capacity to significantly affect water recreation. For example, the Federal Power Commission, the U. S. Army Corps of Engineers, the Bureau of Reclamation or the Soil Conservation Service, among others, have authority to license, sponsor, or undertake water resource projects which ". . .could convert a free-flowing stream into a reservoir, a concrete channel, or a cooling tank." [93, p. 34] It has been noted that there has been a tendency to ignore in federal water development and navigation projects the impact on recreational activities. The U. S. Army Corps of Engineers and the Bureau of Reclamation have been particularly active in Texas water resource development, the later agency having created some twenty-eight dam and reservoir projects in the state. The Federal Water Project Recreation Act of 1965, intended to encourage states and other non-federal public agencies to develop recreational facilities on federal project reservolrs, has not met with great success. Largely because of federal control, many states and local agencies have been reluctant to share in federal reservoir recreation costs. [67, pp. 6-7] Other such diverse pieces of federal legislation as the Federal Water Pollution Control Act and 
the Endangered Species Act, may also have some impact on water resource use and development and consequently on water-based recreation. Among acts recognized as having a more specific impact on recreation is the 1964 Wilderness Act. While not specifically directed at rivers, it does contain provisions restricting federally-funded water resource projects, and does apply to rivers within designated wilderness areas. Lands, and the rivers they include, set aside under the act are to be undeveloped, representative examples of pristine natural ecosystems, where man is ".... a visitor who does not remain." [93, pp. 33-34] The National Wilderness Preservation System created by the act contains land administered by the U. S. Forest Service, National Park Service, Fish and Wildlife Service, and more recently, by the Bureau of Land Management. Currently, 14.4 million acres are in the system, the vast bulk being located in the western states. $[96, p \cdot 81]$

Most of the provisions which have been discussed are relatively marginal controls on water resource use and development affecting recreation. The greatest potential impact for federal recreational management of streams is contained in the National Wild and Scenic Rivers Act of 1968. National Wild and Scenic Rivers System. In 1968, Congress passed the National Wild and Scenic Rivers Act which recognizes the need to preserve some of the nation's few remaining natural, free-flowing waterways for their cultural values and potential recreational uses. Provision was made for inclusion of rivers or sections of streams of national significance in the Wild and Scenic Rivers System, where they will be protected and preserved in a basically undeveloped, or at least lightly-impacted, state. $[84$, p. $29 ; 127$, p. II-98]

The act designated eight river segments to be included initially within 
the system, and further, identified some twenty-seven other streams as having segments believed to be promising candidates for future inclusion. New rivers can be designated by specific congressional legislation, or by admin- . istrative action by the Secretary of the Interior, provided certain nomination procedures are met by the states and provided the cost of administration will not be borne by the federal government. [84, p. 29] Figure 6 illustrates those streams in the United States which are a part of the Wild and Scentc River System.

Three categories of rivers are recognized by the act: 1) wild, 2) scenic, and 3) recreational. A single stream may have segments in one or more of these categories depending on the amount of human impact. In addition to being essentially free-flowing and unencumbered by impoundments, rivers in the system are expected to be non-polluted and free of major human impacts in the immediate vicinity of the stream banks. The "recreational" category permits the greatest amount of human impact and development to be present. [84, p. 29]

Unlike most types of federal land management, such as parks and forests, wild and scenic rivers tend to be made up of narrow, riverine corridors, a configuration expected to continue in the future. "The practicalities of land acquisition cost, administration, and acceptability of river designation by local land owners favor this approach." [84, p. 29] Among devices used to reduce land acquisition costs are "scenic" or "conservation" easements. Such easements permit landowners to retain already established compatible uses and occupancy of their lands, and hold displacement of residents to a minimum. [84, p. 30] However, opposition to such measures has already been noted. The wild and scenic rivers act prohibits any federal or federally-assisted water development projects which would directly and adversely affect the 


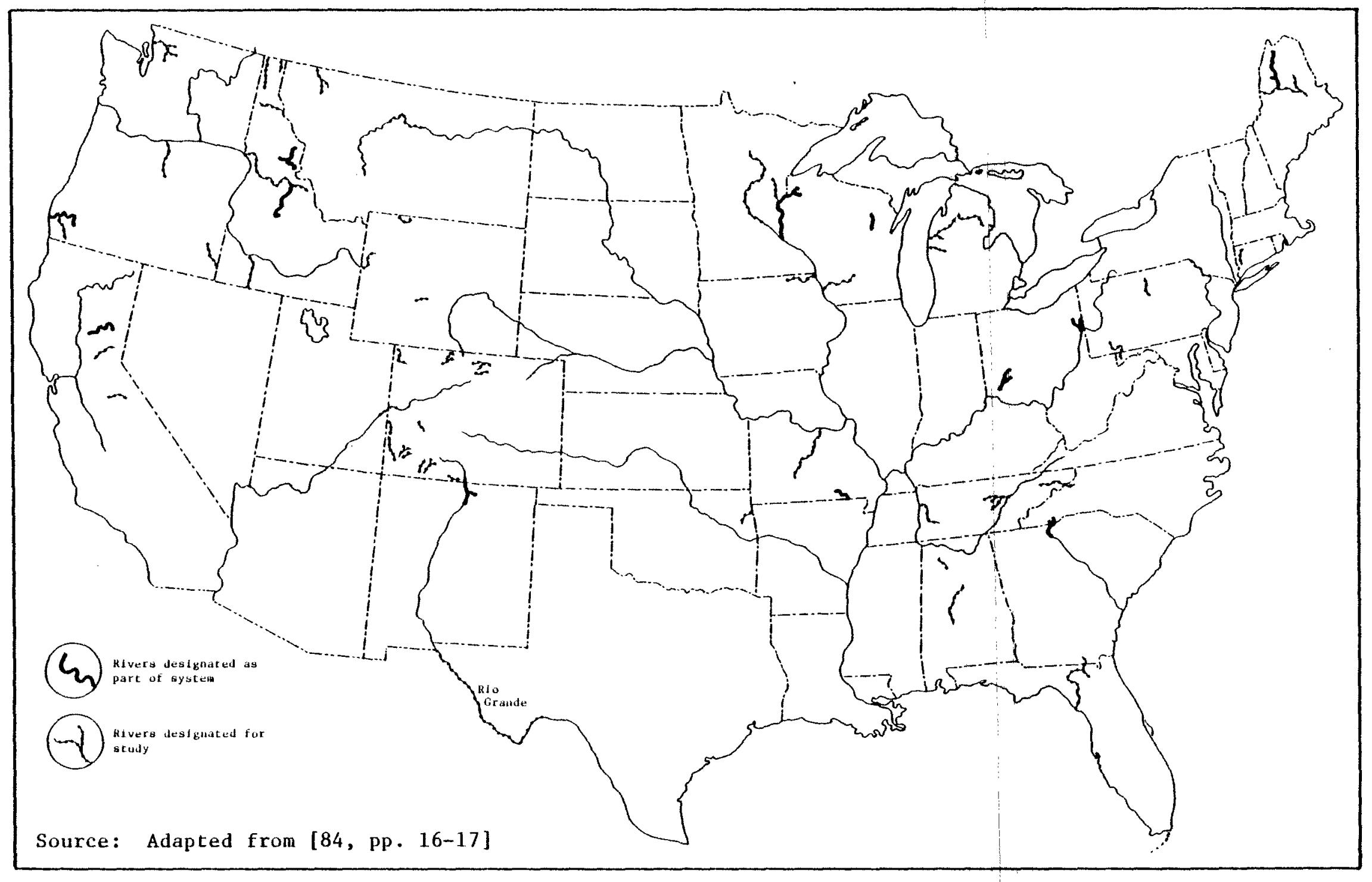

Figure 6. U. S. WILD AND SCENIC RIVER SYSTEM

只 
designated component of the system, and also extends the same protection to rivers on the study list for the duration of their study period. [84, p. 30; 93, p. 33]

The Bureau of Outdoor Recreation is the federal agency responsible for coordination of the Wild and Scenic Rivers program, conducting many, and coordinating all, of the studies undertaken pursuant to the act. On the other hand, administration of the designated segments is accomplished by the National Park Service, the U. S. Forest Service, or occasionally, the Bureau of Land Management. The study of proposed rivers must be conducted in cooperation with the states and they should contain a determination of the extent to which the states might participate in the preservation and administration of the segment. [84, P. 30] The act does not affect most of those aspects of state jurisdiction which relate to fish and wildlife law, water law or stream bed ownership. [93, pp. 33-34]

It is not surprising, given the general absence of federal land ownership and the degree of waterway development in Texas, that the Rio Grande was the only Texas river segment specifically listed for possible inclusion. Though President Carter also proposed adding that portion of the Guadalupe River in the Hill Country above Canyon Reservoir, this suggestion attracted no local support and a considerable amount of opposition from such groups of property owners as the Upper Guadalupe River Association. [5, p. 592; 45, p. 74; 128f, p. 3] The study of the Rio Grande from Alamito Creek near Presidio to the International Amistad Reservoir was directed by the Bureau of Outdoor recreation in cooperation with the U. S. Forest Service, National Park Service, International Boundary and Water Commission, and the Texas Parks and Wildife Department. These agencies released a final draft environmental impact statement in 1976 which proposed inclusion of a segment of 
the Rio Grande in the National Wild and Scenic Rivers System, which would place the Texas side of the river under the management of the National Park Service. [127, p. II-98] It should be noted that the National Park Service, in its administration of Big Bend National Park, already exerts some control over river recreation on the Rio Grande, refusing to issue floating permits during periods of high water flow in the deep canyons along the park boundary. $[86$, p. 20]

The proposed designation of the Rio Grande as wild and scenic also at-tracted considerable opposition. [128h, p. 4] A representative of the Tourist and Travel Committee of the West Texas Chamber of Commerce, noted that, "Some provisions of the Wild and Scenic Rivers Act could limit access to the river by certain segments of the public, and any future development in the area would be ruled out as a practical matter." [Emphasis added; 112, p. 6-A] The chamber contended the overriding issue to be that the affected landowners and West Texas residents would be barred from making future decisions over the area's development. Nevertheless, despite such opposition, the House recently approved the $\$ 1.6$ billion Omnibus Parks bill, which includes designation of a 191.2 mile stretch of the Rio Grande as "wild and scenic" and assures its inclusion within the system. [128j, p. 4] 
CHAPTER IV

GAINING ACCESS AND IMPEDIMENTS TO ACCESS

The previous chapters have attempted to examine and generally summarize the less than concrete water and property law which relates to the problems of public access to water; to sumarize the legal trends relating to public access in other jurlsdictions; and to briefly review some of the applicable federal legislation which deals with the recreational use of water. This chapter continues the legal-spatial analysis of the problems of gaining access to public waters in Texas, reviews the kinds of access points which the public may find available, and, once access is obtained, the various impediments the public can reasonably expect to encounter on most streams and some lakes. A series of photographs and maps are included for purposes of illustration.

Trespass on Private Property Prohibited

The well-established rule in all United States jurisdictions is that the public is not allowed to cross private land in an attempt to reach or leave public waters. A Vermont law ostensibly attempting to permit the pubIic to cross uncultivated land in order to reach public fishing waters was declared unconstitutional. Texas courts, like those of other jurisdictions, have ". . - consistently and without exception refused to allow members of the public to trespass on private land to reach navigable waters." [Emphasis added; 136, p. $341 ; 123$, p. 42; 138, p. 10]

In Smith v. Godart [94] it was contended that the legal provision (Art. 4026) declaring all aquatic life in public waters to be the property of the 
state, by implication gives individuals the right to cross private property to catch these publicly-owned fish. This argument was rejected by the court which held:

The Legislature was without power to confer upon any one a right to go upon land owned by another to catch fish in lakes thereon. [94, p. 212]

This rule was further emphasized by the Texas Supreme Court in Diversion Lake Club v. Heath [31], where the court stated:

The right to fish in public water does not carry with it a right to cross or trespass upon privately owned land in order to reaeh the water. [31, p. 445]

In Texas, a section of the Penal Code (Art. 1377b) provides that it is a criminal offense for ". . . any person to enter on the inclosed land of another without his consent and therein catch or take or attempt to catch or take any fish from any lake, tank or stream." [136, p. 341]

It has also been established in Texas that when the state issued original land grants it did not retain an easement by way of necessity across the property to reach other publicly-owned land such as a stream bed. As a general rule of law it is presumed to be understood that a person selling a portion of his land has the legal right of access to the remainder across the part which was sold, if it can be reached in no other way. However, this doctrine is usually not held applicable to sovereigns which have the ability to obtain easements across the property through the power of eminent domain, unlike ordinary citizens. [123, p. 42; 138, p. 10] In State v. Black Bros., the Supreme Court called erroneous and reformed a district court ruling, which had subsequently been overturned by a Court of Civil Appeals desicion, granting a state permitee an easement by way of necessity across private property for the purpose of reaching the publicly-owned river bed to drill for and operate oil and gas wells.

In Chapter III, supra, the significant differences between opportunities 
for establishing public access to coastal beaches and inland waters was contrasted. There it was seen that the common law principles of prescription and dedication which have been relied on to give the public a right of access to beaches has little application to inland waters. Apparently, only in the rarest instances is there likely to be continued public use of long enough duration across a single access point on private land to sustain prescription. It was also noted that streamside property owners are much more resistant than beachfront owners to granting the public a right of access-sothat an implied dedication could be proved.

In a survey of the eastern United States, Countess, et al, reportedly found trespass to be the most serious cause of conflict between landowners and recreationists. [22, p. 149] Without doubt, this finding would find equal or, perhaps, even greater validity in the western states, certainly including Texas. In any event, trespass is recognized as an increasingly serious problem on most of the more popular recreational rivers, though it is generally a matter of less concern on the more spacious margins of lakes.

The loss of privacy suffered by riparian property owners is the major adverse impact of trespass, and the invasion of community and personal privacy is a fear which is frequently expressed by residents in popular recreational areas. It is also recognized that trespass is quite often accompanied by even more serious, but related, problems such as vandalism and littering. Activities such as camping, hunting, nature study (exploration) and picnicking which are often related to water-based recreation can often lead to trespass, especially along streams where public use is particularly heavy. Trespass is noted to be quite prevalent on streams where extended or overnight canoe and float trips are common. [22, p. 149]

Countess, et al, Identify some reasons why the crime of trespass occurs 
so frequently, as follows:

1) Typically, many individuals guilty of trespass are unaware of the infraction. Recreationists often assume that their temporary occupancy along river banks is of no legal or moral consequence. Such ignorance is to some extent a function of insufficient education and inadequate public relations on the part of responsible administrative agencies. 2) Lack of public access also contributes to the incidence of trespass. Popular float streams. . . will continue to be used whether or not support facilities exist for such activities. Clearly, trespassing and its attendant problems will continue to increase on those rivers without adequate management and programming for recreational use. [Numbers added for clarity; 22, p. 149]

There is some reason to doubt whether the-1ret eauge of the growing incldence of trespass (relating to public ignorance and inadequate public information) is especially applicable to the situation in Texas. Almost all residents should be well aware of the fact that Texas is most unlike many other western states in that practically all streamside land is privatelyowned and there is almost no public land. Texas recreationists can only assume that such land is privately-owned unless there is a very clear indication to the contrary. In addition, the Texas Parks and Wildlife Department, as the major state water-based recreation agency, certainly appears to be adequately fulflling its responsibility of disseminating information to the public, as evidenced by these statements from materials available for public distribution on river recreation:

- . the shorelines [of Texas streams] are usually privately-owned and the laws concerning the public's right to use the banks are very ambiguous. Public policy has historically held that if a stream is considered to have a state-owned streambed, a recreationist who steps out of a navigable river onto the bank above the midpoint of the high and low water line (which is often very difficult to identify) may be guilty of trespass. [117, p. 8]

Potential waterway recreationists should be aware that most land along waterways, even those lands adjacent to state-owned stream and river beds, are under private ownership. Caution should be exercised to avoid infringing upon the rights of adjacent landowners and trespassing on private lands. Therefore, waterway recreationists should keep to known public lands, such as city, county, state and national parks, state and national forests, public road rights-of-way and camps privately operated for public use. [55, p. 3] 
Land along public stream beds is most likely privately-owned and the canoeist who steps out onto this land may be guilty of TRESPASS. Therefore, on those waterways where there appears to be any doubt concerning public land ownership, canoeists planning to get out on the banks of the river should obtain permission from landowners before starting their trip. [60, p. 2]

Thus, it would appear that members of the public who take the time to adequately plan for a river trip, or make an effort to find out about the legalities should have ample warning of the potential problems, and should therefore, display extreme care in attempting to leave the stream bed. It should also be remembered that the question of whether or not the public may enter on private land from a public stream in the event of an emergency still has not been settled in Texas.

The lack of points of public access, the second reason mentioned as being a cause of trespass, is very definitely more of a problem confronting recreationists in Texas. Those who plan to camp overnight alongside the stream banks are likely to encounter difficulties, which can best be avoided by limiting the length of time and travel on the river. That is, of course, a function of the availability and spatial distribution of points of public access, a topic to be discussed later. It is suspected that many recreationists put into streams without any notion of how long it will take to complete the journey to the desired point of egress. Reportedly, an average day's recreational trip at a leisurely pace is approximately twelve miles, which must, of course, be adjusted for time consuming activities along the route such as fishing or picnicking. [55, p. 3]

It was also noted, above, that sometimes landowners will give recreationists permission either to reach the public water from their land or egress through their property, or perhaps, use it for other purposes such as camping. Landowners along such heavily used streams as the Guadalupe River would probably not be particularly receptive to such requests. In any event, 
the landowner's permission should be obtained in advance of any attempted use, and recreationists should not depend on the probability of securing needed permission for entry onto private property en route. Public Access Points

Public Parks. In Texas the numerous state, county and city parks and those provided by water resource development and management agencies around reservolrs, provide excellent points of access to public waters. Maps of Texas state parks lndicate that many are ither contiguous to or surround portions of rivers and other navigable waterways. [2, p. 106; 62] Most of the streams which are especially scenic and desirable for recreation have one or more public parks which can provide access to water. Depending on the relative acreage of the park, they can offer access to a considerable expanse of water frontage. Most of the parks located on navigable streams or lakes have boat launching sites, often with improved facilities, and also offer visitors the opportunity to fish from stream banks, from piers, or by wading. Figure 7 illustrates typical access sites found in public parks.

Despite the number of public parks, many feel that there is still insufficient access to meet the public demand and need on some of the more heavily used recreational streams such as those in the Texas Hill Country. Some states have constitutional or statutory provisions guaranteeing the right of access to public waters; but, of course, Texas has no such statutory guarantee. In the situation where there is no clearly defined public right, Davis describes the resultant problems as follows:

- . policy questions arise as to whether and how public access to particular waters is to be obtained for recreational purposes. This is primarily a political question to be resolved in the legislatures. Who will have the power of eminent domain? How and where will it be exercised? [25, p. 231] 
Figure 7. ACCESS SITES IN PUBLIC PARKS

?

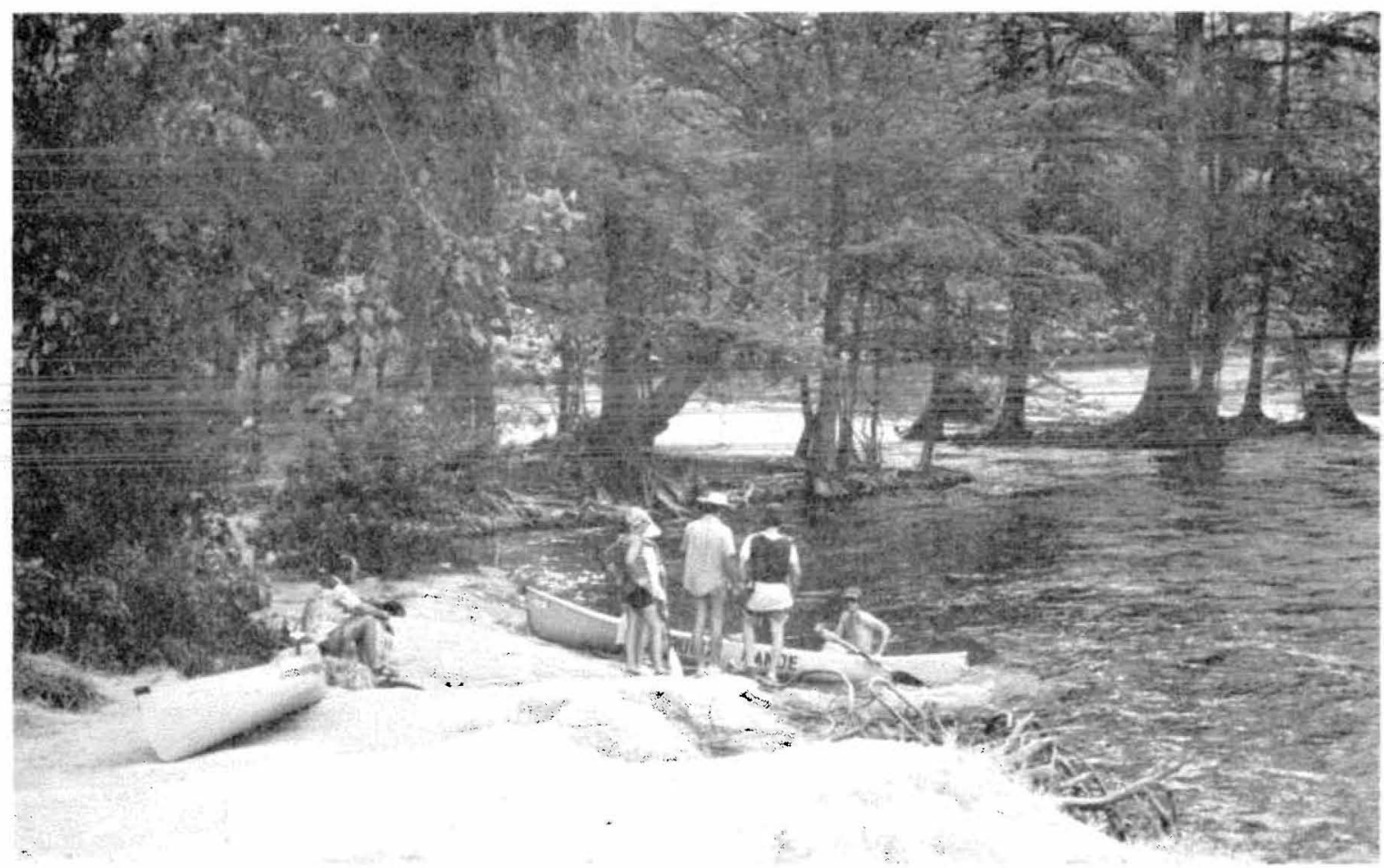

桑

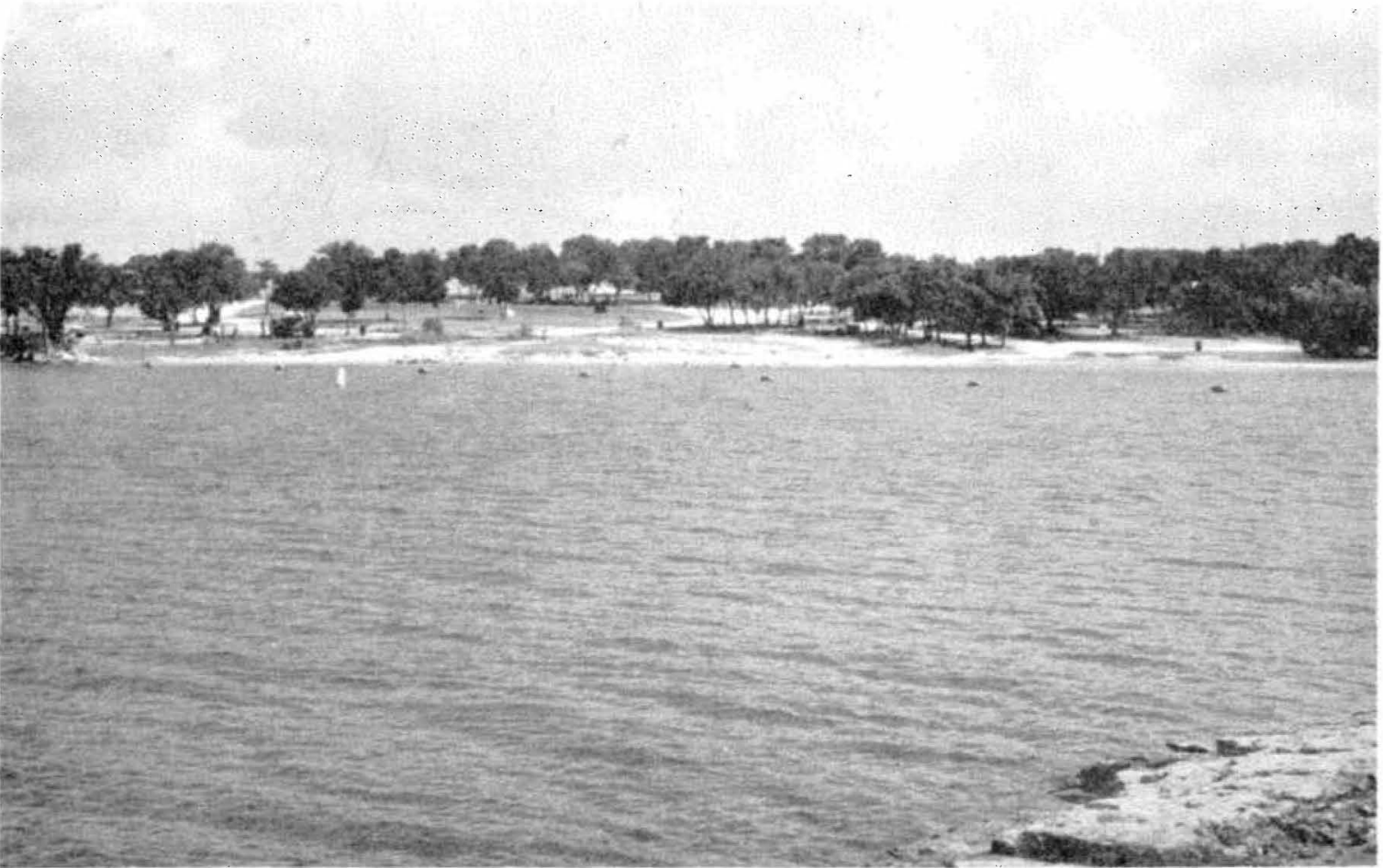


It is also noted that most states have statutes broad enough to support the condemation of public access to water or to public recreational areas and parks; and, the state agency responsible for development of parks and recreational areas often has authority to purchase land and use the power of eminent domain for acquiring public access to water for recreational purposes. [25, p. 231; 102, p. 234] The Texas Parks and Wildlife Department is given such authority in Sect. 21.103 of the Texas Parks and Wildlife Code:

(a) . - the department may acquire park sites, including property already devoted to public use, by purchase, condemnation or other manner - . . (c) The department shall exercise the power of eminent domain in the manner prescribed by the general law . . [116]

Still, there is considerable question about how and when these powers should be utilized.

This fact is illustrated by the example of the Guadalupe River between Canyon Dam and New Braunfels in Comal County. One state official is reported to have said, "If the public demand to use the river is denied the state is going to have to step in." $[45$, p. 76] Various suggestions have been received for improving the number of access sites on the Guadalupe River, and the Department, at the request of the Comal County Commissioners, has developed a plan for egress and ingress points along the river. [45, p. 7]

Recently, a boating trade organization donated $\$ 10,000$ toward the purchase of land for parking and access to the river, but requested matching funds have not been provided by the state. Also, it was reported that Comal County offictals asked the Department to install boat ramps on the river between Canyon Dam and New Braunfels, but the state and county could not agree over who should bear the expense of these improvements. [128g, p. 4] The Department has indicated that the use of state powers of eminent domain to acquire parking and access property have not been seriously considered, and apparently the Department will not become more actively involved in the 
dispute until the local people, including local landowners, seek its assistance, an event which does not seem likely in the near future. [45, p. 7] It would appear that the various facets and factions of this continuing controversy are clearly indicative of the fact that no local or state agency or organization is taking a very active part at this time in trying to resolve this, or similar, situations.

A potential avenue to enlarge the number of points of access to water from public lands stems from the much-debated issue-of-"mitigation." Bast-cally, mitigation requires that terrestrial wildlife habitat be provided to replace that lost by the flooding of federally licensed or constructed reservoir projects. The provision for mitigation is contained in the federal Fish and Wildlife Coordination Act of 1934 , which until quite recently was rarely enforced. A summary of how this highly-controversial issue relates to Texas water projects is contained in a recent issue of Texas Water Resources. [See 75]

Only one extensive mitigation tract has thus far been provided in the state, over 8,000 acres near Pat Mayse Reservoir in northeast Texas under the administration of the Parks and Wildlife Department. The Department does not appear eager to accept a very active role in regard to mitigation:

TPWD makes it clear that its position is somewhat subordinate in the mitigation issue--that is the laws governing mitigation are federal statutes and the only requirement for TPWD involvement is for consultation by the construction agency or permitting agency. The Department has neither the authority to condemn land for mitigation nor the funds to support a large program of intensive management of mitigation lands. [75, p. 4]

Though control of public mitigation lands will normally be offered the Department, which can either accept or refuse the offer, other agencies such as river authorities, cities, or conservation organizations could also assume this responsibility. [75, p. 3] 
Providing for public use is among the purposes for which mitigation lands may be administered. Because most mitigation lands are forested river bottom lands located along both sides or adjacent to streams, it would appear it might be possible for the mitigation land administrator to provide additional public access sites to the river or the reservoir.

Highway Rights-of-Way. Without question, of all the different types of sites where entry can be gained to public water in Texas, highway rights-ofway at stream crossings are the most numerous and accessible. But, there is a great deal of variation in the relative convenience of these access points, and there are seldom any improvements such as boat launching ramps at these crossings. At high bridges, there may or may not be an easy way to get to the river or to park, and sometimes fences on either side of the road rightof-way converge at the bridge. However, it is normally possible to conveniently get to the water at low bridge sites or where low water crossings exist. Figure 8 shows representative examples of such low water crossings. The most convenient access at stream crossings is usually afforded along narrow and relatively unused county roads and farm-to-market roads.

The courts of Texas have always recognized the right of the public to gain access to public waters via highway rights-of-way. In the case of Cornelison v. State [21], the appellant owned land on both sides of a public road which was 30 feet wide, which narrowed to a 14 foot wide bridge at a river crossing. He fenced the narrow span on either side of the bridge to connect his fences, and for this was convicted of "wilfully obstructing a public road." The fence blocked nothing but access to the river. [123, p. 43; 138, p. 10]

Later, in Diversion Lake Club v. Heath [31], it appeared that defendants in error entered Diversion Lake and fished in it by placing their boats into 
Figure 8. PUBLIC ACCESS FROM HIGHWAY RIGHTS-OF-WAY

6.
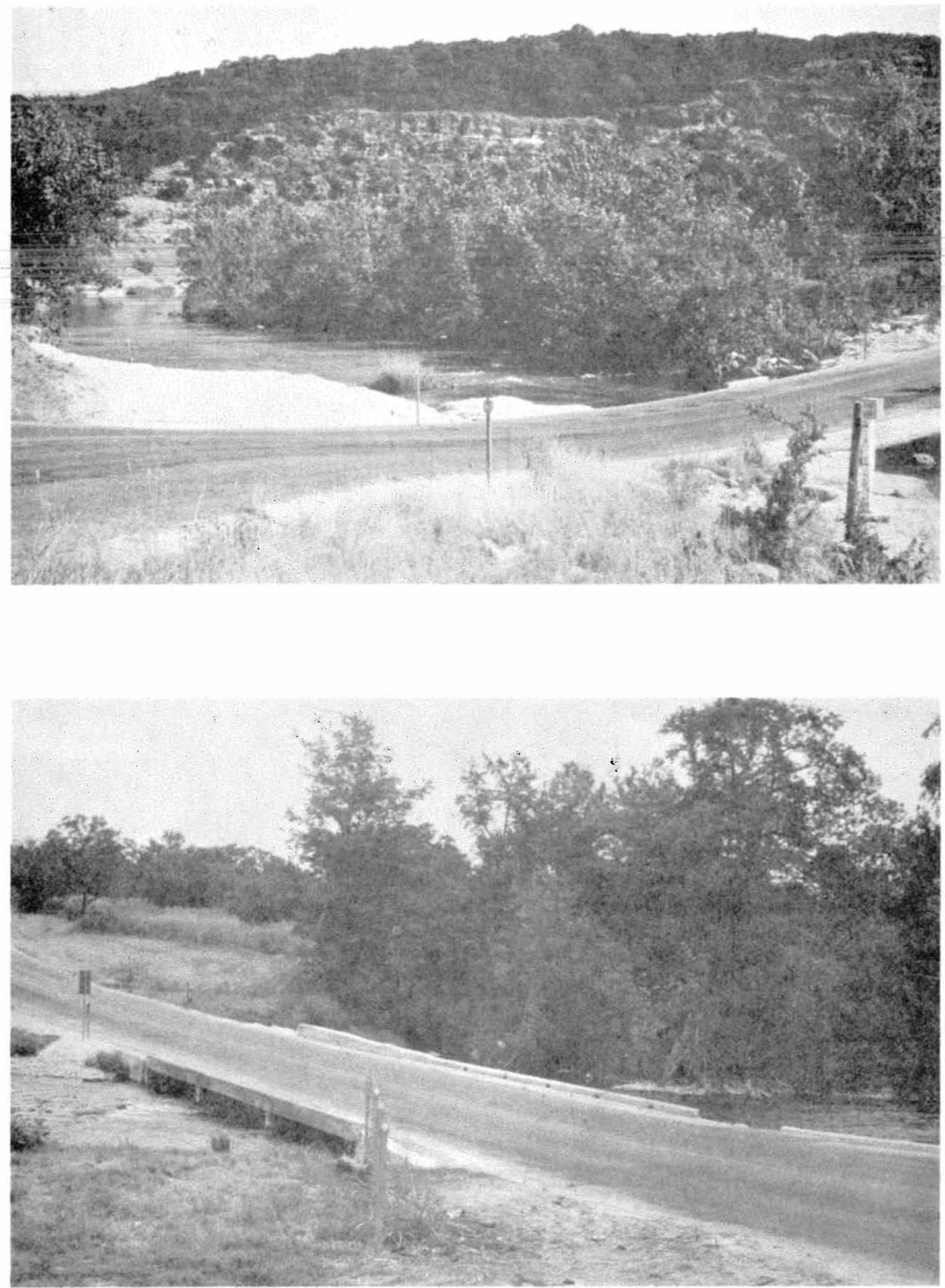
the water from a low bridge on which the public road crossed the river and lake, near its upper end. Thus, they were able to obtain access to the lake without venturing on the property of the plaintiff in error. There the court held:

The trial court correctly enjoined defendants in error from trespassing upon any of the land owned by plaintiff in error surrounding the waters of the lake while permitting them to go upon the lake from the public road which crosses the upper end of the lake on a low bridge. [Emphasis added; 31 , p. 445]

A later Attorney General's opinion supported these authorities, ruling that a riparian owner cannot prevent the public from gaining access to water along highway rights-of-way by erecting a fence to exclude them. [113, p. 5]

On the stretch of the Guadalupe River in Comal County between Canyon Dam and New Braunfels which was discussed in the preceding section, the only public 1and which might allow access to the river is at bridges along the county road right-of-way. However, at each of the bridges crossing the river there are signs posted which warn that boat launching, fishing and parking are prohibited. Henderson describes the problems created in this way:

A group of girl scouts was threatened with arrest if they tried to leave the river across private property. So they tried the county right-ofway at a bridge crossing. A deputy sheriff blocked their way telling them they would be fined for creating a safety hazard. [45, p. 8]

Thus, the obvious concern of prospective river users over the acquisition of parking places and access and launching points along the river road.

While low water crossings and low bridges along rights-of-way do in many instances afford good access points to public waters, at the same time it must be recognized that they can constitute a considerable potential safety hazard to persons canoeing or floating the river. [117, p. 124]

Private Lands Open to the Public. The remaining avenue through which the public may gain access to Texas streams and lakes is through private property which is open to the public. Access through private property can, 
of course, be obtained either by simply asking for and receiving permission from the landowner for a specific use, or by payment of a fee for the opportunity to use the resource. This section considers only the latter.

Landowners may furnish nothing more than a means of access to public waters for such activities as fishing or boating, or, they may provide much more elaborate services. Some of the types of private campground facilitier offered are illustrated by Figure 9. Though there is little data on their number, there are in fact many campgrounds catering to the needs of the public recreationist in Texas. Some campgrounds provide for both day use and overnight use and are complete with running water, restrooms, trailer hookups, picnic tables, etc. Of growing importance in the Hill Country in particular are canoe and float liveries on the more scenic rivers. There the client may rent a canoe or float, and then be delivered to the ingress point and picked up later at the egress point by the livery operator.

Bury observes that, "Since relatively little recreation is supplied by public agencies in the state, private landowners have a great opportunity to develop their resources for recreation." [12, p. 13] However, he recognizes the problems of profitably providing such services in those areas where there are ample free or low-cost public facilities. Though the majority of riparian landowners in an area may be adverse to increased public use of their stream, there is usually someone who, with profit in mind, will provide the service. The existence of such private facilities makes it particularly difficult to accurately assess the real need for increasing the range of public facilities and access to the state's streams and lakes.

Barriers to Public Access and Travel

This section discusses the various sorts of barriers and impediments erected by riparian landowners, such as fences and dams, which the Texas recreationist might reasonably expect to encounter on most streams, but which 
Figure 9. PRIVATE LAND OPEN TO PUBLIC ACCESS

?
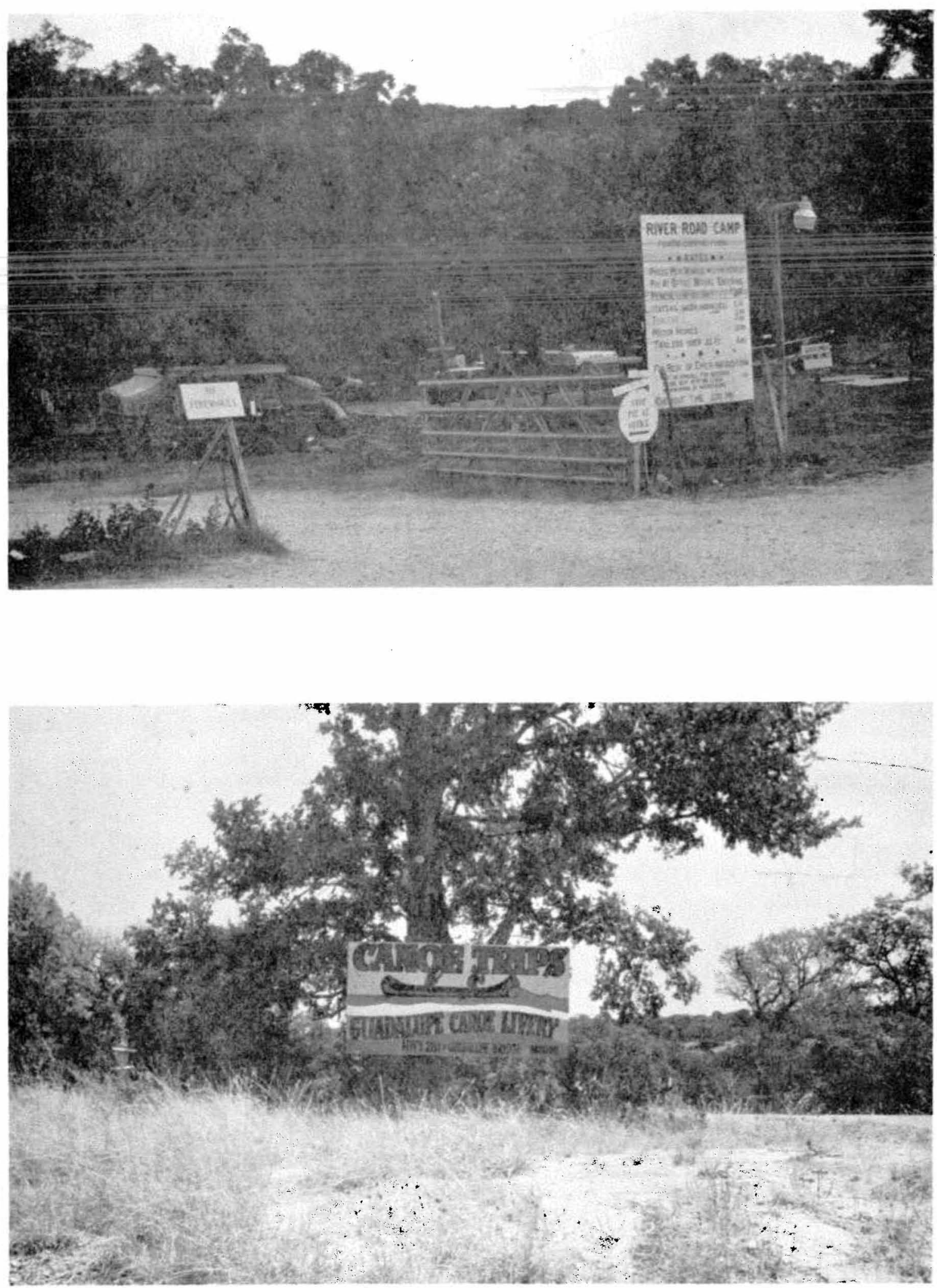
are especially prevalent in the Hill Country. Photographic examples of these impediments are shown in the accompanying figures.

Fences. The problem of fences barring public access to water from road rights-of-way has been previous discussed. [Supra, p. 74] The question of the legallty of maintaining barrier fences across streams has never been directly before Texas courts. However, it would seem to run counter to the public policy statements of the courts. [123, p. 42; 138, p. 9] When asked for an opinion concerning the legality of fences which extended into the water the Texas Attorney General ruled:

The riparian owners. . cannot prevent the public from going up and down the river in boats and fishing in its waters by the erection of fences across the river. [113, p. 5]

In Burr's Ferry, B. \& C. Railway Co. v. Allen [10], the defendant was required to remove toll bridges across the Neches River which unreasonably obstructed the public navigational easement:

Nevertheless, it is a well-established fact that many landowners on small, but legally navigable and public, streams do maintain fences across the waterway. These fences are ostensibly for the purpose of enclosing livestock, dividing properties or sectioning pastures, but they also sometimes serve the function of preventing public passage on the stream. Figure 10 shows such fences, which usually may be crossed only at one's peril. It has been suggested that the only justification for allowing such fences is that the public no longer uses rivers for trade and travel, and that public recreational use does not command a similar protected status, though this would seem contrary to the recognition of public rights discussed in previous sections. [123, p. 42; 138, p. 9]

Dams and Diversion Works. There are many large and small dams and irrigation diversion works which also serve to greatly restrict traffic and 
Figure 10. FENCES OBSTRUCTING PUBLIC ACCESS

2.
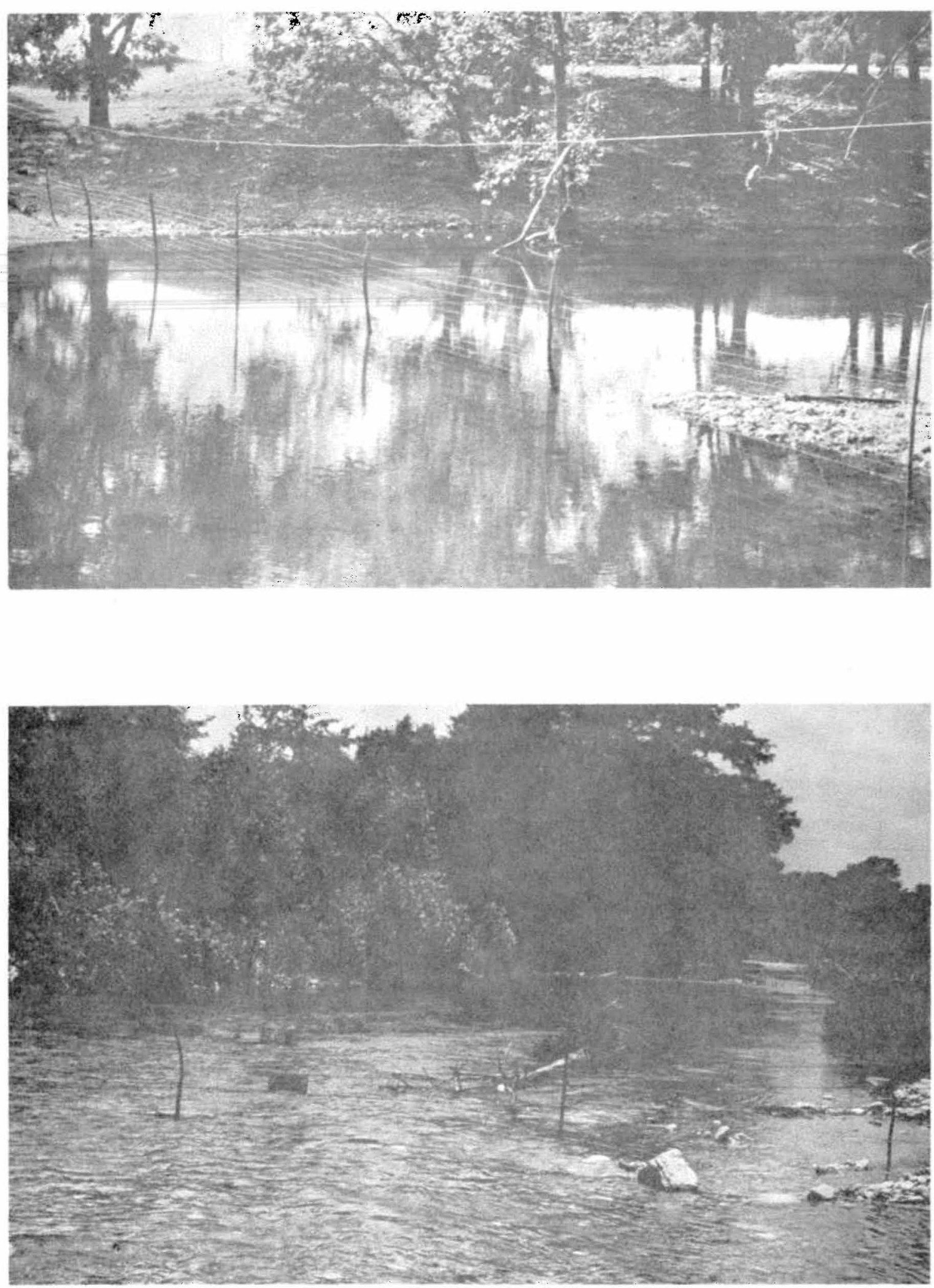
public passage on most Texas streams. The obstruction caused by representative small dams is pictured in Figure 11. Almost all such structures were built under appropriation permits obtained from the Texas Water Rights Commission, and thus they are legal. The rights and duties of these permit holders was addressed by the Texas Supreme Court in Diversion Lake Club v. Heath [31] as follows:

The permit acquired by the irrigation company carried with it the incidental right to construct and maintain the dam and the lake. . . . It gave. . . no right to interfere with the public in thelr use of the rtver and its waters for navigation, fishing, and other lawful purposes further than interference necessarily resulted from the construction and maintenance of the dams and lakes in such manner as reasonabIy to accomplish the purpose of the appropriation. [31, p. 446]

An inevitable result of such impoundments is to change the water line on the original banks of the stream, and perhaps innundate and obscure the gradient boundary dividing public and private ownership. Since the public right of use can be exercised only below this dividing line, the use of the banks is thus largely eliminated. Also, river recreationists forced to detour or portage around legally permitted dams or other obstructions may be subject to prosecution for trespassing on private property.

Most Parks and Wildlife Department publications dealing with recreational waterways list the small dams on the featured streams as among the known danger areas. Several low-water dams on the Guadalupe River below Canyon Dam are noted as obstructions and hazards to recreationists. [117, p. 124] Farther upstream, eight small low-water dams are located on the river between Kerrville and Comfort, which though not restricting streamflow make the river inconducive to recreational use. [117, p. 119] The Blanco River is described as unequaled for the number of small dams in that, "There are 13 in about 25 miles of the winding little stream that is only 87 miles long." [139, p. 29] 
Figure 11. SMALL DAMS OBSTRUCTING PUBLIC ACCESS

중
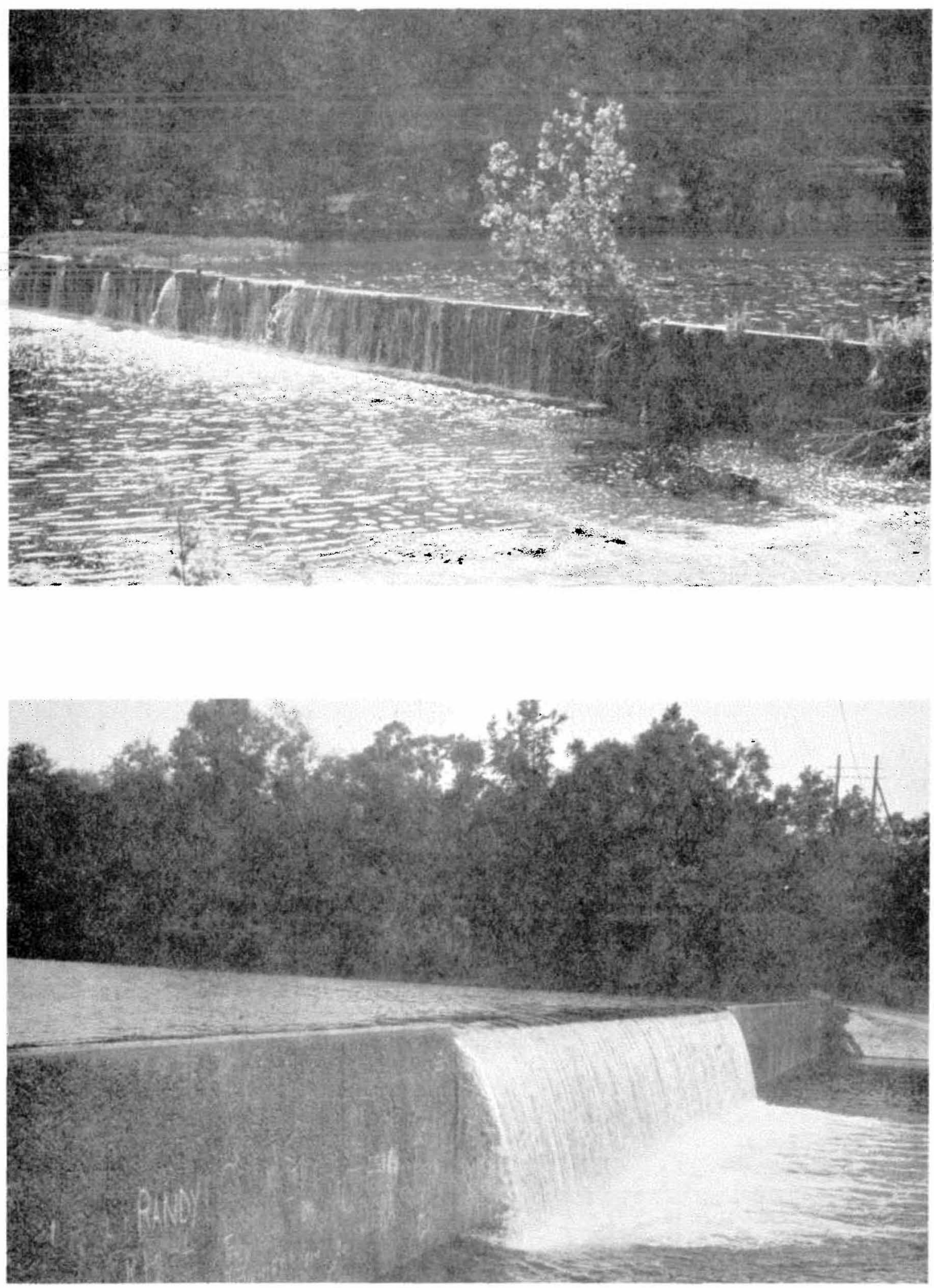
Posted Private Property. It has already been established, as well as being a commonly-known fact, that almost all the land along Texas streams and around some lakes is in private ownership. Thus, the access-seeking public is often confronted with mile-after-mile of fenced and posted private property. The sought-after water can sometimes be seeen, but only from a distance, and the nearest public access point, if one can be found, might be miles away. This situation is vividly portrayed by the pictures in Figure 12. 


\section{CHAPTER V}

SPATIAL ASPECTS OF PUBLIC ACCESS

This chapter examines some of the spatial aspects of public access, basically those which relate to the spacing of access points on streams. It also discusses opportunities for access to lakes, which in Texas are almost all man-made reservoirs. With most lakes the provision for public access appears to be more a function of the type of management system (river authority, Corps of Engineers, etc.) in contrast to streams which are normally not managed by such agencies. This chapter also examines the types of information on access which are available to the prospective recreationist.

Access to Streams

With the recent proliferation of large reservoirs, rivers have become less important to public recreation. "Because [rivers] generally course through private lands, they are looked upon as an exclusive playground, available only to a select few." [130, p. 15] Nevertheless, many outdoor magazines and newspaper columns carry stories about the fishing opportunities offered by such Texas streams as the Guadalupe $[40 ; 140]$, Blanco [139] and Pedernales [38; 141; 142] rivers, to mention only a few, and thus fishermen are attracted to them, as shown by this example:

Just recently I was in Mason, a central Texas farm-ranch community, and decided to run to the nearby Llano River and have a try at bass. I drove about 10 miles west to a place called White's Crossing on a paved farm-to-market road. I parked my car by the bridge and commenced wading upstream, plugging likely spots as I went. I must have traveled more than a mile before turning back and I had my limit of 10 nicesized river bass. [130, P. 16] 
Fishermen are probably generally less concerned over the scenic quality of streams than those demanded by persons interested in canoeing and floating, and the rivers they fish need not flow continuously. In the drier regions of the state and during periods of drought many streams exhibit interrupted flow, having deep holes some distance apart, connected by only a trickle of water or by water flowing beneath the gravel of the stream bed. Aside from articles such as those cited above, there is very little information avallable to the fisherman which is directed to points of public access and fishing areas on rivers. This informational vold would have been considerably alleviated through a series of volumes prepared by the Parks and Wildlife Department entitled, Public Access to Fishing Waters of Texas. In these volumes was included a great deal of information about fishing opportunities and points of public access, accompanied by maps of both streams and lakes, as illustrated by Figure 13. The completeness of the information supplied is shown by this representative sample describing the area shown in the figure:

After originating in southwestern Franklin County, Cypress Creek winds 46 miles into Lake $O^{\prime}$ the Pines. Channel catfish, bullheads and sunfish provide fishing in the upper portion of the creek. As one approaches Lake $O^{\prime}$ the Pines, flathead catfish, crappie and largemouth bass enter the fishing picture. Access is available at five road crossings and no fees are charged for use of the rights-of-way. However, permission must be obtained from landowners before crossing private land.

Site 1. Bank and boat fishing are available. An unimproved launching ramp is located here. No facilities are provided. No fees are charged.

Site 2-5. Bank and boat fishing are available. Boats must be launched by hand at these sites. No facilities are provided. No fees are charged. [121, pp. 7, 10]

Certainly, detailed information and maps of this sort could be extremely useful to the prospective fishing public. For lakes, the publications give still more data with charts of available camping and picnic facilities, 


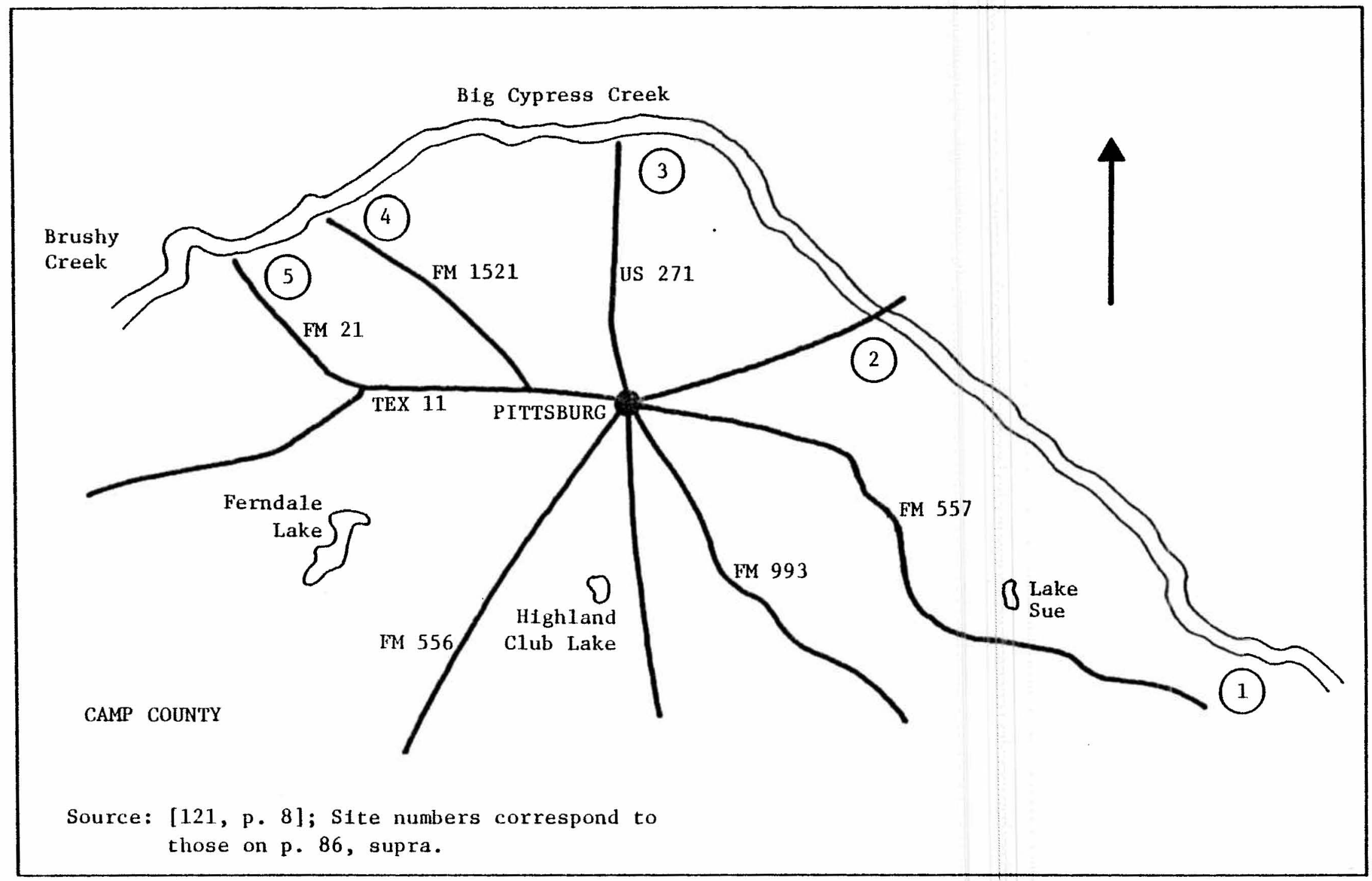

Figure 13. BIG CYPRESS CREEK 
services and supplies, boating facilities and available fishing, in addition to maps showing parks and other public access sites, and verbal descriptions. However, this series was never completed by the Department, only a limited number of copies of the first three (of five) volumes [119; 120;121] were printed, and the publications were never made available for widespread distribution to the public.

With respect to canoeing and floating on Texas waterways, there is a much larger body of readtly avallable material. The need for such information was occasioned by the phenominal increase in interest in canoeing, as explained by land Commissioner Armstrong:

A lot of the trouble we've had on Texas rivers in recent years occurred because people saw [the movie] Deliverance, rented a canoe, and started down the Guadalupe. They didn' $t$ know anything about what gear they should have, how long they'd be on the river, what skill was needed to guide a canoe through rapids, or what their legal rights and duties were. $[3, \mathrm{p} .36]$

In 1969 , 1argely at the urging of Senator Kennard and various environmental groups, the Texas Legislature authorized funding of the Parks and Wildlife Department to make a feasibility study regarding a dual system of trails and waterways within the state. [11, p. 37] The Department adopted the case study method and made a detailed analysis of 22.5 miles of the Guadalupe River immediately above and to the west of Canyon Reservoir. The report was published in 1971 under the title, Pathways and Paddleways. [118] Among the recommendations in the report were the following:

II. The State should designate the study section of the Guadalupe as a scenic river and waterway park and furthermore that:

1. a protective easement, 200-600 feet on either bank, establishing the rights of both private and public interests, be obtained through negotiation with individual landowners.

2. relatively small areas along the more unique bluff formations be acquired by easement or in fee simple for use by the Waterway recreationist. 3. five campgrounds be purchased in fee simple. 4. Edge Falls be purchased in fee simple, and a protective easement be obtalned on both banks of Curry Creek from Edge Falls to 
the Guadalupe River.

5. a protective easement be obtained on the banks of Spring

Branch.

6. a protective easement be obtained on a short section of Honey Creek.

7. legislation be passed giving the Texas Parks and Wildlife Department authority to regulate the number of recreational users of this Waterway in order that the campgrounds and river banks with their native plant and animal life be protected from abuse by uncontrolled numbers of recreationists. [118, p. 9]

The recommendations concerning acquisition of scenic easements along the river aroused unanimous opposition from riparian landowners. Under such easements the landowner can continue many normal productive activities (farming, livestock grazing, hunting, etc.), but cannot erect structures or signs in the easement corridor. Opposition to the proposed legislation was so strong that the bills were not voted out of committee. Also, there was no agreement as to the cost of the easements, estimates ranging from the Department's $\$ 1.3$ million to several hundred million. One state official who favored the legislation observed that such recommendations are "politically and economically unrealistic" at present in Texas. [11, pp. 37-39]

In 1973, another less detailed, but more areally comprehensive, report was released by the Parks and Wildife Department entitled, Texas Waterways: A Feasibility Report on a System of Wild and Scenic and Recreational Waterways in Texas. [123] It proposed the establishment of a state waterway system adapted to the unique conditions of Texas, and used the same criteria as the National Wild and Scenic Rivers Act--wild, scenic, and recreational rivers. The following waterways were identified [123, pp. 20-21] for possible inclusion in the state system:

1) Wild Waterways

Big Sandy and Village Creek

Devil's River

Pecos River
Pedernales River

Rio Grande 
2) Scenic Waterways

$\begin{array}{ll}\text { Angelina River } & \text { Neches River } \\ \text { Big Cypress Bayou } & \text { Nueces River } \\ \text { Blanco River } & \text { Paluxy River } \\ \text { Brazos River } & \text { Pine Island Bayou } \\ \text { Colorado River } & \text { Rio Grande } \\ \text { Frio River } & \text { Sabine River } \\ \text { Guadalupe River } & \text { San Bernard River } \\ \text { Lampasas River } & \text { San Gabriel River } \\ \text { Llano River } & \text { San Marcos River } \\ \text { Medina River } & \text { San Saba River }\end{array}$

3) Recreational Waterways

$\begin{array}{ll}\text { Brazos River } & \text { Leon River } \\ \text { Concho River } & \text { Little River } \\ \text { Guadalupe River } & \text { Trinity River }\end{array}$

Lampasas River

The desirability of establishing such a waterway system is also mentioned in the Texas Outdoor Recreation Plan. [122]

As an appendix to the waterway feasibility report, the Department produced another publication entitled, An Analysis of Texas Waterways, in 1973. The primary purpose of these studies was to enhance the recreational usage of selected rivers and streams in Texas. The analysis concentrates on the physical characteristics of the study streams and among topics analyzed are the identification of floatable waterways, the best times of year to float them, water conditions and flow, general descriptions of the waterways, points of access, outstanding landmarks, unique features and areas which have potential for danger. The designated waterways in both studies are indicated by Figure 14 .

An attempt was made to cover all the rivers, streams, and bayous in Texas that are capable of supporting normal waterway recreational activities such as canoeing, kayaking and rafting. Sections with the greatest 


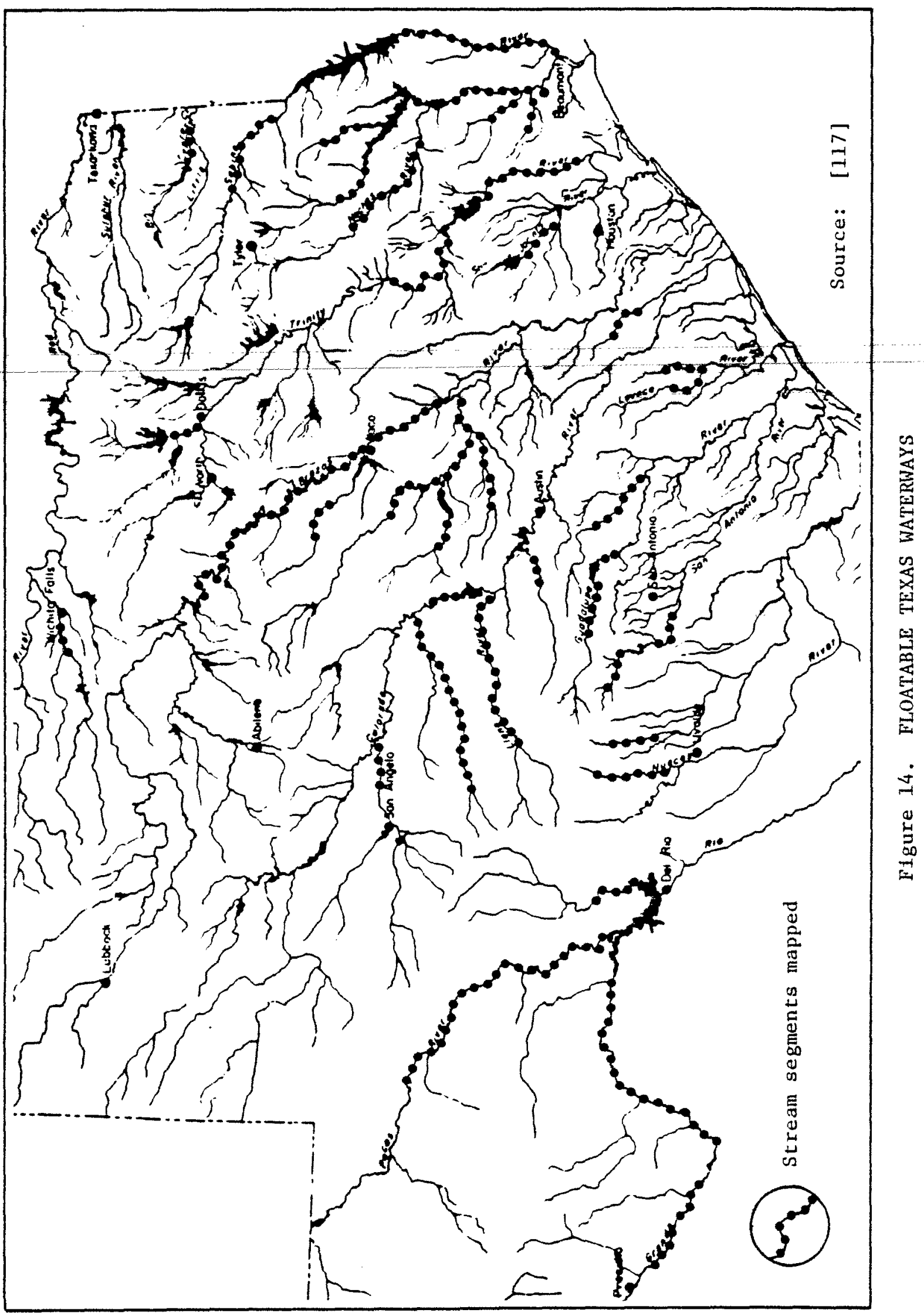


potential were mapped. Secondary waterways which are more restrictive to normal usage because of variation in flow, lack of access, and short length are included in supplemental information. Most waterways are presented in sections of approximately 35 miles in length, a normal two-to-three day float trip. [117, p. 8] In addition to the studies and publications discussed above, the Parks and Wildlife Department has also produced a number of small brochures available for public distribution which deal with the recreational use of Texas waterways. [See $55 ; 56 ; 60$ ]

Unfortunately, none of these studies addresses itself to the legal issues of whether or not the streams identified are publicly-owned and thus open to access. The Analysis of Texas Waterways contains this specific disclaimer :

Information contained within this analysis is not to be construed as to represent a definition of the publicly owned rivers, streams and bayous in Texas. The Texas Parks and Wildlife Department accepts no responsibility, either express or implied, for any legal ramifications occurring from the use of this publication by any person for other than waterway analysis purposes. [117, Cover Page]

and further:

The extensive network of rivers, streams and bayous in Texas have made it impossible to inspect, first hand, all of the sections of waterways covered in this publication. Therefore, no legal assurance can be given that all points of access suggested in this publication are actually open to the public. [117, Foreword]

The most direct approach to a clear designation of navigable public streams is contained in Texas Waterways.... There a letter from the General Land office Commissioner indicated that a limited and cursory search of Texas land titles by personnel of the General Land Office has resulted in a preliminary determination that a series of 1isted streams were probably navigable, and thus open to public access. [Emphasis added; 123, Appendix E] These identified stream segments are indicated in Figure 15. It should be recognized that a more comprehensive determination would require an exhaustive 

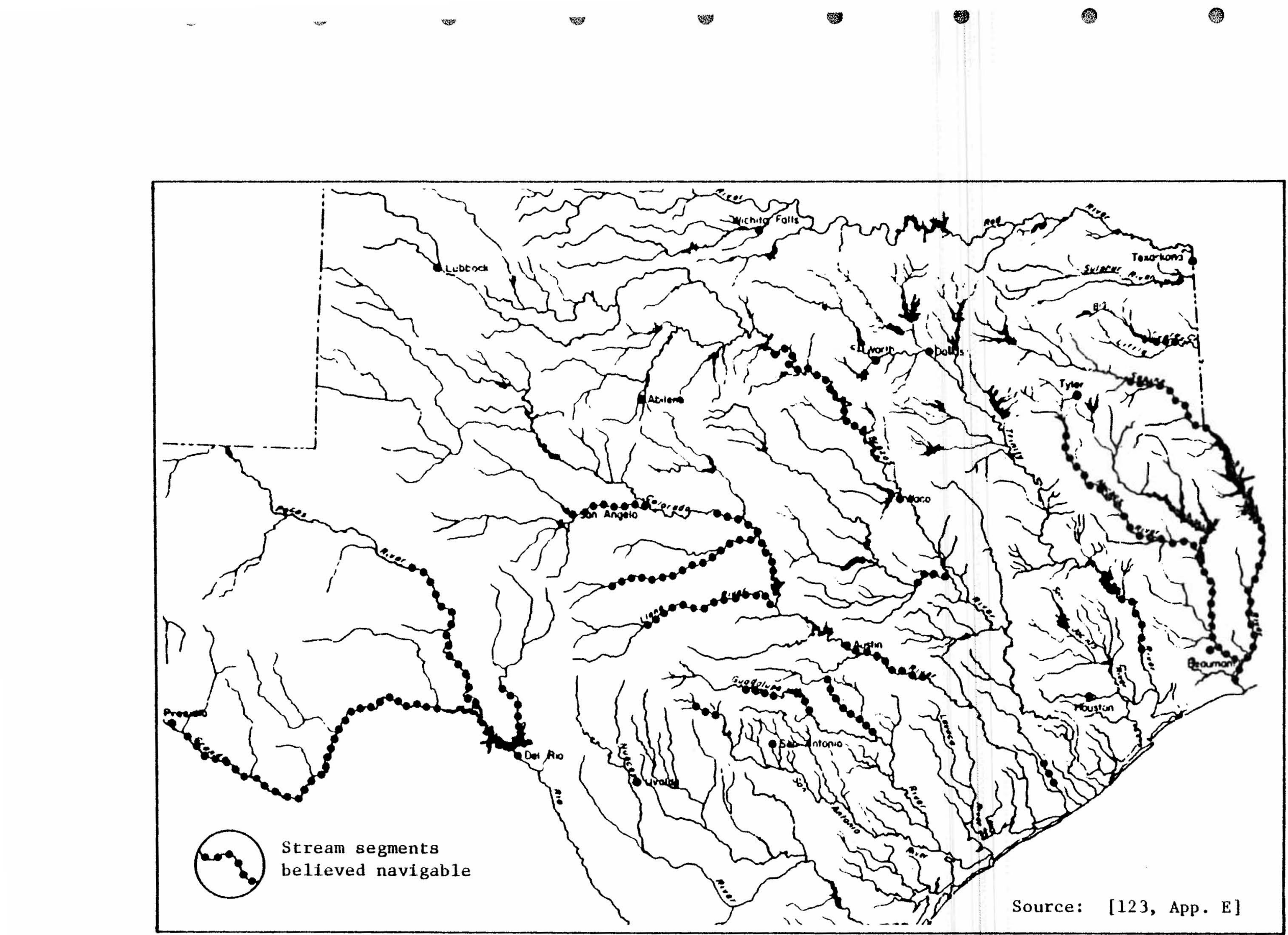

Figure 15. STREAMS BELIEVED OPEN TO PUBLIC ACCESS 
search of titles to all riparian lands in Texas, and even then not all questions about statutory navigability based on average stream width could be answered.

There are several other publications which deal with the recreational use of Texas rivers. Especially recommended for its detailed coverage (both descriptions and maps) is Nolen's Texas Rivers and Rapids. [79, 80; 81] The stream segments described there are indicated by Figure 16. A Camping and Canoeing Guidebook produced by the Sam Houston Area Council of the Boy Scouts of America, also contains detailed information for particular streams, those segments covered being indicated in Figure 17. [13] Little's Camper's Guide to Texas Parks, Lakes and Forests gives excellent coverage of those stream segments in state parks, and also the facilities around major reservoirs. [62] Because of its geographic scope, less comprehensive coverage of floatable Texas streams is found in Maken's Guide to U. S. Canoe Trails. [70] Also useful to the river recreationist are the topographic maps of the U. S. Geological Survey. However, even the largest scale maps do not allow certain determination of width of statutory navigable streams. County maps produced by the Texas Highway Department are particularly helpful in depicting public road crossings along streams. Even most small secondary roads are shown, and are marked to indicate whether they are public or private roadways.

There is a great deal of spatial variation in points of public access to streams in Texas. On some streams the points of access are so far apart as to effectively exclude the majority of the recreation-seeking public, or in other cases the legal status of the stream may be in question. Since, in the event of accident or emergency, recreationists cannot safely enter on private land to leave the stream, few are willing to take the risk of 


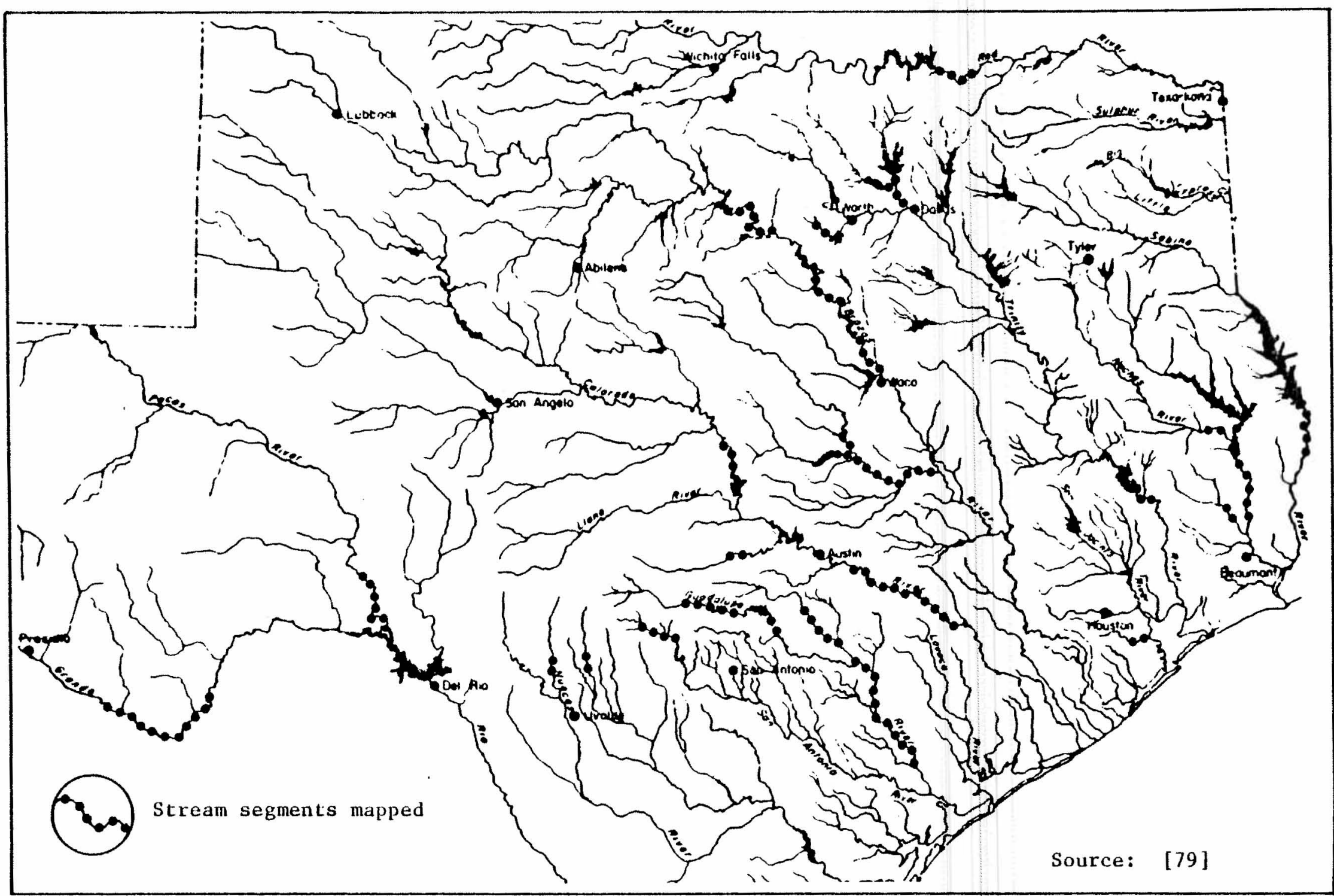

Figure 16. RECREATIONAL STREAMS 


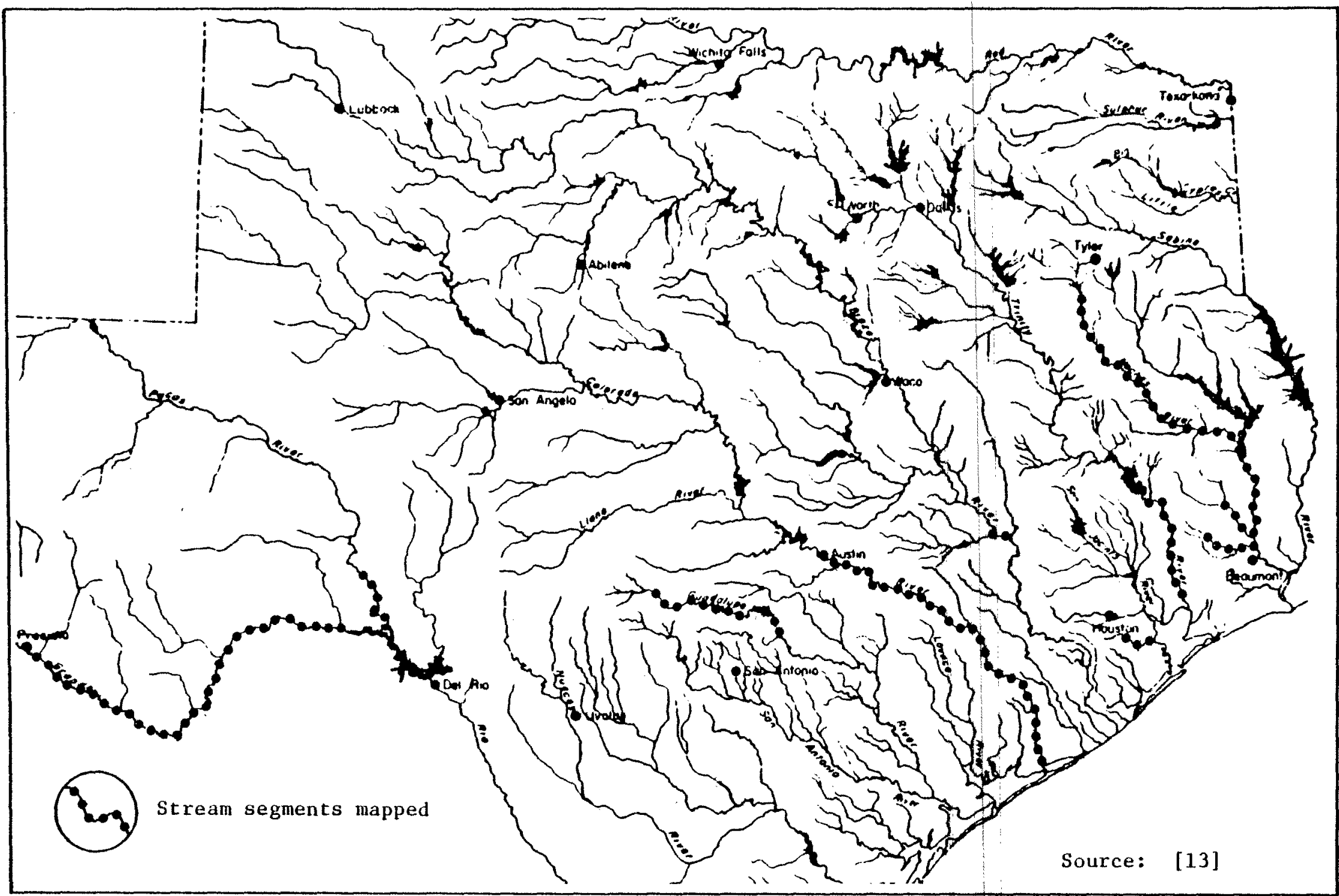

Figure 17. RECREATIONAL STREAMS 
entry. The important distinction between recreational use of rivers and most other water bodies is recognized by Biggs, "[It] offers a peculiar situation - . in that access points are often many miles apart, an unreasonable distance to swim for aid." [5, p. 588]

Variations in the spacing of access points on a stream lend themselves to classification in a very general way, as: 1) easily accessible streams, 2) moderately accessible streams, and 3) streams difficult of access. The examples which follow take into consideration only places where public lands (road crossings or parks) theoretically could provide a point of access. Easily Accessible Streams. Figure 18 illustrates two representative stretches of the Guadalupe River in the Texas Hill Country. In general, the Guadalupe has a number of advantages, in addition to its scenic qualities, which contribute to its enormous popularity: 1) easy access at highway crossings, 2) the possibility of short river trips, and 3) close proximity to major urban areas. The first stretch (A) is located between Canyon Dam and New Braunfels. The marked points of access are where public roads cross the river, but appearances can be deceiving. It must be remembered that these bridge sites are posted with signs warning against parking, boat launching, fishing, etc. [Supra, p. 76] Still, the river is quite accessible because there are numerous places where the public can gain access through commercial campgrounds, etc., for a fee. Farther upstream, on a stretch above Canyon Reservoir (B), there are several highway crossings which are not so distantly spaced as to prevent relatively easy access. Moderately Accessible Streams. Maps of segments of the Llano River (A) and farther west, the Frio and Sabinal rivers (B), are portrayed by Figure 19. This portion of the Llano is marked by an extremely wide bed and the channel often splits into segmented streams. The spacing of access points 
Figure 18. EASILY ACCESSIBLE STREAMS
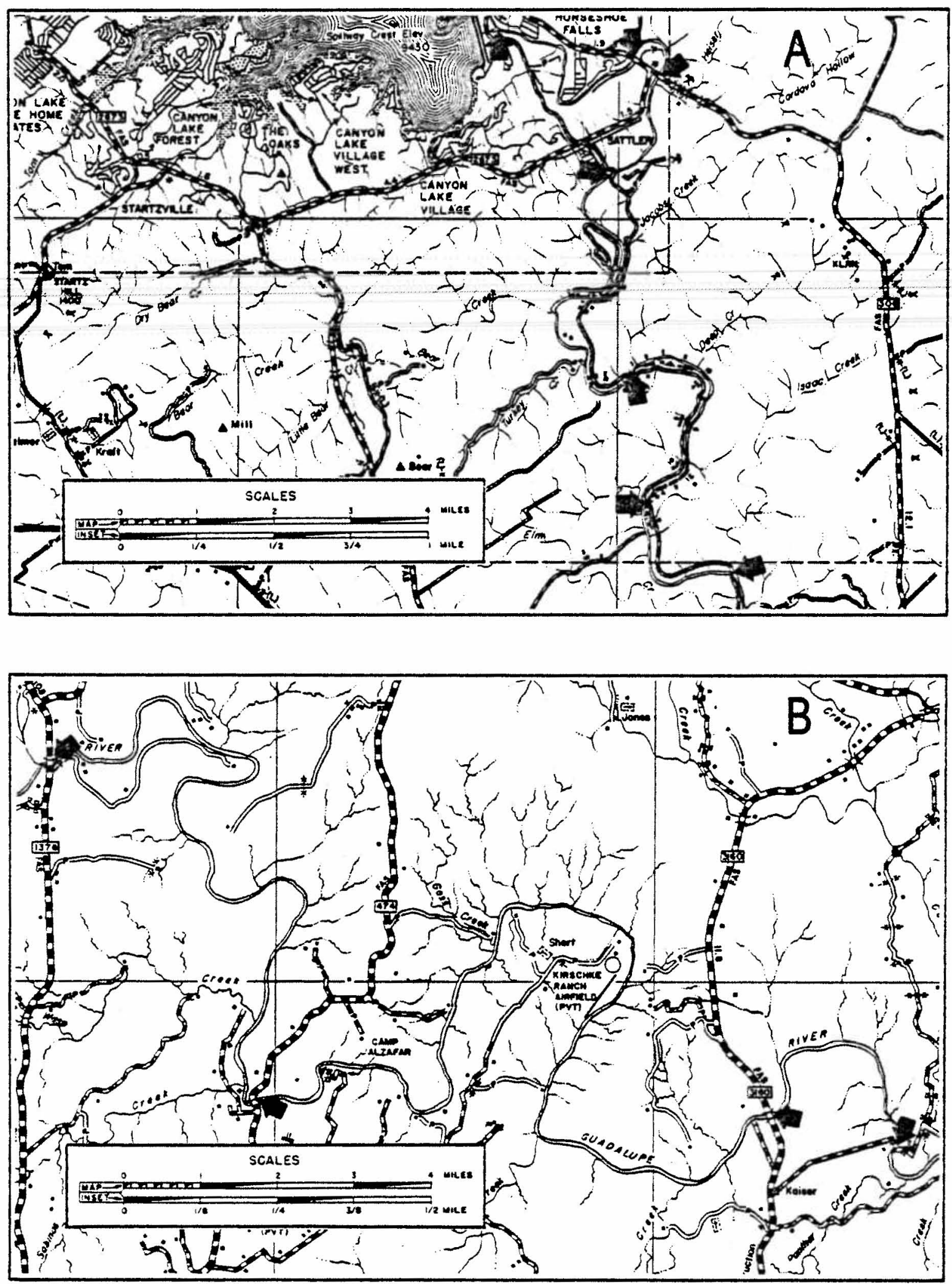
Figure 19. MODERATELY ACCESSIBLE STREAMS
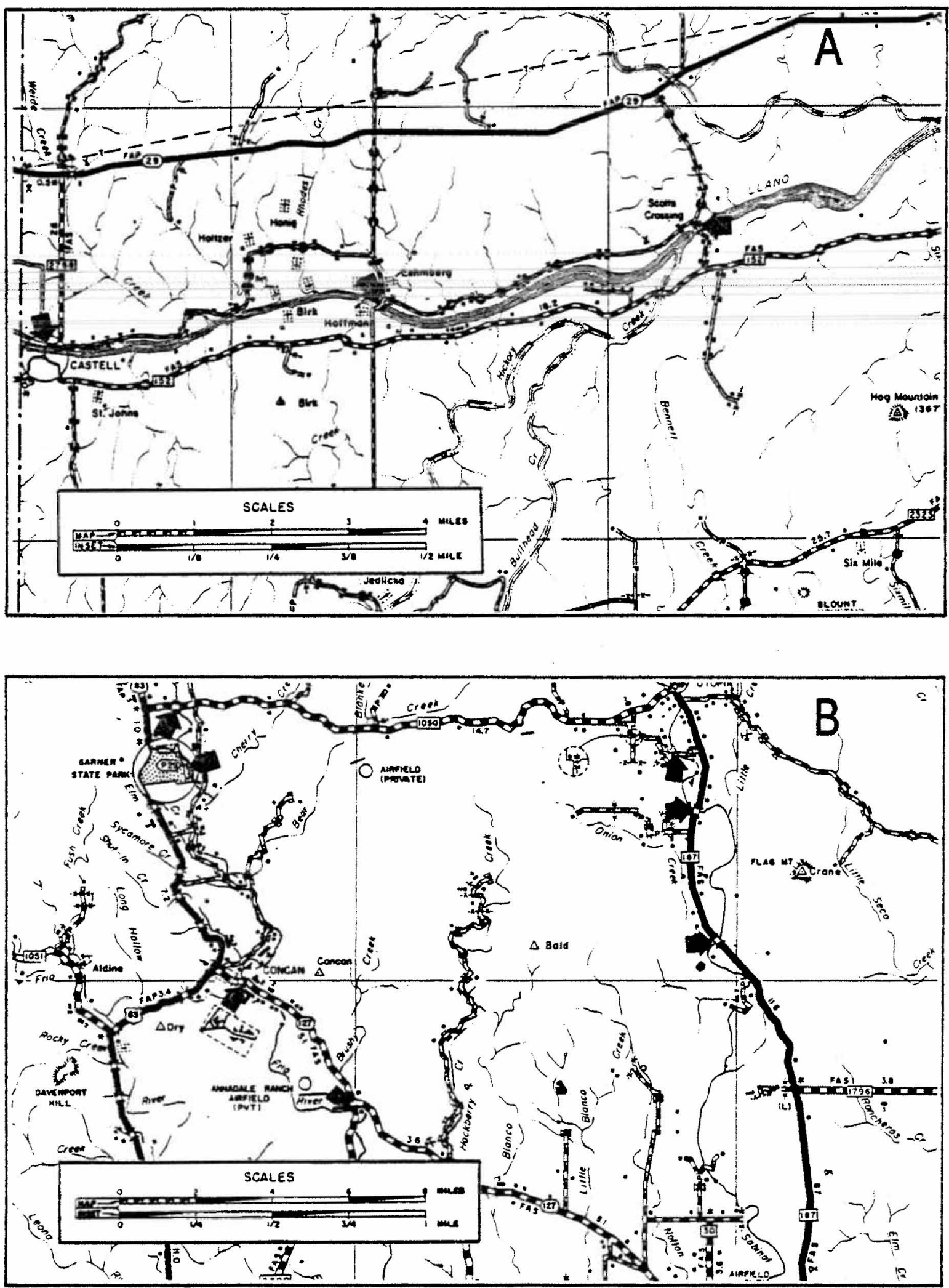
along this stretch is generally more favorable than elsewhere on the river. Like the Llano, the spring-fed Frio and Sabinal rivers are relatively freeflowing streams with no major reservoirs.

These streams might be properly classed as moderately accessible, a category into which most Hill Country streams could be placed. Most of the possible public entry points are from highway rights-of-way and a few parks. However, entry and egress points are generally several miles apart and would generally-require longer-stay on the river than in the case of the Guadalupe. These streams see much less public use, even though they are located relatively near the large urban areas along the southern and eastern margins of the Edwards Plateau.

Streams Difficult of Access. The Devil's River flows southward through a narrow, often canyon-like, valley into international Amistad Reservoir on the Rio Grande. It is considered by many to be one of the finest wilderness waterways in Texas, and its attraction is explained by a river recreationist as follows:

It flows over white limestone for its entire length, and the water varies in color from sky blue to Mediterranean blue. The primary appeal is the topographical contrast; the surrounding countryside is sparsely vegetated, almost stark; yet the river bottoms are scattered with live oaks, cottonwoods, and other large trees. [3, p. 36]

Despite great fluctuations in water level, it could provide opportunities for river recreation. However, as illustrated by Figure 20, there is almost no access to the river with only one point of ingress and egress at each end of a 44-mile stretch between the State Highway 163 low-water bridge crossing and Lake Amistad. Called "virtually inaccessible," the river must be considered difficult of access, and as a result it sees almost no public recreational use. 
Figure 20. ALMOST INACCESSIBLE STREAM

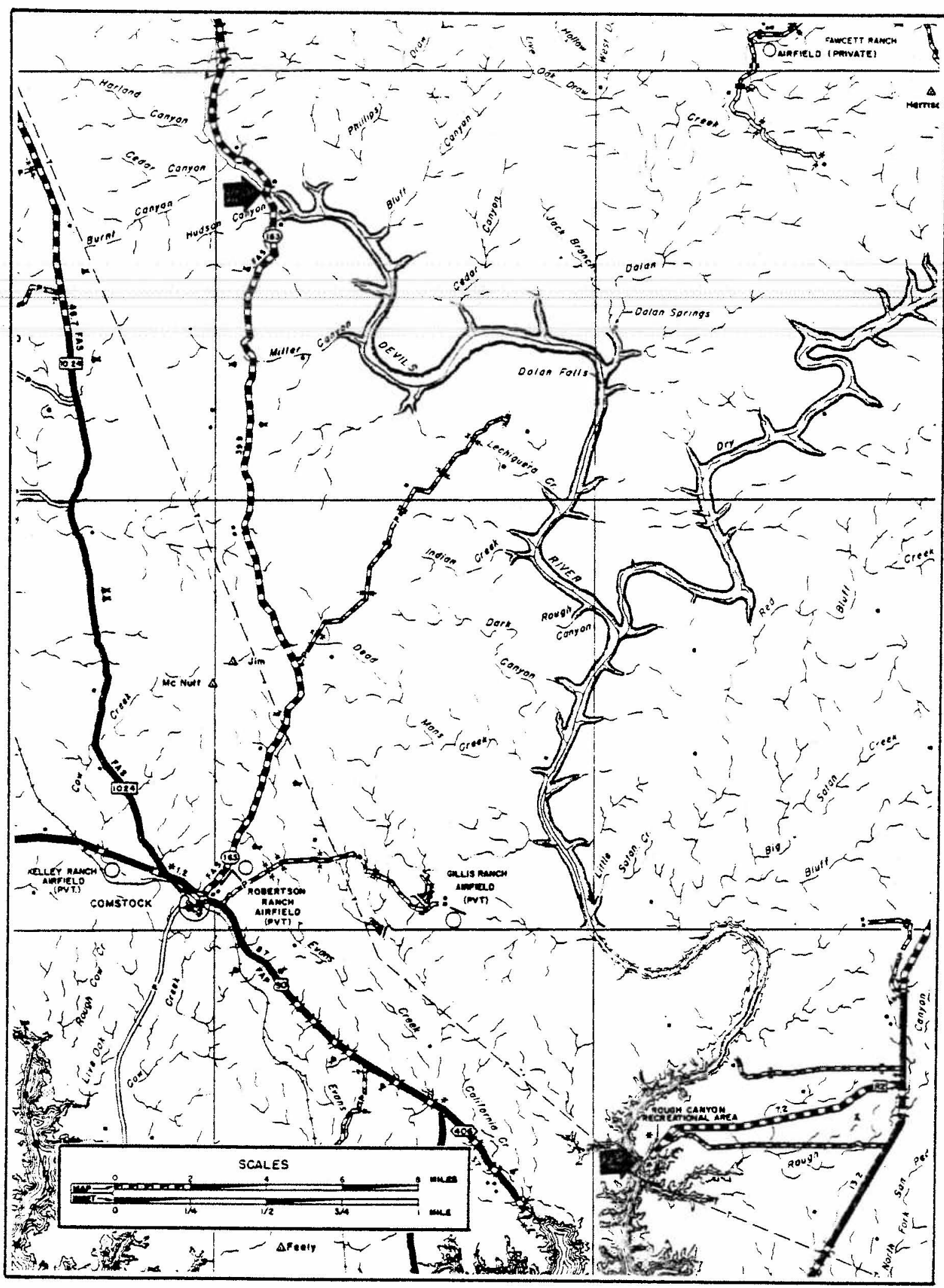


Access to Lakes

As pointed out earlier, opportunities for public access to the numerous man-made lakes is largely a function of the type of agency which constructs and manages the lake. The proliferation of large reservoir construction in recent years has probably significantly decreased the demand for river recreation in most places. In addition, a large number of private lakes and ponds have been built which the Texas Parks and Wildiife Department finds are used by $30 \%$ of all Texas flshermen. [128k, p. 4$]$

Suggitt describes the impact of reservoirs on recreational opportunities as follows:

Reservoirs and recreation are helping to reshape the landscape, people's life styles, and the state's economy. Recreational use is a fortunate by-product of the reservoir's prime purposes such as hydroelectric power or water supply. Most reservoirs are located near areas of greatest population and that compounds the recreational usage. [18, p. 2]

Some Texas lakes have little shoreline development, whereas on other reservoirs it often spreads out for miles, resulting in blighted conditions around some older recreational lakes. Such development is largely unregulated in Texas because it occurs outside incorporated areas, and because the state and counties have little control authority. [104, p. 29; 105, p. 1] A recent study by Johnson, et a1, [52] reveals that Texas is not alone in this respect, only a few states having comprehensive regulation of lake shore development. Among the agencies exerting responsibility for basinwide management of Texas' many intrastate streams are conservation and reclamation districts and river authorities. In the $1960^{\prime}$ s there were found to be more than 600 such authorities and districts in Texas with direct responsibility for some aspect of water development. [67, p. 7] River authorities in particular have varying degrees of statutory responsibility and authority with respect to the provision of park and recreation factlities. [104, p. 30] 
River authorities usually buy flowage easements around their reser$\infty$

voirs, but do not own the lakeshore land. Thus, since all or most of the riparian land is in private ownership, an explosion of real estate development generally occurs, and riparian landowners can erect home, cabins, or docks with little control. Such development can result in "proliferation of ill-defined subdivisions, lack of sanitary sewers, lack of decent roads, lack of public access and just plain urban sprawl," at the same time decreasing the lake's potential for public recreation. $[18, p, 2]$ public facilities for camping, recreation vehicles and boat launching generally are insufficient, these interests having been displaced by private development. The cost of providing recreational facilities is cited as the primary reason for limited public recreational development on river authority reservoirs. The cost of buying peripheral land makes provision of recreational facilities unfeasible. Since most river authorities have no taxing function, increased costs of water or power supplied by the reservoir would have to be passed on to consumers. [18, pp. 2-3]

Suggitt has studied Lake Livingston on the Trinity River in East Texas. He points out the relative lack of public recreational development around the reservoir built to supply water for Houston and contends:

It does not seem reasonable that a public agency should be forced to compete with speculative interests in order to provide for public recreation in cases where it was public investment which caused the land value appreciation in the first place. Had there been a properly prepared comprehensive plan for the entire reservoir region, with an "official map" designating the approximate locations of all planned public lands and rights-of-way, there would be no need for litigation and exorbitant payments for public use lands. [104, pp. 25-26]

Though the Trinity River Authority which manages the reservoir has been authorized to acquire several thousand acres of land for 19 public recreational areas, less than a thousand acres has thus far been acquired. He also notes that the Parks and Wildlife Department, the state agency with responsibility 
for providing public recreation, has made no effort to establish a state park on the reservoir. [104, pp. 24-25]

The relatively limited recreational development around Lake Buchanan on the Colorado River, which is managed by the Lower Colorado River Authority, is illustrated by Figure 21. Nevertheless, river authorities are beginning to assume a greater role in supplying water-based recreation, and the Lower Colorado River Authority is reported to be developing a master plan for the recreational development of some 16,000 acres which it owns along the Lower Colorado and 1ts tributaries. [18, p. 3]

In striking contrast to the largely private development around river authority impoundments are most U. S. Army Corps of Engineers reservoirs. Though recreational uses and values do not rank high among expected benefits in the heirarchy of justifications for Corps projects, more public recreation facilities are generally provided.

Around Corps of Engineers projects, the government owns the land in fee simple all around the reservoir to the water's edge. Access roads and pubIic recreation sites are established by the Corps, which also leases to concessions. The relative lack of private development and the large number and acreage included in recreation sites is illustrated by Canyon Reservoir, a Corps project on the Guadalupe River, in Figure 22. [Also see 124] Recently it has been reported that the Corps of Engineers is becoming increasingly concerned by the "proliferation of private facilities which interfere with the public's use" around its project lakes in Texas [128a, pp. 3-4], and is surveying 17 such lakes looking for "encroachment" by private citizens on federally-owned lakeshore property. [128b, p. 2] 
Figure 21. LAKE BUCHANAN: RIVER ALTHORITY RESERVOIR

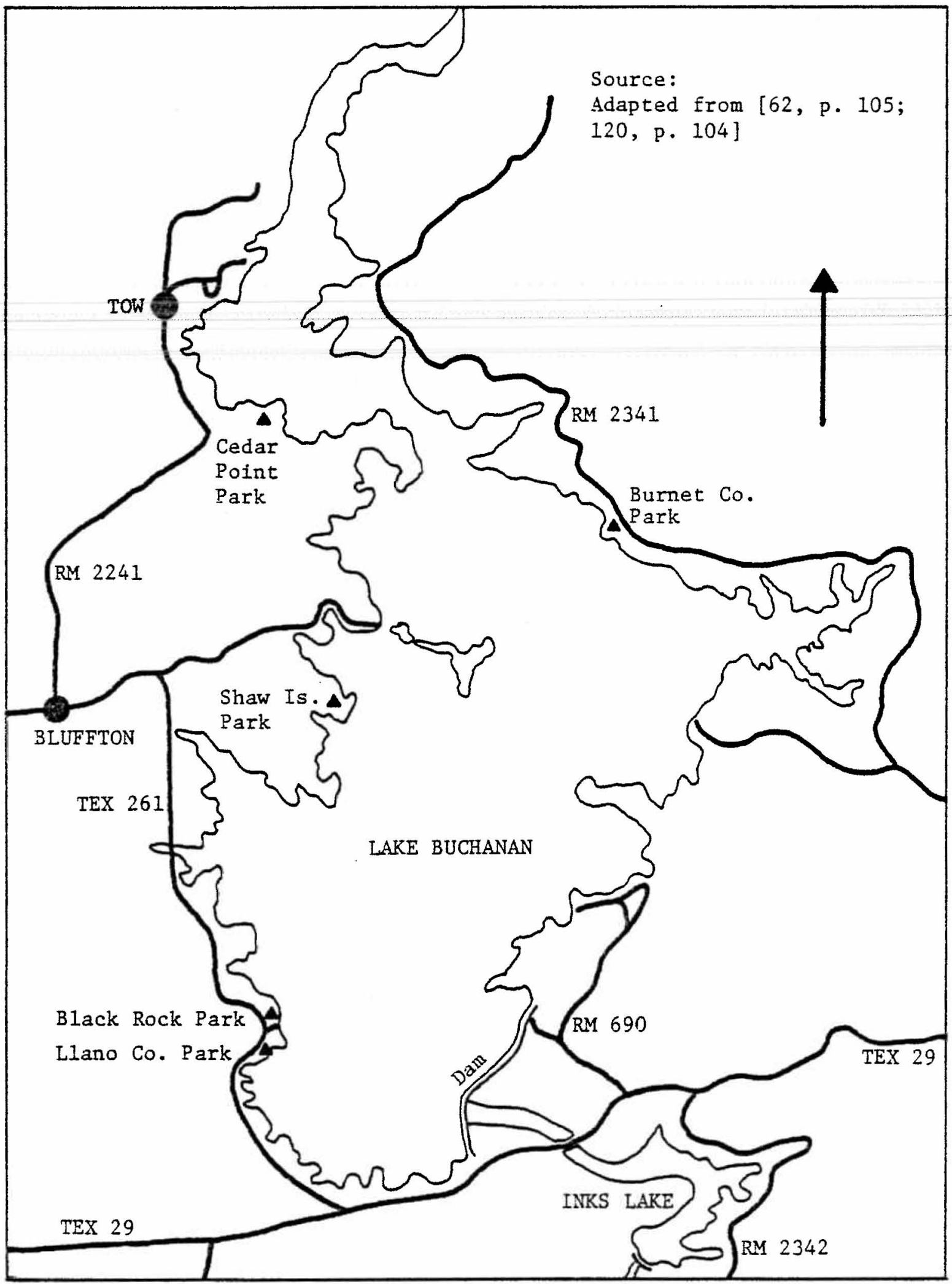




$$
12
$$


CHAPTER VI

SUMMARY AND CONCLUSIONS

Texas has a long and very complex history relating to the development of water law. First, the riparian doctrine was introduced by Hispanic sovereigns, and then continued under the Republic and state into the late 19th century, when the appropriation doctrine was imposed, giving Texas a very complex dual-doctrine legal system. Since the Appropriation Acts of 18891895, the state holds surface waters in trust for the public, though private individuals can acquire rights of use in public waters. Private use for recreational purposes ranks relatively low in the heirarchy of water rights in Texas, and at present there appears to be no adequate mechanism for maintaining minimum streamflow for recreation and wildlife conservation.

Nowhere in the Texas Water Code, which recently codified most water law, is there any specific mention of the public right of access to water. Nevertheless, there are a significant number of cases which do recognize this right for a variety of purposes--navigation and boating, fishing, hunting and camping. Unfortunately, most of the law turns on the peculiar circumstances of each case which makes the establishment of general rules difficult, and also, much of the law is dicta which does not have the same legal validity as a direct holding on the issue by the courts. The right of public access turns on the issue of whether a stream is navigable, and on the question of stream bed ownership. American jurisdictions rejected the English common law notion that only tidewaters were in the public domain, and adopted a test of navigability in fact. In Texas, the situation is even 
more complicated because of the Hispanic ownership of perennial stream beds and the 1837 statute making streams statutorily navigable where their beds average more than thirty feet in width, whether or not they are navigable in fact. This statute greatly expanded state ownership of stream beds in Texas. With the complex mixture of land grants by Hispanic sovereigns, the Republic of Texas and the state, it is understandable that there has been a great deal of controversy over which streams fit the test of navigability and which are thus open to public access. It is impossible for the public to make this determination, nor has it ever been determined by the courts or state agencies, except for short reaches of streams involved in legal controversies. The water rights adjudication, currently in progress, may offer some promise of more extensive determinations of navigability, though this issue has so far only arisen in the adjudication of water rights in one small river sub-basin.

The right of the public to use the banks and shores of navigable waters in Texas is even more tenuous. It has become established by court decision that the line dividing public and private ownership on navigable streams is the gradient boundary on the stream banks. However, the actual demarcation of this line is much more complex and would require extensive surveys. Demarcation has never been attempted for intrastate streams, except experimentally. The method does not produce a line that is easily discernible to riparian landowners or the public. Even if such a line could actually be established, it would be subject to constant change as the stream bed and banks change through the processes of erosion, accretion, etc.

Recognition of public access rights to Gulf of Mexico beaches and tidal waters rests largely on the common law theories of prescription and/or implied dedication, and on the terms of the Open Beaches Act. There is no 
comparable statutory recognition of public access rights to inland waters, and the legal theories applied to coastal beaches do not find equal application to inland waters.

It is most difficult to compare the public access problems of Texas to those of other jurisdictions because of the complexity of the state's Hispanic-Anglo riparian and prior appropriation legal base, and also due to the fact that there is so little public and/or federal land in Texas. A few states have imposed measures such as the establishment of scenic easements along recreational waterways, but this has proved to be a particularly controversial issue in Texas, and the general impracticability of imposing such a system at the present time is generally recognized.

Though they may not cross private lands in doing so, the public can, and often does, gain access to Texas navigable waterways from public lands such as parks, especially in more scenic areas, and probably much more commonly from the more numerous highway rights-of-way crossing streams, despite the fact that these access sites are seldom Improved to aid public use. In addition, private landowners often provide still other entry points, all of which makes it even more difficult to accurately assess the degree to which the public either lacks or needs improved access.

Once access has been obtained to navigable waters, it is not unusual for the recreationist to encounter a myriad of impediments such as private barrier fences across public access points or across the stream itself. Landowners justify such fences as being necessary for livestock containment, but it is recognized that those which exclude the public or block their passage, are illegal. Also, many streams are crossed by numerous large and small dams, most of which have been constructed under state permit. Nevertheless, recreationists forced to detour around barrier fences or dams may 
be subject to trespass charges. Because almost all riparian property in Texas is privately-owned, it is usually posted against trespass.

There are not very many reliable sources where the prospective recreationist can get needed information about his duties and responsibilities as a user of public waters. Published guldes which give information on particular stretches of some streams generally discuss only the physical nature and potential hazards of the waterways, and seldom address themselves to the more complex legal situations that the recreationist is likely to encounter. There is also a great deal of variation on the spacing of posstble access points along streams, which in turn determines how accessible the stream is to the public. Those streams which are difficult to enter because of the lack of access sites see very little public use because of the risks involved. Access to most lakes is thought to be less of a problem. However, the degree to which public recreation sites have been developed around reservoirs is largely a function of the type of management agency, with some lakes having almost no parks and other access sites, whereas others are comparatively well-equipped. Reservoir development in recent years probably has had the effect of lessening the demand for river recreation in most areas of Texas.

It should be clearly evident from the foregoing chapters and the preceding sumary that there are many unresolved problems associated with public recreation on Texas streams and lakes. On Texas streams, the conflicts have become polarized between the recreation-seeking public on the one hand and riparian landowners on the other. The frequency and severity of these conflicts between river user and property owner has been attributed to ". . river location, relative popularity of the site, property ownership distribution (size and number), availability of support facilities, and 
inevitably the personality of the landowner, the river user, or both." [22, p. 149] Bury has identified as another causative factor the traditionally free use of private land in Texas for hunting and fishing. Because there is so little public land, the urbanite seeks recreation where he can find it, and local restdents have regarded such access as a right for years. In the past quarter century, Texas landowners have begun to regard the fish and wildlfe resources on their land and in adjacent waters as salable comodities, and have posted many formerly accessible areas. [12, D. 14]

It 19 easy to apprecfate and sympathize with the vlews of either group. Recently, several very descriptive articles have appeared in the popular press describing the continuing conflict, particularly as it relates to the Guadalupe River, though often from a less-than-objective point of view.

[See $3 ; 6 ; 11 ; 45 ; 90 ; 103$ ] The problems confronted by riparian landowners are described in statements such as these:

Amateurs roamed Texas rivers like lost souls, and for that matter, many were lost. They camped on private property, got shot at by irate farmers and ranchers who became enraged at the piles of rubbish, the cutting of trees for firewood and even the occasional pot shot at cattle or hogs by the rotten apples of the canoeing fraternity. [103, p. 26]

The feelings of the members of the Upper Guadalupe River Association, an organization representing the interests of landowners in preserving the Guadalupe, was sumarized as follows:

The landowners complained of truck loads of litter left by canoeists, cut fences and fishing lines, vandalized storage houses, people carrying guns down the river, diminishing wildlife, and continuing pollution problems caused by the Clty of Kerrville. A significant portion of the people who attempt to canoe down the river on weekends have no idea of how long it may take to reach their destination or where they can legally leave the river without trespassing. As a result, landowners are repeatedly bothered on weekends by stranded canoeists who are miles from their cars, expecting someone to offer assistance. Then on Monday mornings, the landowners are left with the debris left by uninvited campers or careless boaters. [11, p. 38]

In a more general sense, it is noted that though trespassing and littering 
are the major causes of conflict, property destruction and general disrespect for the landowner by recreationists are other common incidents which can have lasting repercussions:

The destruction of one gate or blatant discourtesy to one local resident can promote endless controversy between subsequent users and the landowner. [22, p. 149]

A related area of concern to resource management agencies is the ecological impact of large numbers of public users on the river and its banks. Improved public access can Increase recreational use to the point where the impact is most significant. [30, p. 265] Also, overuse implies unpleasant user experiences as well as degradation of the natural resource. [22, p. 149] Large quantities of water are required to support high-quality recreation experiences for a large number of users. For example, the Wisconsin Outdoor Recreation Plan recommends eight acres per rowboat for fishermen on lakes and larger rivers, twenty acres per power boat, forty acres per water skier, and one-half mile of stream per canoe. [72, p. 745]

Ditton, et al, in a survey of user impact on the Rio Grande in Big Bend National Park, identify access as a major component in explaining adverse environmental impacts. However, they do point out how public access can be manipulated and impacts reduced and redistributed once management goals are established. [30, p. 265]

Despite their adverse impacts on riparian landowners and the creation of problems for resource management agencies, the plight of the recreationseeking public on Texas rivers can also be appreciated. In general, the public often has little idea of where access to rivers can be obtained and there is not a great deal of helpful information on the subject. They perhaps find many obstacles to passage along rivers, and they possibly are subjected to harassment by landowners and local law enforcement officials when 
they do attempt to use public streams. One state official observed:

Local law enforcement people are prejudiced against anybody who looks different or has a different life style. They are not living up to their duty to administer the law fairly; they apply a different standard to people on the river. . . . Until local law enforcement officers are fair to canoeists, many of the conflicts and problems . . . will be insoluble. [11, p. 32]

It has been recognized that, "The root of the problem between landowners and [river recreationists].. . seems to lie in legal ambiguities and uncertainties surrounding the public's right to use navigable streams." [11, p. 39] In recent years, however, legislation which would have helped to alleviate the situation has been unsuccessfully proposed by the Texas Parks and Wildlife Department, General Land Office and by Individual legislators.

In 1969 , a bill was introduced which would have resulted in the creation of a scenic or natural waterways system in Texas. The Senate passed this bill, but it was never reported out of a House committee. The Lesiglature did, however, appropriate funds for the Parks and Wildlife study of the feasibility of establishing a waterway system in Texas, the results of those studies having been discussed in a previous chapter. [Supra, p. 88] The most comprehensive piece of legislation regarding public rights and responsibilities in the use of Texas rivers was introduced in 1973 by Senator Clower. His bill, the Texas Public Rivers Act, would have resulted in the codffication of those segments of Texas water law dealing with the public right of recreational use of inland waters. The proposed act has been thoroughly analyzed by Biggs in a law review article [5], from which this summary is largely derived. Like the Open Beaches Act, it would have affirmed the right of the public to use navigable waterways as follows:

It is hereby declared and affirmed to be the public policy of the State of Texas that the navigable inland waters within this state are reserved for the benefit and use of the public, individually and collec- 
tively; and that the state should guarantee the public's right to use these waters, provide the public the necessary facilities to enable them to use these waters, and provide whatever regulation is necessary for the protection of these waters and the adjacent lands and landowners. [5, p. 582]

Among the provisions of the Texas Public Rivers Act were these important points which directly address several of the recurrent public access and water use problems discussed in this report:

1) It would have prohibited the erection of obstructions, such as fences, etc., which might hinder travel on navigable rivers. An exception was provided for landowners who might find it reasonably necessary to run a fence across it to contain livestock. The Attorney Genera1, or any County, District, or Criminal District Attorney were authorized to seek court orders or injunctions to remove any such obstructions restricting the public right of navigation. [5, p. 583]

2) It would have allowed the reasonable use of riverbanks by recreationists enabling them to detour around obstructions in the river without fear of trespass. However, it did not authorize rest or picnic stops on privately-owned land. [5, pp. 587-88]

3) It would have provided for emergency use of riverbanks so that a recreationist could make reasonable use of the shore during an emergency threatening his life, safety or health without incurring civil or criminal liability. [5, p. 588]

4) It would have authorized the acquisition of private lands for fishing and camping sites along the shores of navigable waterways, and also provided for a General Land Office study to determine the extent and location of public lands along navigable streams. [5, p. 591]

5) Finally, it provided for regulation of public use areas to prevent damage to neighboring landowners, allowing the Parks and Wildlife Department 
to make rules and regulations to govern the administration, operation and use of such areas, including issuance of permits and imposition of fees. $[5$, p. 592]

In addition to recommending adoption of the proposed Act, Biggs also had several suggestions to clarify particular provisions:

1) With respect to the use of riverbanks by recreationists, she felt that there should be a means for determining the location of the legal boundary between public and private ownership, though how this could be accomplished was not specified. [5, p. 588] The problems of surveying, affixing and maintaining such a well-defined boundary were discussed in a previous chapter. [Supra, p. 47]

2) Concerning provision for the emergency use of banks and shores, she recommended setting an arbitrary, unspecified distance from the water's edge for such use. [5, p. 588]

Without doubt, statutory provisions such as those contained in the Texas Public Rivers Act would go a long way toward resolving many of the problems and questions concerning public use of navigable streams in Texas. However, the proposed bill attracted a great deal of opposition from riparian landowners, was not reported out of the Senate Committee on Natural Resources, and thus was never acted upon, leaving Texas among a decided minority of states with no inland recreational waterway legislation. Biggs concluded that:

Until the law is clarified and recreationists and landowners alike are aware of their rights and responsibilities, conflicts and misunderstandings between the two groups can be averted only through individual cooperation. Our present laws, which are a confusing combination of diverse, outdated, and sometimes conflicting laws, need to be clarified by legislative codification. [5, p. 593]

Though such recommendations may be persuasive, political expediency would seem to indicate that Texas is not yet ready for comprehensive, far- 
reaching legislation which would solve many of the more pressing problems of public access in a single stroke.

Even less comprehensive measures directed toward more specific quesgions such as determination of navigability, are similarly unattainable in most instances. It has been shown that reference to the largest scale maps commonly available to river recreationists does not allow an adequate determination of navigability based on the statutory definition of stream width. Surveying streams to determine navigabllity and to establish and demarcate the gradient boundary separating public and private ownership would also be prohibitively time-consuming and costly, and the effect water rights adjudication may have in settling these issues is as yet unknown. Nevertheless, it would be useful for the General Land office to expand on the preliminary determination of navigability made in 1973 , with a more thorough search of riparian land titles. Even a semi-official determination of state-owned riparian lands would be useful, and a map showing stream segments thought to be publicly-owned would be most helpful to recreationists.

Certainly, the most attainable goal at present lies in the general area of dissemination of more reliable information on public access, or more effective public education. Agencies concerned with water-based recreation should make every effort to furnish the public with information about streams, access points, etc. This was accomplished to some extent by the Parks and Wildife Department studies discussed in the previous chapter, and also by the commercial recreation guides, though they are all chiefly directed to canoeing. Other lawful uses should also be considered, and more comprehensive and continually updated coverage of the type contained in the abortive series on public access to the fishing waters of Texas could fill an information void. The Parks and Wildlife Department appears to be in the 
untenable position of: 1) Attempting to insure that the navigable inland waters of Texas remain open to public use, and 2) Fearing the impact of increased waterway use on both the natural resources the agency is attempting to conserve and the user experience. After actively, and largely unsuccussfully, trying to improve public access during the first part of this decade the agency has apparently now adopted a more cautious stance. Many other unresolved problems, far beyond the scope of this research, would benefit from further investigation, among them such issues as: 1 ) case studies to more accurately measure the public demand and need for improved access; and 2) the extent to which reservoir development and private land open to the public may have reduced the demand for improved access; and 3) the study of conflicts arising from incompatible public uses (canoeing, fishing, etc.), and the possible need for regulation.

It must be concluded that the measures discussed above, tentative as they are, represent the only steps short of comprehensive legislation, which might help resolve the issue. Thus, conflicts between riparian property owners and the recreation-seeking public (and possibly between members of the public) will probably continue to increase in number and in rancor; and the unresolved legal questions which are the basic underlying causes must still be answered by the courts in an aimless, piece-meal fashion. 


\section{REFERENCES}

1. Anderson, Dorothy H., et al, (comps.). An Annotated Bibliography on River Recreation. St. Paul, Minn.: USDA, Forest Service, North Central Forest Experiment Station, 1978.

2. Arbingast, Stanley A., et a1. Atlas of Texas. Austin: University of Texas, Bureau of Business Research, 1976, 5th edition.

3. Armstrong, Bob. "Rapld Transit," Texas Monthiy, III, 1子o, 4 (AprII, 1975), 36 .

4. "Beds, Banks and Shores," Texas Jurisprudence 2d, Vo1. LX. San Francisco: Bancroft-Whitney, Inc., 1964, pp. 576-85.

5. Biggs, Susan B. "Recreational Use of Texas Rivers - Recommendations for Adoption of the Texas Public Rivers Act," St. Mary's Law Journal, VII, No. 3 (1975), pp. 575-93.

6. Boyd, Bob. "Guns Along the Guadalupe," The Texas Observer, LXV, No. 18 (September 21, 1973), 9-10.

7. Brower, David J., et al. Access to the Nation's Beaches: Legal and Planning Perspectives. Raleigh: North Carolina State University, Sea Grant College Program, February, 1978.

8. Brown v. Linkenhoger, 175 SW2d 975, Tex Civ App (1943), Err. ref., w.o.m.

9. Burka, Paul. Public Right, Public Interest and Public Trust: Three Means to One End. Austin: Texas Coastal and Marine Council, 1974.

10. Burr's Ferry, B. \& C. Railway Co. v. Allen, 164 SW 878, Tex Civ App (1914), Err. ref.

11. Burton, Amon. "On the Waterfront," Texas Monthly, III, No. 4 (April, 1975), 32-34+.

12. Bury, Richard L. "A General View of Institutional Constraints as Factors in the Development of Recreation Resources in Texas," in Research on Texas Water and Recreational Resources. Departmental Information Report No. 7. College Station: Texas A \& M University, Department of Agricultural Economics and Sociology, 1968, pp. 11-18.

13. Camping and Canoeing Guidebook. Houston: Sam Houston Area Council, Boy Scouts of America, 1972 . 
14. "Canyon Lake Map," The Texas Fisherman, II, No. 5 (September, 1974), $20-21$.

15. City of Austin v. Hall 93 Tex 591, 57 SW 563, Tex Sup Ct (1900).

16. City of Victoria v. Schott, 29 SW 681, Tex Civ App (1895).

17. Clark, Charles E. "Limitation Title--Adverse Possession--Riparian Rights to River Beds," Texas Law Review, XXVI, No. 2 (December, 1947), 223-25.

18. "Come on In . . . The Water's Fine," Texas Water Resources, II, No. 3 (April, 1976), 1-4.

19. Corker, Charles E. "Thou Shalt Not Fill Public Waters Without Public Permission--Washington's Lake Chelan Decision," Washington Law Review, XLV, No. 1 (March, 1970), 65-93.

20. "Where Does the Beach Begin, and to What Extent is This a Federal Question," Washington Law Review, XLII, No. I (October, 1966), 33-118.

21. Cornelison v. State, 49 SW 384, Tex Civ App (1899).

22. Countess, Michael L., et al. "Problems and Conflicts Associated with River Recreation Programming and Management in the East," in River Recreation Management and Research. General Technical Report NC-28. St. Paul, Minn.: USDA, Forest Service, North Central Forest Experiment Station, 1977, pp. 147-50.

23. Cranda11, Tom. "Shoreline Development Controls and Public Access to the Ocean's Edge," Coastal Zone Management Journal, I, No. 4 (1974), 365-94.

24. Curtis, Eric J. "Some Legal Aspects of River Recreation Management in the East," in River Recreation Management and Research. General Technical Report NC-28. St. Paul, Minn.: USDA, Forest Service, North Central Forest Experiment Station, 1977, pp. 8-18.

25. Davis, Clifford. "Water Policy and Planning in the East," Chap. 33 in Robert E. Clark (ed.), Waters and Water Rights, Vol. 7. Indianapolis: The Allen Smith Company, 1976, pp. 219-48.

26. Dewsnup, Richard L. Public Access Rights in Waters and Shorelands. Legal Study No. 8-B. Arlington, Va.: National Water Commission, September, 1971 .

27. Dincans v. Keeran, 192 SW 603, Tex Civ App (1917).

28. Ditton, Robert B. Water-Based Recreation; Access, Water Quality and Incompatible Use Considerations: An Interdisciplinary Bibliography. Exchange Bibliography No. 193. Monticello, I11.: Council of Planning Librarians, 197 . 
29. - Water-Based Recreation: Supply and Demand Considerations. Exchange Bibliography No. 159. Montice110, I11.: Council of Planning Librarians, 1970.

30. et al. "A Survey and Analysis of Recreational and Livestock Impact on the Riparian Zone of the Rio Grande in Big Bend National Park," in River Recreation Management and Research. General Technical Report NC-28. St. Paul, Minn.: USDA, Forest Service, North Central Forest Experiment Station, 1977, pp. 256-66.

31. Diversion Lake Club V. Heath, 126 Tex 129, 86 SW2d 441, Tex Sup Ct (1935).

32. Dobkins, Betty Eakle. The Spanish Element in Texas Water Law. Austin: University of Texas Press, 1959.

33. Driver, B. L. and John R. Bassett. "Defining Confliets Among River Users: A Case Study of Michigan's Au Sable River," Naturalist, XXVI, No, 1 (Spring, 1975), 19-23.

34. Dutton v. Vierling, $152 \mathrm{SW}$ 450, Tex Civ App (1912).

35. Ellis, Willis H. "Watercourses--Recreational Uses for Water Under Prior Appropriation Law," Natural Resources Journal, VI, No. 2 (April, 1966), $181-85$.

36. Evans, Alvin E. "Riparian Rights in Artifictal Lakes and Streams," Missouri Law Review, XVI, No. 2 (Apri1, 1951), 93-117.

37. Fisher v. Barber, 21 Sw2d 569, Tex Civ App (1929).

38. Goodspeed, John. "Pedernales Falls--Paradise Found," San Antonio Express-News, (August 28, 1977), P. 6-H.

39. Graves, John. Goodbye to a River, A Narrative. New York: Knopf, 1960.

40. "Guadalupe River Trout Fishery," Texas Parks and Wildlife, XxxV, No. 6 (June, 1977), 23-24.

41. Haddaway, Arthur S. "Waters and Watercourses--Title to Bed of Streams," Texas Law Review, VI, No. 4 (June, 1928), 524-27.

42. Hawkins, Wallace. "Title to River Beds in Texas and Their Boundaries," Texas Law Review, VII, No. 4 (June, 1929), 493-519.

43. Heard v. Town of Refugio, 129 Tex 439, 103 SW2d 728, Tex Sup Ct (1937).

44. Heikoff, Joseph M. Shorelines and Beaches in Coastal Management: A Bibliography. Exchange Bibliography No. 876. Monticello, Il1.: Council of Planning Librarians, 1975.

45. Henderson, Jim. "Environment: Bullets, Buckshot and Barbed Wire," Southern Outdoors, XXVI, No. 5 (August, 1978), 6-8+. 
46. Hutchins, Wells A. Texas Law of Water Rights. Austin: Texas Board of Water Engineers, 1961.

47. Water Rights Laws in the Nineteen Western States, Vol. I. USDA, Economic Research Service, Natural Resource Economics Division, Miscellaneous Publication No. 1206. Washington, D.C.: U.S. Gov't Printing office, 1971.

48. Jacobstein, J. Myron and Roy M. Mersky. Water Law Bibliography, 18471965. Silver Spring, Md.: Jefferson Law Book Co., 1966.

49. Water Law Bibliography, 1847-1965, Supplement 1, 1966-67. Silver Spring, Md.: Jefferson Law Book Co., 1969.

50. Water baw Bibliography, 1847-1965, Supplement 2, 19681973. Silver Spring, Md.: Jefferson Law Book Co., 1974.

51. Johnson, Corwin W. "Legal Assurances of Adequate Flows of Fresh Water into Texas Bays and Estuaries to Maintain Proper Salinity Levels," Houston Law Review, X, No. 3 (March, 1973), 598-640.

52. , et al. Legal Aspects of Land Use Regulation of Lake Shorelands by State and Local Governments for the Protection of Lakes. Technical Report CRWR-142. Austin: University of Texas, Center for Research in Water Resources, 1976.

53. Johnson, Ralph W. and Russell A. Austin, Jr. "Recreational Rights and Titles to Beds on Western Lakes and Streams," Natural Resources Journal, VII, No. 1 (January, 1967), 1-52.

54. Jordan, Terry G. "Antecedents of the Long Lot in Texas," Association of American Geographers, Annals, LXIV, No. 1 (March, 1974), 70-86.

55. Josselet, Ron and Bob Evans. Floating Texas Waterways. PWD Leaflet 9000-39. Austin: Texas Parks and Wildlife Department, December, 1977.

56. The Waterways of Texas. PWD Leaflet 9000-38. Austin: Texas Parks and Wildlife Department, December 1977.

57. Kiechel, Walter, Jr., and Martin Green. "Riparian Rights Revisited: The Legal Basis for Federal Instream Flow Rights," Natural Resources Journal, XVI, No. 4 (October, 1976), 969-74.

58. "Landowner Told He Can't Fence Underwater Land," San Antonio ExpressNews, (August, 1977), p. 5-G.

59. Lee v. Grupe, 223 Sw2d 548, Tex Civ App (1949).

60. Leifeste, Tim. Canoeing Basics. Austin: Texas Parks and Wildlife Department, n.d.

61. Lime, David W. "Back Country River Recreation: Problems and Research Opportunities," Naturalist, XXVI, No. 1 (Spring, 1975), 2-6. 
62. Litt1e, Mildred. Camper's Guide to Texas Parks, Lakes and Forests. Houston: Gulf Publishing Co., 1978.

63. McCurdy v. Morgan, 265 Sw2d 269, Tex Civ App (1954).

64. McKnight, Joseph $W$. "The Spanish Watercourses of Texas," in Essays in Legal History in Honor of Felix Frankfurter. New York: The BobbsMerrill Co., Inc., 1966, pp. 373-86.

65. "Texas Land and Water Law . . .," Paper read at Texas State Historical Association meeting in Austin, Texas (March 8, 1975), $14 \mathrm{p}$.

66. McMillan, Henry W. "Water and Watercourses--Public Right of Fishery In Navigable Waterg Over Private Submerged Land," Texas Law Review, XII, No. 1 (December, 1933), 72-81.

67. McNeely, John G. and Ronald D. Lacewel1. "Demand Increasing for Texas' Water Resources," Texas Agricultural Progress, XXIII, No. 3 (Summer, 1977), 4-7.

68. Surface Water Development in Texas. TAES Bulletin No. 177. College Station: Texas Agricultural Experiment Station, May, 1977 .

69. Water Resource Uses and Issues in Texas. TAES BuIletin No. 1189. College Station: Texas Agricultural Experiment Station, August, 1978.

70. Makens, James C. Maken's Guide to U. S. Canoe Trails. Irving, Texas: Voyageur Publishing Co., 1971.

71. Manry v. Robison, 122 Tex 213, 56 Sw2d 438, Tex Sup Ct (1932).

72. Meyers, Charles J. and A. Dan Tarlock. Water Resource Management: A Casebook in Law and Public Policy. Mineola, N.Y.: The Foundation Press, Inc., 1971.

73. "Minimum Streamflows for Fish and Wildlife," Texas State Bar Section Report--Environmental Law, VII, No. 7 (May, 1977), p. 3.

74. Mitche11 v. Town of Refugio, 265 Sw2d 261, Tex Civ App (1954) Err. ref.

75. "Mitigation?," Texas Water Resources, II, No. 5 (June, 1976), 1-4.

76. MotI v. Boyd, 116 Tex 82, 286 SW 458, Tex Sup Ct (1926).

77. National Water Commission. Water Policies for the Future. Port Washington, N.Y.: Water Information Center, Inc., 1973.

78. Neuman, Michael T. Public Access to the Great Lakes: A Policy Study, 1976. Madison: Wisconsin Department of Natural Resources, Coastal Management Program, 1976. 
79. Nolen, Ben M. (ed.). Texas Rivers and Rapids. Humble, Texas: Nolen and Narramore, 1974.

80. , (ed.). Texas Rivers and Rapids, Volume I. Humble, Texas: Nolen and Narramore, 1972 .

81. (ed.). Texas Rivers and Rapids, Volume II. Humble, Texas: Nolen and Narramore, 1973.

82. Oklahoma v. Texas, 260 US 606, US Sup Ct (1923).

83. Owens, David $W$. Public Rights in Shoreline Recreation Areas: A Selectively Annotated Blbliography. Exchange Bibliography 894. Monticello, I11.: Council of Planning Librarians, 1975.

84. Peters, Clay E. "A National System of Wild and Scenic Rivers," Naturalist, XXVI, No. 1 (Spring, 1975), 28-31.

85. Price, Steve. "Run Silent, Run Cheap: Try Texas Fishing from a Canoe," The Texas Fisherman, II, No. 10 (February, 1975), 6-9.

86. "River Flow Information Available to Canoeists," Texas Parks and Wildlife, XXXVII, No. 7 (Ju1y, 1978), 20.

87. Roberts, Kenneth. "Title and Boundary Problems Relating to Riverbeds," Texas Law Review, XXXVI, No. 3 (February, 1958), 299-321.

88. Rules of the River. Austin: River Recreation Association of Texas, 1978.

89. St. Paul Fire \& Marine Ins. Co. v. Carroll, 106 SW2d 757, Tex Civ App (1937).

90. Schneider, Bil1. "Do Landowners Hassle Fishermen Illegally?," Western Outdoors, XXII, No. 6 (June, 1975), 32-33.

91. Scott, James $W$. and Ron Hyra. "Methods for Determining Instream Flow Requirements for Selected Recreational Activities in Small and Medium Sized Streams," Paper read at the 13th American Water Resources Association meeting, Tucson, Arizona (November, 1977), $23 \mathrm{p}$.

92. Selman v. Wolfe, 27 Tex 68, Tex Sup Ct (1863).

93. Simmons, Robert M. "Legal Aspects of River Recreation Management in the West," in River Recreation Management and Research. General Technical Publication NC-28. St. Paul, Minn.: USDA, Forest Service, North Central Forest Experiment Station, 1977, pp. 32-37.

94. Smith v. Godart, 295 SW 211, Tex Civ App (1927).

95. Spivey, Marvin. "Closed Beaches: How Far Will it Go?," The Texas Fisherman, VI, No. 3 (July, 1978), 2. 
96. Stankey, George H. "Recreational Geography: Its Evolution and Application to Problems of Wilderness Management," in Applications of Geographic Research: Viewpoints from Michigan State. Lansing: Michigan State University, 1977, pp. 75-87.

97. State V. Black Bros., 116 Tex 615, 297 SW 213, Tex Sup Ct (1927).

98. State v. Bradford, 121 Tex 515, 50 Sw2d 1065, Tex Sup Ct (1932).

99. State v. Grubstake Investment Assn., 117 Tex 53, 297 SW 202, Tex Sup Ct $(1927)$.

100. Stephensen V. Wood, 119 Tex 564, 34 Sw2d 246, Tex Sup Ct (1931).

101. - Stiles, Arthur A. "The Gradient Boundary--The LIne Between Texas and Oklahoma Along the Red River," Texas Law Review, XXX, No. 3 (January, 1952), 305-22.

102. Stone, Albert W. "Public Rights in Water Uses and Private Rights in Land Adjacent to Water," Chap. 3 in Robert E. Clark (ed.), Waters and Water Rights, Vo1.1. Indianapolis: The Allen Smith Company, 1967, pp. 177-279.

103. Stowers, Henry. "Canoes Gain in Popularity," The Texas Fisherman, V, No. 5 (September, 1977), 26.

104. Suggitt, Frank W. "Institutional Constraints in the Development of Recreational Resources in Texas," in Research on Texas Water and Recreational Resources. Departmental Information Report No. 7 . College Station: Texas A\&M University, Department of Agricultural Economics and Sociology, 1968, pp. 19-33.

105. "Sure Signs of a Reservoir," Texas Water Resources, IV, No. 5 (June, 1978), $1-4$.

106. Taylor Fishing Club v. Hammett, 88 SW2d 127, Tex Civ App (1935).

107. Templer, Otis W. "Geographical Aspects of Water Law in the Nueces River Basin, Texas," Unpublished Ph.D. Dissertation. University of California, Los Angeles, December, 1969.

108. Institutional Constraints and Conjunctive Management of Water Resources in West Texas. Water Resources Center Publication WRC-76-1. Lubbock: Texas Tech University, Water Resources Center, February, 1976.

109. "Institutional Constraints and Water Resources: Water Rights Adjudication in Texas," Rocky Mountain Social Science Journal, $\mathrm{X}$, No. 3 (October, 1973), 37-45.

110. "Texas Surface Water Law: The Legacy of the Past and Its Impact on Water Resource Management," Historical Geography, VIII, No. 1 (Spring, 1978), 11-20. 
111. Terry, Ross D. "Waters and Watercourses--Title to Stream Beds and Riparian Lands--Determinable Fees," Texas Law Review, XII, No. 4 (June, 1934) , 490-500.

112. "Texans Fight Proposed Rio Grande Park Plan," Lubbock Avalanche-Journal, (March 6, 1978), P. 6-A.

113. Texas Attorney General's Office. Attorney General Opinion S-107. Austin: Texas Attorney General, 1953.

114. Attorney General Opinion S-208. Austin: Texas Attorney Genera1, 1956 .

115. "Texas Ganoeing Grows in Popularity," Texas Parks and Wildlife, XXXV, No. 6 (June, 1977), $16 \mathrm{C}$.

116. Texas Parks and Wildlife Code. 2 vols. St. Paul, Minn.: West Pub1ishing Co., 1976.

117. Texas Parks and Wild11fe Department. An Analysis of Texas Waterways. Austin: The Department, 1973.

118. - Pathways and Paddleways: A Trails and Scenic Waterways Feasibility Study. Austin: The Department, August, 1971.

119. - Public Access to Fishing Waters of Texas, Region I. TP\&WD Inland Fisheries Series No. 1. Austin: The Department, 1970.

120. - Public Access to Fishing Waters of Texas, Region II. $\overline{T P \& W D}$ Inland Fisheries Series No. 2. Austin: The Department, 1970.

121. - Public Access to Fishing Waters of Texas, Region III. TP\&WD Inland Fisheries Series No. 3. Austin: The Department, 1970.

122. - Texas Outdoor Recreation P1an. 10 vols. Austin: The Department, 1975 .

123. - Texas Waterways: A Feasibility Report On a System of Wild, Scenic and Recreational Waterways in Texas. Austin: The Department, November, 1973.

124. Texas University, Bureau of Business Research. Canyon Reservoir, The Economic Growth of a Planned Recreation Area. Area Economic Survey No. 21. Austin: The Bureau, 1967.

125. Texas Water Code Annotated. 3 vols. St. Paul, Minn.: West Publishing Co., 1972 .

126. Texas Water Development Board, Donald B. Yarbrough (comp.). Laws and Programs Pertaining to Texas Land and Water Resources. Report No. 89. Austin: The Board, 1968. 
127. - Continuing Water Resource Planning and Development for

Texas. (Review Draft), 2 vols. Austin: The Board, 1977.

128. Texas Water Report. a) XXII, No. 44 (August 7, 1975); b) XXIII, No. I2 (January 8, 1976); c) XXIV, No. 6 (November 25, 1976); d) XXIV, No. 21 (March 17, 1977); e) XXIV, No. 22 (March 24, 1977); f) XXIV, No. 49 (September 29, 1977); g) XXV, No. 3 (November 10, 1977); h) XXV, No. 20 (March 9, 1978); 1) XXV, No. 36 (June 29, 1978); j) XXV, No. 39 (July 20, 1978); k) XxV, No. 45 (August 31, 1978).

129. Texas Water Rights Commission. Final Determination of Claims of Water Rights in the Upper Guadalupe River Segment of the Guadalupe River Basin. Austin: The Commission, 1977.

130. Tinsley, Russe11. "A River is Something Speeial, " The Texas Fisherman; III, No. 6 (October, 1975), 14-17.

131. Tri County Citizens Rights Organization v. Johnson, 498 Sw2d, Tex Civ App (1973).

132. Valmont Plantations v. Texas, $163 \mathrm{Tex} 381,355$ SW2d 502, Tex Sup Ct (1962).

133. Waite, G. Graham. A Four-State Comparative Analysis of Public Rights in Water. Madison: University of Wisconsin, School of Law, University Extension, 1967.

134. "Public Rights to Use and Have Access to Navigable Waters," Wisconsin Law Review, (July, 1958): 335-75.

135. "Water in Court," Texas Water Resources, III, No. 4 (May, 1977), 1-4.

136. "Water Rights and Their Incidents," Texas Jurisprudence 2d, Vol. LX. San Francisco: Bancroft-Whitney, Inc., 1964, pp. 339-41.

137. Welder v. State, 196 SW 869, Tex Civ App (1917).

138. "Who Owns This Land?," Texas Parks and Wildlife, XXXIV, No. I (January, 1976), 8-10.

139. Wilke, L. A. "Blanco River: The Stream with the Dams," The Texas Fisherman, III, No. 5 (September, 1975), 29.

140 . - "Fishing on the Guadalupe River," The Texas Fisherman, IV, No. 6 (October, 1976), 13.

141. "Pedernales: A Primitive Fishing Hole," The Texas Fisherman, III, No. 4 (August, 1975), 29.

142. "Sleeper Lakes on a Sleepy River," The Texas Fisherman, II, No. 1 (May, 1974), 30-31. 
